\title{
AVALIAÇÃO DOS DESEMPENHOS OPERACIONAL E ECONÔMICO DE SISTEMA DE COLHEITA SEMI-MECANIZADA EM CANA-DE-AÇÚCAR, COM E SEM QUEIMA PRÉVIA
}

\author{
CARLOS ANTONIO DA COSTA TILLMANN \\ Engenheiro Agrícola
}

Orientador: Prof. Dr. Marcos Milan

Dissertação apresentada à Escola Superior de Agricultura "Luiz de Queiroz", da Universidade de São Paulo, para obtenção do título de Mestre em Agronomia, Área de Concentração: Máquinas Agrícolas.

\section{PIRACICABA}

Estado de São Paulo - Brasil

Julho - 1994 
Ficha catalografica frefarada fiela befáa de Livros da

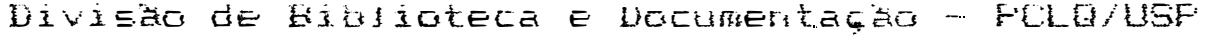

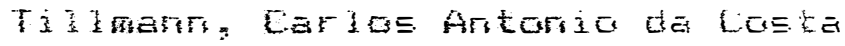

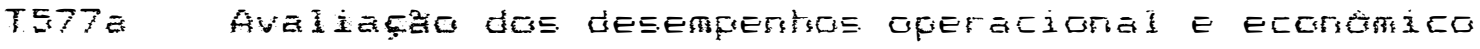
de Eistema de calbeita semi-mecanizada en cana-de-aç

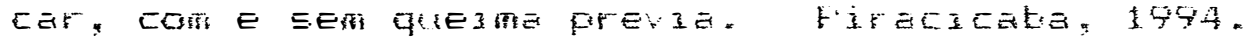
$131 \mathrm{Fe}$.

DisE. (NEStre) - ESALG

Eibliogratia.

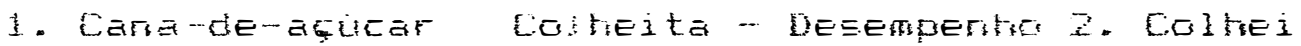
ta - Afralise ecoromica I. Escerla Suferior de figricultu

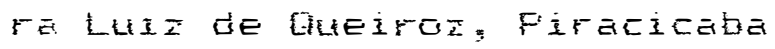

CDI $\quad 35.61$ 
AVALIAÇÃO DOS DESEMPENHȮS OPERACIONAL E ECONÔMICO DE SISTEMA DE COLHEITA SEMI-MECANIZADA EM CANA-DE-AÇÚCAR, COM E SEM QUEIMA PRÉVIA

\section{CARLOS ANTONIO DA COSTA TILLMANN}

Aprovado em: 12/09/94

Comissão Julgadora:

Prof. Dr. Marcos Milan

ESALQ/USP

Prof. Dr. Carlos Antônio Gamero

FCA/UNESP/BOTUCATU

Prof. Dr. Luiz Carlos Beduschi

FCAV/UNESP/JABOTICABAL

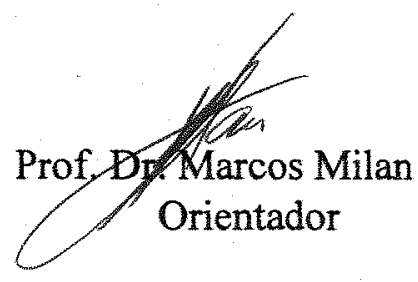


Á Minha Esposa Angela e Filhos Patrícia e Eduardo Dedico. 


\section{AGRADECIMENTOS}

Ao Professor Marcos Milan, Orientador e Amigo, pelo estímulo, apoio e sugestões.

Ao Professor Tomaz Caetano Ripoli, pela amizade e orientação inicial nos primeiros passos da realização deste trabalho.

Ao Professor Humberto de Campos, do Departamento de Matemática e Estatística, pelo precioso apoio no equacionamento do delineamento da análise estatística.

Ao colega Eng ${ }^{\circ} \cdot \mathrm{Agr}^{\circ}$. Renato Kraide Soffner pelas sugestões e colaboração.

Aos Professores e Colegas do Setor de Mecânica e Máquinas Agrícolas do Departamento de Engenharia Rural da ESALQ/USP, pelos valiosos conselhos na elaboração deste.

Á Usina Costa Pinto S.A. - Açúcar e Álcool, pela oportunidade de realização dos trabalhos experimentais em campo.

Á Universidade Federal de Pelotas, pela concessão do afastamento das atividades profissionais para realização do Curso.

Ao $\mathrm{CNPq}$, pelo apoio financeiro durante o Curso.

Á todos que de forma direta ou indiretamente contribuiram para a realização deste trabalho. 
SUMÁRIO

Páginas

LISTA DE FIGURAS . . . . . . . . . . . . . . . . xix

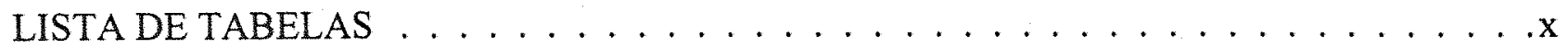

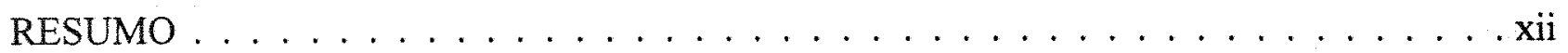

SUMMARY . . . . . . . . . . . . . . . . . . xiv

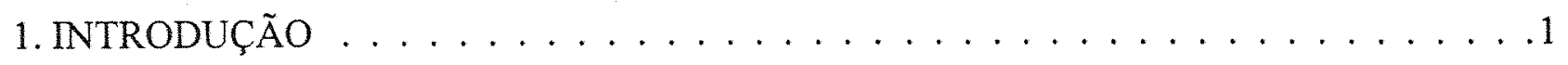

2. REVISÃO BIBLIOGRÁFICA . . . . . . . . . . . . 3

2.1. Considerações Gerais. . . . . . . . . . . . . . . . . . 3

2.2. A Prática da Queima em Cana-de-Açúcar . . . . . . . . . . . . . 4

2.3. o Corte Manual de Cana-de-Açúcar. . . . . . . . . . . . . . . . . . 14

2.4. Carregamento e Qualidade da Matéria-Prima . . . . . . . . . . 16

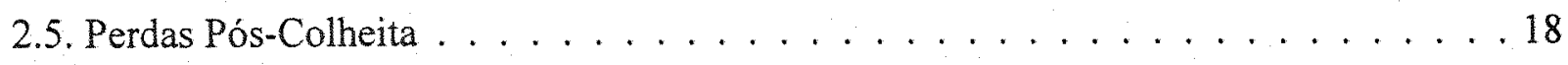

2.6. Potencial Energético da Cana-de-Açúcar . . . . . . . . . . . . . 20

2.7. Custos Operacionais . . . . . . . . . . . . . . . 26

3. MATERIAL E MÉTODOS . . . . . . . . . . . . . . . 28

3.1. Fundamentos da Hipótese de Trabalho $\ldots \ldots \ldots \ldots 28$

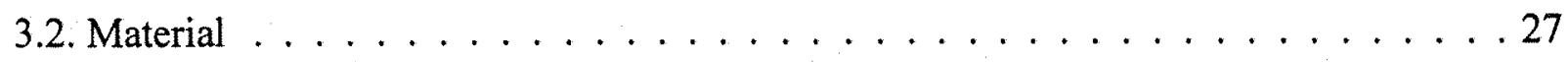

3.2.1. Material de Campo. . . . . . . . . . . . . . . . . . . 29 


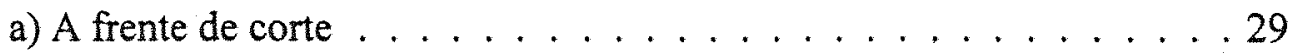

b) Variedades de cana-de-açúcar . . . . . . . . . . . . . . . . 29

c) Tipos de solos. . . . . . . . . . . . . . . . . . . . . 29

d) Conjuntos mecanizados . . . . . . . . . . . . 30

e) Equipamentos de mesuração dimensional . . . . . . . . . . . 30

f) Equipamentos de mensuração ponderal e temporal. . . . . . . . . 30

g) Equipamentos de aplicação geral. . . . . . . . . . . . . 31

3.2.2. Material de Laboratório . . . . . . . . . . . . . 31

a) Máquinas e equipamentos para determinação da anallise tecnológica e de impurezas da matéria-prima . . . . . . . . . . . . 31

b) Equipamentos para determinação do poder calorífico e grau de umidade das frações componentes da matéria-prima . . . . . . . . 32

3.3. Métodos . . . . . . . . . . . . . . . . . 32

3.3.1. Determinações de Campo . . . . . . . . . . . . . . . . . 32

a) Porte do canavial $\ldots \ldots \ldots \ldots \ldots \ldots$

b) Caracterização dimensional e ponderal das plantas e suas frações . . . 33

c) Capacidade de campo operacional do corte manual . . . . . . . 33

d) Capacidade de campo operacional do carregamento e transporte $\ldots 34$

e) Determinação do grau de umidade e granulometria do solo . . . . . 35

f) Determinações pós-colheita . . . . . . . . . . . . . . . 36

3.3.2. Determinações Laboratoriais. . . . . . . . . . . . . . . . 36

a) Caracterização tecnológica de impurezas minerais e vegetais da matéria-prima. . . . . . . . . . . . 36 
b) Determinação do grau de umidade, poder calorífico superior, inferior e útil das frações das plantas. . . . . . . . . . . . . 37

c) Determinação do grau de umidade e granulometria do solo . . . . . 38

3.3.3. Avaliação de Desempenho Econômico dos Sistemas . . . . . . . . . . . 39

3.3.4. Análise Estatística $\ldots \ldots \ldots \ldots \ldots \ldots$. . . . . . . . . . . . .

4. RESULTADOS E DISCUSSAO . . . . . . . . . . . . . . . . . . 42

4.1. Caracterização do Canavial . . . . . . . . . . . . . . . . . 42

4.1.1. Porte e Caracterização Dimensional do Canavial . . . . . . . . . . . . 42

4.1.2. Caracterização Ponderal do Canavial . . . . . . . . . . . 43

4.2. Capacidade de Campo Operacional do Corte Manual . . . . . . . . . . . . 46

4.3. Capacidade de Campo Operacional do Carregamento e Transporte. . . . . . . . . . 49

4.3.1. Carregamento. . . . . . . . . . . . . . . . . .49

4.3.2. Transporte . . . . . . . . . . . . . . . . . . .

4.4. Análise de Pós-Colheita . . . . . . . . . . . . . . . . . . . 54

4.5. Análise de Impurezas na Matéria-Prima . . . . . . . . . . . . . . . . 57

4.6. Análise do Teor de Bagaço na Matéria-Prima . . . . . . . . . . . . 60 60

4.7. Determinação do Potencial Energético do Canavial. . . . . . . . . . . . 61

4.8. Avaliação de Desempenho Econômico dos Sistemas . . . . . . . . . . . . . 65

4.9. Considerações Finais. . . . . . . . . . . . . . . . . . 68

5. CONCLUSÕES. . . . . . . . . . . . . . . . . . . . . . . 69 


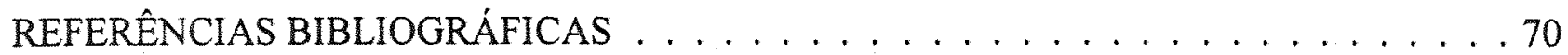

APÊNDICE 1: Dados originais de campo, laboratórios e econômicos . . . . . . . . . . . . 79

APÊNDICE 2: Dados transformados . . . . . . . . . . . . . . . . . 101

APÊNDICE 3: Memória de cálculo. . . . . . . . . . . . . . . . . . . . . . . . 109 


\section{LISTA DE FIGURAS}

Figuras

Páginas

1 Distribuição percentual da massa vegetal (média) sobre a quantidade total colhida para as áreas A e B nas condições de cana crua e queimada. . . . . . 45

2 Capacidade de campo operacional dos cortadores de cana-de-açúcar para as para as áreas $\mathrm{A}$ e $\mathrm{B}$ nas condições de cana crua e queimada . . . . . . 4 48

3 Capacidade de campo operacional de carregamento em th para as áreas A e B nas condições de cana crua e queimada . . . . . . . . . . . 51

4 Perdas de pós-colheita no campo em percentagem relativas a produtividade para as áreas A e B nas condições de cana crua e queimada . . . . . . . . . . . . . . . . 56

5 Composição média da carga transportada em toneladas para as condições de cana crua e queimada nas áreas A e B . . . . . . . . . . . 59

6 Potencial energético, em percentagem, das frações componentes do palhiço: poneiros (PO); folhas verdes (FV) e palhas (PA). Os valores referem-se a média para as áreas em cana crua e queimada . . . . . . . 64 


\section{LISTA DE TABELAS}

Tabelas

Páginas

1 Valores médios que compõem as condições físicas do canavial para as

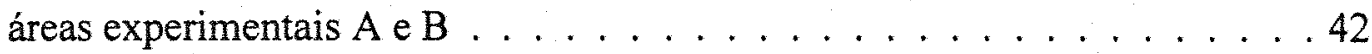

2 Quantidades médias estimadas de massas de colmos (MCO); ponteiros (MPO); follhas verdes (MFV) e palhas (PA) para as áreas experimentais, nas condições de cana crua e queimada . . . . . . . . . . . 43

3 Valores percentuais obtidos para índice de palhiço (IP) nas áreas experimentais A e B, para as condições de cana crua e queimada . . . . . . 46

4 Capacidade de campo operacional do corte manual: Valores médios em toneladas/homem.dia para as condições de cana crua e queimada nas áreas experimentais. . . . . . . . . . . . . . 447

5 Valores médios referentes a capacidade operacional do corte manual de cana-de-açúcar . . . . . . . . . . . . . . . . . . . . . . 49

6 Capacidade operacional do carregamento da matéria-prima recolhia nas áreas experimentais, para as condições de cana crua e queimada . . . . . . 50

7 Valores de velocidade fornecida e calculada para os veículos de transporte da matéria-prima, nas condições de cana crua e queimada . . . . .53

8 Capacidade operacional do transporte da matéria-prima recolhida nas áreas experimentais, para as condições de cana crua e queimada . . . . . .54

9 Quantificação das perdas pós-colheita de colmos (CO), frações de colmos (FCO) e palhiço (PP), nas áreas experimentais, para as condições de cana

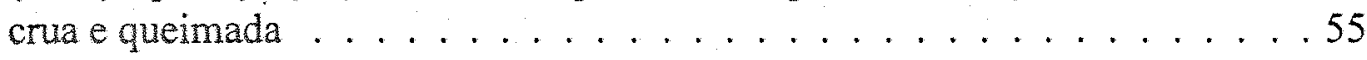

11 Resultados médios da massa de: matéria prima amostrada pela sonda (MAS) e percentagens de matéria estranha vegetal (MEV), mineral (MEM) e colmos (MC) nas unidades de transportes para as condições de cana crua e queimada . . . . . . . . . . . . . . 58 
11 Resultados médios para o teor de bagaço obtido a partir das amostras das unidades de transportes para as condições de cana crua e queimada. . . . . .60

12 Resultados médios de poder calorífico - $\mathrm{kcal} / \mathrm{kg}$, superior (PCS), inferior $(\mathrm{PCI})$ e útil $(\mathrm{PCU})$ do palhiço obtido nas áreas $\mathrm{A}$ e B, para as condições de cana crua e queimada . . . . . . . . . . . . . . . . 66 62

13 Determinação do potencial energético do palhiço (ponteiro - PO; folhas verdes - FV e palhas - PA) - PEP (Mcal/ha) para as áreas experimentais nas condições de cana crua e queimada . . . . . . . . . . 63

14 Valores médios de Renda Líquida Estimada (RLE) em US\$/t obtidos para as condições de cana crua e queimada nas áreas experimentais A e B. . . . . 66 


\title{
AVALIAÇÃO DOS DESEMPENHOS OPERACIONAL E ECONÔMICO DE SISTEMA DE COLHEITA SEMI-MECANIZADA EM CANA-DE-AÇÚCAR COM E SEM QUEIMA PREVIA
}

\author{
Autor: Carlos Antonio da Costa Tillmann \\ Orientador: Prof. Dr. Marcos Milan
}

\section{RESUMO}

A expansão da lavoura canavieira no Brasil, hoje com aproximadamente 4 milhões de hectares, possibilita uma intensa atividade sócio-econômica geradora de divisas para as regiões produtoras de açúcar e álcool.

A atividade tradicional de colheita da cana-de-açúcar adota a queima como forma de realizar a pré-limpeza nos canaviais. Essa prática entretanto tem sido considerada como excessivamente prejudicial à qualidade de vida sob os aspectos ambientais e energéticos envolvidos.

A hipótese sobre a qual este estudo foi realizado, é de que, apesar dos aumentos nos custos operacionais das operações de corte, carregamento e transporte da cana colhida sem queima prévia, pode haver vantagem econômica na adoção do sistema, caso se verifique a comercialização do bagaço liberado e o aproveitamento dos resíduos disponíveis pós-colheita.

Para tanto, avaliou-se comparativamente o desempenho operacional e econômico de sistema de colheita semi-mecanizada de cana-de-açúcar com e sem queima prévia. $O$ experimento foi realizado em duas áreas da Usina Costa Pinto S.A., no município de Piracicaba, SP utilizando-se as variedades SP 711406 e SP 716163 implantadas em canaviais de $2^{\circ}$ e $3^{\circ}$ cortes, respectivamente.

Pelos resultados obtidos conclui-se que, tanto o desempenho operacional como o desempenho econômico do sistema de colheita para a condição de cana sem queima prévia, 
foram relativamente inferiores aos verificados para a condição de cana queimada. Entretanto, considerando o aproveitamento racional do potencial energético equivalente disponível na biomassa vegetal caracterizada pelo palhiço, há evidências de benefícios sob os aspectos ambientais e energéticos que ocorrerão com a adoção do sistema que colhe cana crua. 


\title{
EVALUATION OF THE OPERATIONAL AND ECONOMICAL PERFORMANCE OF A HARVEST SYSTEM FOR GREEN AND BURNED SUGAR CANE
}

\author{
Author: Carlos Antonio da Costa Tillmann
}

Adviser: Prof. Dr. Marcos Milan

\section{SUMMARY}

The expansion of the sugar cane area in Brazil, nowadays about 4 million hectares are cultivated, improved the social and economical aspects of the producer regions.

The traditional way to harvest the sugar cane is using fire as a way to provide best conditions for the manual cut; on the other hand, the use of fire has influences on the environment and energetics aspects.

The hypothesis of this work is that harvesting the sugar cane as green cane can be more expensive, but increasing the residual quantities may give an economic advantage, using as a source of energy.

In this work a comparison between the two harvest systems - green and burned was performed. The work was done in two areas, that belong to Costa Pinto Sugar Mill, located at Piracicaba, SP, using two varieties: SP 711406 and SP 716163.

The results showed that operational and economic performance of the green cane inferior than the burned. The advantage of this system is the use of the residual as an energetic source, improving the environmental conditions, avoiding the hazardous effects of the fire. 


\section{INTRODUÇÃO}

O Brasil se destaca mundialmente como um dos maiores produtores de cana-de-açúcar. Durante a safra 91/92, em uma área colhida de, aproximadamente, 4,2 milhões de hectares, produziu-se cerca de 260 milhões de toneladas de cana-de-açúcar para fabricação de álcool e açúcar. Somente o Estado de São Paulo teve uma participação de 2,0 milhões de hectares, com uma produção de 154 milhões de toneladas, apresentando uma produtividade agrícola média de 77 toneladas por hectare (AEB, 1992 e AEESP, 1992).

Com essa quantidade de matéria-prima disponível à indústria sucroalcooleira, observa-se empenho por parte de usinas, bem como de instituições de pesquisas do Brasil, em desenvolver programas de pesquisas voltados a busca de novas fontes alternativas de energia, através do aproveitamento do potencial energético disponível na biomassa vegetal excedente desses canaviais, resguardando interesses voltados a aspectos sócio-econômicos e também diretamente ligados à preservação do meio ambiente.

Tradicionalmente, adota-se a queima de canaviais, como prática de pré-colheita. A bibliografia especializada apresenta os mais variados resultados referentes aos prós e contras a cerca de tal prática, quer seja do ponto-de-vista da qualidade da matéria-prima, quer dos custos da operação de colheita, ou dos prejuízos à fertilidade do solo ou ainda das questões relacionadas à agressão do meio ambiente. Além desses fatores, há a considerar ainda, o efeito da condição do canavial (queimado ou não), no desempenho operacional dos trabalhadores braçais.

O canavial não queimado Chinui considerávelmente a capacidade operacional da mão-de-obra, devido ao grande volume de massa verde existente (folhas verdes, secas e ponteiros), caracterizado pelo palhiço e que deve ser separado dos colmos na operação de 
colheita, provocando um aumento do esforço físico por parte dos trabalhadores, refletindo na sua capacidade de trabalho diária.

O presente trabalho tem por objetivo avaliar o desempenho operacional e economico de um sistema de colheita semi-mecanizado caracterizado pelas seguintes atividades: corte manual, carregamento mecânico e transporte mecânico em canaviais com e sem queima de pré-colheita. 


\section{REVISÃO BIBLIOGRÁFICA}

\subsection{Considerações Gerais}

No Brasil, nos últimos anos, vêm ocorrendo mudanças gradativas na operação de corte da cana-de-açúcar. Ao se analisar esse processo na década de 50, observa-se que o corte era realizado em condições de cana crua com despalha manual. Os colmos eram dispostos em eitos formados a partir de três linhas de plantio, no sentido longitudinal ao deslocamento da frente de corte, para facilitar seu carregamento que também se processava manualmente. Esse sistema trazia como vantagem a transferência ao setor industrial, de uma matéria-prima praticamente isenta de impurezas, conforme relata PEREIRA (1983).

O mesmo autor, comenta ainda que na década de 60 , o setor agroindustrial de cana-de-açúcar se deparou com as primeiras dificuldades de escasses de mão-de-obra, o que levou a se adaptar a nova situação através de mudanças radicais. Inicialmente elas ocorreram no sistema de carregamento da matéria-prima às unidades transportadoras, o qual passou a ser mecânico, alterando também o processo operacional de colheita na formação dos eitos, passando de três para cinco linhas de plantio, dispostas transversalmente à posição dos sulcos. No corte, ocorreu a substituição da despalha manual pela de queima prévia dos canaviais, promovendo assim melhor limpeza facilitando o corte aos cortadores, além de beneficiar a capacidade diária, que de 1 a 2 toneladas passou para 4 a 6 toneladas, ocasionando com isso, melhoria em sua remuneração.

PEREIRA (1983), descreve que com a criação do PROALCOOL em 1975 o setor sofreu considerável impulso, estimulando um rápido crescimento, de forma a atender a demanda quantitativa imposta ao sistema. Tal fato gerou um rápido aumento na área plantada de forma desordenada, ao ponto de comprometer a qualidade das operações, tanto a nível de campo, como industrial. No setor agrícola, o uso indiscriminado de máquinas e veículos pesados, aliado ao tráfego intenso, provocou excessiva compactação dos solos e 
perdas decorrentes das ineficientes operações de corte e carregamento. $\mathrm{Na}$ indústria, houve um aumento elevado nos índices de impurezas aderidas à matéria-prima.

A importância econômica da agroindústria açucareira pode ser avaliada, segundo dados do Anuário Estatístico Brasileiro -IBGE (1992). Na safra de 91/92, o Brasil possuia uma área de aproximadamente 4,2 milhões de hectares, produzindo cerca de 260 milhões de toneladas de cana-de-açúcar para fabricação de álcool e açúcar, sendo apenas superada pelas áreas cultivadas com milho (13,1 x $106 \mathrm{ha})$, soja $(9,6 \times 106 \mathrm{ha})$ e feijão $(5,4 \times 106 \mathrm{ha})$.

Somente o Estado de São Paulo tem uma participação de aproximadamente 2 milhões de hectares para uma produção de 150 milhões de toneladas de cana-de-açúcar (Anuário Estatístico do Estado de São Paulo, 1991). Segundo relatado por BERTELLI (1992), o complexo sucroalcooleiro nacional é constituído por 348 unidades industriais (168 usinas e 180 destilarias), das quais 245 operam na região Centro-Sul e 103 na região Norte-Nordeste. Somente no Estado de São Paulo estão instalads 206 unidades industriais (73 usinas anexas ás destilarias e 133 destilarias autônomas).

\subsection{A prática da queima em cana-de-açúcar}

A prática da queima prévia em canaviais, segundo descrevem RIPOLI \& MIALHE (1987), caracteriza-se por ser uma eficiente operação de limpeza do canavial, influindo positivamente no desempenho da operação de corte manual, reduzindo o esforço físico dos trabalhadores aumentando a capacidade de trabalho, reduz a incidência de animais peçonhentos e aumenta a disponibilidade de mão-de-obra. Sob este aspecto, FURLANI NETO (1991) comenta que é prática tradicional na região Centro-Sul do país, a queima dos canaviais para posterior corte e carregamento, e que algumas variedades, favorecem a ação do fogo na eliminação de folhas e palhas indesejáveis do canavial, auxiliando no aumento do desempenho operacional do corte.

Para canaviais onde realizou-se o corte manual da cana crua, sem queima prévia, 
os principais componentes constituintes das impurezas totais são formados pela materia estranha vegetal, folhas verdes e secas e quantidades mínimas de pontas e brotos e a matéria estranha mineral, quantidade de terra aderida a matéria-prima durante o carregamento mecânico, que pode ser aumentada se o carregamento não for executado de forma cuidadosa, elevando o índice de impurezas.

Com relação aos aspectos favoráveis e desfavoráveis da prática da queima de pré-colheita, DELGADO (1985), relacionou os mais relevantes como sendo:

a) de caráter agronômico: - a queima destrói os inimigos naturais da broca da cana-de-açúcar; - facilita as operações de preparo do solo e de cultivo; - aumenta o teor de cinzas do solo; - facilita a operação de corte tanto manual como mecanizado; - a palha pode ser incorporada ao solo aumentando seu potencial de matéria orgânica.

b) de caráter industrial: - ficam vinculados ao maior ou menor tempo de exposição após a queima, a dificuldade na conservação e purificação dos caldos; - aumento aparente dos teores de brix, sacarose e de fibra em porcentagem, devido ao ressecamento dos colmos; - aumento da taxa de microorganismos pela exudação do caldo nos colmos, predispondo-os a deterioração.

c) de caráter econômico e operacional: - a prática da queima torna a operação de colheita mais barata e fácil tanto no processo de corte mecanizado como no corte manual. Neste último, o custo chega a ser cerca de 30 a $50 \%$ maior em cana na palha; - maiores prejuizos ocorrem em canaviais que foram préviamente queimados e cujos colmos demoram a ser colhidos.

d) de caráter energético: - as queimadas através da eliminação das palhas contribui para perder-se um percentual de matéria bruta estimado em cerca de $30 \%$ do seu peso ou de $15 \%$ correspondente a matéria seca, tornando-se claro que, caso fosse aproveitada nas caldeiras, com vista a produção de vapor, poderia ser excelente fonte geradora de energia. 
COSTA FILHO (1979), comenta que o processo de queima dos canaviais deve ser feito por equipes especializadas e treinadas, observando normas de segurança especificas bem como devem ser utilizados equipamentos próprios. $\mathrm{O}$ autor comenta que a atividade de queima dos canaviais, não traz prejuízos ao solo, e garante um aumento no desempenho do corte, o que se traduz em maior disponibilidade da mão-de-obra, e permite ainda a restituição de boa quantidade de palhiço proveniente dos ponteiros que não foram queimados.

STUPIELLO (1989), destaca alguns aspectos ligados à qualidade da matéria-prima, tendo em vista a problemática da queima de cana e à eficiência técnica de despalha. Compara a qualidade do caldo obtido em canaviais que foram queimados em horários denominados "a quente" (12 às 16 horas) e "a frio" (19 às 7 horas). Verificou que a queima realizada no periodo das 19 às 7 horas, "a frio" proporcionou os melhores parâmetros para avaliação tecnológica da matéria-prima. Quanto aos tipos de deterioração existentes, o autor classifica em: a) microbiológicos: dizem respeito às perdas de açúcares devido a atividade microbiana, cuja inoculação se deve às rachaduras dos colmos, provocadas pelo fogo; b) tecnológicos: quando as perdas de açúcares ocorrem por exudação e aumento da porcentagem de fibra da cana; c) fisiológicos: quando ocorrem perdas de açúcares, usados para reativar as atividades fisiológicas da planta, em função do tempo de exposição da planta no solo após a queimada.

RIPOLI \& PARANHOS (1987), conduzindo estudos sobre a qualidade da matéria-prima obtida de canaviais colhidos sem queima prévia, destacam que canas cortadas maduras, limpas e processadas o mais rápido possível, garantem condições ideais para a indústria. Entretanto, os autores comentam que a necessidade de antecipar uma limpeza parcial dos canaviais, facilitando as operações de corte, tornou a queima prévia uma operação obrigatória à colheita, e que tal prática, dependendo das condições climáticas, pode reduzir de 60 a $90 \%$ a quantidade de matéria estranha vegetal contida junto à matéria-prima colhida. 
RIPOLI (1988) relata uma série de incovenientes provocados pela prática da queima prévia que antecede a colheita em canaviais, apesar de consagrada pelos reflexos econômicos que traz a curto prazo. $O$ autor destaca os seguintes incovenientes: poluição ambiental; riscos de incêndios em outras áreas agrícolas ou matas; danificação as redes de transmissão de energia elétrica; dificuldade na implantação de sistemas de controle biológico de pragas; perda de sacarose através da exudação dos colmos, o que por sua vez, eleva os teores de matéria estranha mineral durante o carregamento; provoca um disperdício, em média, de 10 tha de massa vegetal que poderia ser incorporada ao solo melhorando suas propriedades físico-químicas ou mesmo ser utilizada como fonte energética na agroindústria.

KIRCHHOFF (1992) comenta que as queimadas existentes no Brasil, como as de vegetação rasteira que ocorrem na beira de estradas; as de palha da cana-de-açúcar que antecede a colheita e as que acontecem no cerrado, contribuem, indiretamente, para a mulltiplicação do efeito estufa, através da emissão de gases tóxicos, como óxido nitroso (N2O) e metano (CH4), bem como a destruição da camada de ozônio (O3) na atmosfera a partir do monóxido de carbono (CO). Além disso, afirma que as queimadas em desmatamentos e desflorestamentos que ocorrem na região amazônica contribuem diretamente para a intensificação do efeito estufa.

BASSINELLO et alii (s.d.), listam possiveis vantagens e desvantagens da colheita de cana-de-açúcar sem queima prévia. A presença da palha e palmito (restos de cultura), que permanecem no campo, podem propiciar as seguintes vantagens:

- maior possibilidade de manutenção da umidade no solo;

- controle de plantas daninhas sem a utilização de herbicidas ou diminuição na quantidade;

- melhor controle de erosão através da proteção do solo contra o impacto das gotas de chuva;

- aumento do teor de matéria orgânica do solo através da adoção desta técnica por 
vários anos;

- redução na população de nematóides nocivos à cana-de-açúcar, através do acréscimo da população de nematóides predadores e de microorganismos resultantes do aumento de matéria orgânica do solo;

- possibilidade de melhorar o aproveitamento da cana-de-açúcar, sob o ponto de vista energético (biomassa) levando-se toda a fonte de energia para a indústria;

- melhoria da qualidade da matéria-prima entregue para a industrialização;

- nas micro e mini-destilarias, que exigem baixas tonelagens diárias de matéria-prima, dificultando a queima de talhões inteiros de cana, a adoção da prática da colheita da cana crua, iria beneficiar o processo, além de permitir utilização dos ponteiros para alimentação animal;

- redução da poluição atmosférica provocada pela queima da cana.

Como desvantagens BASSINELLO et al (s.d.) citam:

- dificuldade de se contar com mão-de-obra para a adoção da técnica e resistência do próprio cortador em executá-la;

- rendimento do corte mais baixo, tanto o manual como o mecânico, implicando em maiores custos de produção;

- aumento de impurezas vegetais e minerais junto à matéria-prima;

- tendência de apresentar o corte basal mais elevado, provocando perdas de matéria-prima e prejudicando a brotação das soqueiras;

Os restos culturais no campo, segundo os citados autores, resultam em:

- dificuldades para brotação de soqueira, advinda da menor temperatura do solo e do sombreamento, dependendo do sistema adotado;

- maior foco de infestação para alojamento das pragas;

- impossibilidade de utilização dos implementos tradicionais nos tratos culturais de adubação e cultivo (subsolagem);

- necessidade de maior quantidade de nitrogênio na adubação de soqueira com a 
finalidade de suprir a parte imobilizada na decomposição da palha e aplicação, no plantio, de todo o fósforo exigido para o ciclo da cultura;

- perigo de fogo acidental no período da entre safra e durante a colheita;

- maior velocidade de deterioração (ataque de pragas) da cana crua em relação à cana queimada, após o corte;

- cuidado na escolha de variedades apropriadas (despalha fácil, com menor problema de doenças e broca);

- aumento na necessidade de transporte pela empresa;

- aumento no teor de fibra e, consequentemente, redução da extração do caldo pelas moendas;

- colhedoras de cana picada ou cana inteira foram, basicamente desenvolvidas para o corte de canas queimadas, com raras exceções;

- diminuição da velocidade de deslocamento da colhedora com aumentos do consumo operacional e custo final;

- aumento da incidência de acidentes de trabalho no corte de cana crua pelo uso do facão;

- na cana crua há maior incidência de animais peçonhentos (cobras, aranhas) no momento do corte, provocando sérios acidentes;

- aumento do ataque de broca (D. saccharalis) e de cigarrinhas da raiz (M. fimbriolata).

* RIPOLI \& VILLANOVA (1992) em artigo técnico relatam que as implicações da colheita de cana crua caracterizam-se em evitar um desperdício de energia produzido pela queima do palhiço (pontas, folhas verdes e palha) da cana-de-açúcar, o qual representa em média $32,5 \%$ da biomassa produzida por um canavial. Os autores citam algumas vantagens e desvantagens advindas da colheita de cana crua:

a) sob o ponto de vista agronômico, quando o palhiço decorrente desse processo permanece sobre o terreno: - diminuição ou até eliminação do uso de herbicidas; - aumento 
e manutenção do grau de umidade do solo; - eficiente mecanismo de controle de erosão; aumento da quantidade de matéria orgânica no solo; - redução da população de nematóides nocivos; - não destroi os inimigos naturais da broca.

b) sob o ponto de vista industrial, obter-se-ão reflexos positivos em termos de menores perdas de sacarose, diminuição dos problemas de tratamento de água de lavagem e do aproveitamento parcial do palhiço, associado ao bagaço para co-geração de energia elétrica.

As desvantagens que podem decorrer desse sistema de colheita: - aumento do esforço fisico dos trabalhadores braçais; - aumento no riscos de acidentes ocupacionais; redução no desempenho operacional desses trabalhadores com implicação direta no aumento marcante dos custos da tonelada cortada; - aumento na quantidade de matéria estranha vegetal recebida pela usina; - aumento no volume diário de matéria-prima esmagada; - aumento nas perdas ocasionadas por corte basal mais elevado (manual ou mecânico); - maior foco de infestações de pragas e doenças; - exigirá modificações em equipamentos de cultivo e adubação nitrogenada; e - grandes riscos de incendios acidentais ou propositais durante todo o ano.

RUIZ \& OROSCO (1992), relatam sobre a adoção do sistema cubano de colheita de cana crua a partir dos anos 80 , em face aos problemas causados pelas queimadas, as quais provocavam diminuição significativa nos rendimentos agrícolas e industriais, danificações aos solos e uma crescente contaminação ambiental.

Os sistemas de colheita adotados atualmente são semi-mecanizado (corte manual e carregamento mecânico) e mecanizado (colhedoras). Os autores comentam que a colheita no País, é realizada totalmente na condição de cana crua, sendo $75 \%$ mecanizado e $25 \%$ semi-mecanizado que é realizado em áreas de relêvo mais acidentado.

Para ambos os sistemas de colheita a qualidade da matéria-prima é melhorada por um processo de limpeza que sucede a colheita nas estações de beneficiamento da cana crua, elevando-se tanto a produtividade dos cortadores como melhora a matéria-prima. Os autores 
apresentam ainda algumas vantagens decorrentes da colheita de cana crua: - eliminação total das queimadas e seus efeitos nocivos causados a agricultura e ao meio ambiente; possibilidade de introduzir-se diferentes métodos de colheitas devido as estações de beneficiamento; - a qualidade da matéria-prima apresenta índices inferiores a $5 \%$ de impurezas; - utilização dos resíduos de colheita em diferentes aplicações; - aplicação de diferentes métodos de planejamento e diagnósticos que caracterizam confiabilidade no sistema; e - flexibilidade e versatilidade para diferentes condições agrícolas que permitam o desenvolvimento de uma agricultura natural sustentável.

CHURCHWARD \& POULSEN (1988) citam os benefícios considerados com a colheita de cana crua, especificamente os aspectos agronômicos pela manutenção dos resíduos provenientes da colheita sobre o solo, como conservação da umidade, controle de crescimento do mato, economia no sistema de cultivo, perfilhamento e brotação das soqueiras, além de permitir o tráfego sem prejuizos ao solo.

Sobre os efeitos da queima do ponto de vista das perdas de açúcar e energia, PAYNE (1986) conclui que esta pode implicar em redução de até $50 \%$ da biomassa da planta bem como reduções não desprezíveis no teor de sacarose.

NOA (1992) relata a importância da recuperação da biomassa associada às folhas e palhas, obtida através da colheita mecanizada de cana crua em Cuba. $\mathrm{O}$ autor informa que a colheita de cana crua chega a representar $90 \%$ das áreas cultivadas, sendo $74 \%$ das áreas com colheita mecanizada. Uma parte da palha fica no campo permitindo a conservação da umidade, reposição de nutrientes e redução do uso de herbicidas. A outra parte é recuperada e empregada como combustível em caldeiras, na produção de bio-fertilizantes ou como alimento para o gado. Os valores porcentuais das pontas e folhas possuem a seguinte composição em peso: matéria seca $=26,00$; açúcares totais $=2,18$; sacarose $=0$; fibras $=$ 19,$80 ;$ cinzas $=2,31 ;$ água $=74,00$ e outros componentes $=2,43$.

Estudando o processamento de cana sem desponte, BELLODI (1988) faz referência ao conceito de cana integral, como a cana crua colhida com toda palhada, palmito e folhas 
verdes, geralmente mecanizada e cana sem desponte, cana queimada colhida com palmito e folhas verdes parcialmente cortadas ou não e com restos de palhaça, geralmente manual . ou mecanizada.

O autor comenta que a prática da queima para reduzir a palhada é feita em horários impróprios, geralmente durante o dia, reduzindo sensivelmente o resíduo vegetal e incorrendo num problema que é a exudação dos colmos, o qual contribui à ocorrência de perdas no processo industrial. Os valores encontrados para porcentagens de impurezas foram sem desponte 8,1 e 1,6 com desponte 4,2 e 0,7 para as impurezas vegetais e minerais respectivamente. $\mathrm{O}$ autor conclui que no processamento da cana sem desponte ocorre um aumento nas impurezas minerais contribuindo para o desgaste dos equipamentos, pois a moagem da cana nestas condições só se justifica quando há indisponibilidade de mão-de-obra agrícola e mesmo assim a colheita deve ser criteriosa para evitar o excesso de resíduos.

- Com o objetivo de avaliar o efeito da moagem de cana crua e queimada com e sem desponte como matéria-prima para fabricação de açúcar, álcool e energia, SILVA \& SILVA JUNIOR (1982) constataram que o brix, pol e pureza foram significativamente menores para canas com pontas em relação a despontadas, apresentando valores de fibra e bagaço na porcentagem de cana significativamente mais elevados nas canas com pontas.

* A cana com ponta e total, considerada folhas e ponteiros, apresentaram qualidade tecnológica inferior à cana despontada, embora a com ponta registrou maiores quantidades de açúcar e álcool por hectare. Pela análise econômica em relação aos custos de produção agrícola, incluíndo corte, carregamento e transporte para canas com e sem desponte, os autores observaram que as sem desponte apresentam os menores valores. Concluíram também que em função dos resultados obtidos no trabalho e pela análise econômica do corte da cana com ponta e despontada, a moagem da cana com ponta poderá influir na qualidade do açúcar produzido, mostrando-se viável para a produção de álcool e principalmente de energia, sem contudo inviabilizar a produção de açúcar. 
MELO et al (1988) conduziram um estudo com objetivo de avaliar o comportamento industrial da cana-de-açúcar sem queima prévia integral e despontada e queimada com e sem desponte em uma safra agrícola. Os parâmetros analisados que correspondem as condições de cana crua e queimada despontadas foram respectivamente: Brix: 18,00 e 15,90; Pol porcento do caldo: 15,90 e 13,01; Pol porcento da cana: 13,96 e 11,20; Fibra porcento da cana: 12,19 e 13,90 e Pureza: 88,34 e 81,99.

Pelos resultados médios apresentados os autores revelam que de uma maneira geral o melhor comportamento dos parâmetros tecnológicos, inclusive para açúcares totais são para cana crua despontada com elevação do teor de fibra porcento da cana. Outro aspecto de referência é o acréscimo de biomassa produzida pela matéria-prima proveniente do corte de cana crua, condição que se apresentou em torno de $20,60 \%$ maior do que a queimada despontada, enquanto que a queimada sem desponte teve um aumento de $15,00 \%$.

Estudando o aumento porcentual do teor de fibra em colheita mecanizada de cana-de-açúcar sem queima prévia, CERQUEIRA LUZ \& ALOISI (1991) obtiveram em média valores de $15,65 \%$.

Analisando os vários tipos de matéria-prima que são transferidas às usinas e destilarias, em função das técnicas de colheitas empregadas; cana-de-açúcar crua, queimada, cana queimada com ponta, cana parcialmente despontada e integral, DELGADO \& MAFRA (1989) salientam que este último tipo trata-se de uma matéria-prima de dificil manuseio pela grande quantidade de folhas presentes, e em virtude da não ocorrência da queima, sua constituição basicamente são colmo, folhas laterais, palmito e ponteiro apical, formado por folhas e inflorescências. É chamada de cana "energia", em razão da presença do elevado teor de fibra e folhas.

ABRAMO FILHO et al (1993), estudando os resíduos da colheita mecanizada de cana crua, para variedade SP 716163 determinaram que o resíduo pós-colheita formado pelo ponteiro e palhas que ficou no solo foi de $15 \mathrm{t} / \mathrm{ha}$, e que os possíveis efeitos da palha, deixada como cobertura promovem: a) menor temperatura do solo sob a palha, em 
comparação com solo desnudo; b) maior manutenção da umidade do solo; c) retardamento da brotação da soqueira que, todavia, pode ser uma questão varietal; d) controle de uma grande parte de plantas invasoras; e) possivel aumento de pragas; f) maior teor de matéria orgânica.

\subsection{Corte Manual da Cana-de-Açúcar}

FURLANI NETO (1991) descreve que os rendimentos obtidos para o corte de cana crua para mudas, na região Centro-Sul, sem amarração dos feixes, isto é, dispondo-se as canas em montes para o carregamento mecânico, tem variado de 2,5 a 3,0 $\mathrm{t}$ cana/homem dia. Para canaviais queimados o rendimento de corte tem variado de 5,0 a 7,0 $\mathrm{t}$ cana/homem dia. e adotando-se o sistema de corte da cana integral queimada (sem o desponte), os rendimentos aumentam para 7,0 a 8,0 t cana/homem dia. $O$ autor comenta ainda que para o corte manual de cana crua, é necessário evitar o desponte no local de formação dos montes, bem como promover a despalha, a fim de reduzir a quantidade de impurezas vegetais no carregamento.

Estudando a introdução de uma nova prática de corte a partir da formação de eitos de 5 e 7 linhas em uma safra agrícola, PEREIRA (1983), obteve um rendimento médio no corte de canas para mudas correspondente a 4,30 thomem dia e 4,20 thomem dia respectivamente. $O$ autor relata que a introdução do corte de 7 linhas amontoadas para cana queimada obteve em média 5,49 thomem dia, reduzindo também a quantidade de impurezas vegetais e minerais em $65,8 \%$ e $76,4 \%$ respectivamente.

PEIXOTO \& DELGADO (1988) estudando as operações agrícolas na cultura da cana-de-açúcar, com referência ao rendimento das frentes de corte, citam que o mesmo depende grandemente da disposição fisica dos cortadores, da variedade de cana escolhida, do tamanho e do porte dos colmos, de seu posicionamento nas touceiras, além da densidade do canavial, condições de topografia, tipo de solo e do tempo. Os autores comentam ainda 
que os rendimentos médios obtidos para o corte em canaviais sem queimar variam de 2 thomem dia para operários fracos de baixo nível de experiência e 4 t/homem dia para operários mais fortes e hábeis, e de 3 a 6 t/homem dia para o corte em cana queimada em canaviais com baixo rendimento agrícola e em condições pouco favoráveis. Para canaviais de médio e alto rendimento, obtem-se de 3 a 4,5 t/homem dia em cana sem queimar e de 4 a $7 \mathrm{t} / \mathrm{homem}$ dia em cana queimada, ocorrendo casos excepcionais que chegam a 10 thomem dia.

Em outro trabalho, PEIXOTO \& DELGADO (1988a) estudando o manejo da colheita na formação de eitos de 5 e 7 linhas, os autores determinaram para duas safras agrícolas os rendimentos médios para o corte manual e o desempenho operacional do carregamento mecânico da matéria-prima de 8,7 e 8,5 thomem dia e 43,5 e 54,8 t/h respectivamente.

Em artigo sobre a forma de quantificação do trabalho no corte manual da cana-de-açúcar para efeito de remuneração, BALBO (1987) indica um rendimento médio no corte de 6 thomem dia para cana queimada, evidenciando a relação entre os rendimentos de corte e da lavoura, esclarescendo que a remuneração do cortador não deve ser em função apenas do comprimento do eito de canas, mas levando-se em consideração também a produtividade agrícola.

Com objetivo de avaliar o efeito das impurezas minerais sobre o comportamento das características tecnológicas da cana-de-açúcar pelo Sistema de Pagamento pela Qualidade, MUTTON et al (1992) estudaram as seguintes características: brix e pol porcento do caldo, peso bagaço prensa, fibra e pol porcento da cana, valorização da matéria-prima (ágio/deságio) e pol porcento da cana padrão. Os autores concluem que para valores elevados de impurezas minerais (a partir de 4\%), ocorre a depreciação da qualidade da matéria-prima a ser processada, assim como sua valorização final, alterando os parâmetros tecnológicos principalmente fibra e pol porcento da cana e a valorização (ágio/deságio). 
Em estudo, comparativo entre a produtividade e a qualidade tecnológica da cana-de-açúcar para colheita mecanizada e corte manual em talhões comerciais de quatro usinas, FERNANDES \& IRVINE (1986) constataram que em cinco dos sete ensaios realizados, para as condições de canavial bem queimados e canas eretas, não ocorreram diferenças significativas entre os sistemas para a produtividade (t/ha), ocorrendo menor produção de açúcar $(17,0 \%)$, para os ensaios em que adotou-se o sistema de colheita semi-mecanizada em relação ao potencial de produtividade analisado por amostragem antes da queima.

Os autores afirmam que as perdas foram devidas às deficiências da colheita, perdas no carregamento e transporte, deterioração pós-colheita e inclusão de impurezas nas cargas, gerando $14,3 \%$ para o sistema de corte manual e $18,3 \%$ para o mecanizado. O corte mecanizado mostrou-se ineficiente contribuindo com um acréscimo na quantidade de matéria-prima, pela presença do cartucho de folhas e as folhas úmidas, que aumentaram o peso do material colhido e reduziram sua qualidade, teor de sacarose e pureza elevando os valores de fibra em $3,8 \%$, reduzindo em $5,0 \%$ o rendimento de açúcar por tonelada o que proporcionou uma redução significativa de $360 \mathrm{Kg}$ de açúcar por hectare.

\subsection{Carregamento e Qualidade da Matéria-Prima}

Com a introdução das carregadoras mecanizadas em substituição ao carregamento manual, resolveu-se parcialmente o problema de mão-de-obra, contribuindo para a redução dos custos operacionais.

Estudando novas técnicas da operação de carregamento de cana-de-açúcar, RIPOLI et al (1984) utilizaram uma carregadora com rastelo convencional e outra possuindo um conjunto denominado rastelo recolhedor, sobre eitos esteirados formados a partir de 5 e 7 linhas de plantio, em canaviais préviamente queimados.

Os autores obtiveram para carregamentos nos eitos formados por 7 linhas os 
seguintes valores relativos a capacidade operacional de 54,08 e 72,97 tha; tempos de carregamento de 9,53 e 10,77 min.; ciclos de carregamento de 20 e 24; percurso de 181,60 e 303,40 m e cargas líquidas de 9,640 e 12,100 t para máquinas com rastelo recolhedor e rastelo convencional respectivamente.

RIPOLI (1986) estudando o desenvolvimento de um modelo de desempenho operacional de carregadora auto propelida para cana-de-açúcar, obteve para desempenho operacional do carregamento a partir de eitos formados por 5 e 7 linhas 100,00 e $98,14 \mathrm{t} / \mathrm{h}$ respectivamente, o que levou o autor a concluir que o eito formado por 5 linhas esteirado foi o que apresentou melhores resultados na pesquisa.

RIPOLI et al (1975) estudando comparativamente três modelos de carregadoras com o corte manual, obtiveram para carregadoras convencionais uma capacidade efetiva de $41,71 \mathrm{t} / \mathrm{h}$, em matéria-prima proveniente de canaviais préviamente queimados. Os autores concluem que para os quatro sistemas de colheita estudados, o que apresenta menores custos foi corte mecânico seguido do crote manual, entretanto, apresentam os seguintes fatores a serem considerados na seleção de máquinas colhedoras: - disponibilidade de mão-de-obra; - qualidade da matéria-prima; - limitações no uso de máquinas e - rapidez no processamento da matéria-prima.

FERNANDES \& OLIVEIRA (1977), estudaram em duas safras do Estado de São Paulo os processos de colheita manual, semi-mecanizada e mecanizada, para cana-de-açúcar préviamente queimadas, onde procuraram estabelecer parâmetros para a avaliação da qualidade tecnológica da matéria-prima, através da participação porcentual de impurezas minerais e vegetais obervadas nas unidades transportadoras.

Os autores estimaram que a porcentagem de impurezas totais atribuídas ao carregamento podem estar contidas entre 1 a $20 \%$. Os dados médios de impurezas obtidos foram de 3,5\% (vegetais) e 2,5\% (minerais), e que após um período chuvoso ocorre elevação da porcentagem de impurezas em carregamentos de cana-de-açúcar, para qualquer que seja o processo de colheita. Os altos niveis de impurezas podem ser atribuídos não 
somente ao carregamento mecânico, como também, e principalmente, à altura do desponte (impurezas vegetais) e presença de terra (impurezas minerais). $\mathrm{O}$ processo de colheita semi-mecanizada conduz os maiores quantidades de impurezas minerais á usina.

BETANCOURT (1967) em Cuba, trabalhando em 152 usinas, estudou a presença de matéria estranha nos sistemas de colheita de cana-de-açúcar. $O$ autor determinou para a colheita semi-mecanizada, que a matéria-prima que chega à usina é constituída em média pelos seguintes elementos porcentuais em peso: ponteiros $=30,00$, folhas e palhas $=$ 42,83 , rebrotos $=9,21$, colmos $\operatorname{secos}=10,57$ e terra $=7,30$, e que a constituição média de matéria estranha é de $6,64 \%$ ponteiros; $0,21 \%$ rebrotos; $0,19 \%$ canas secas; $3,94 \%$ palha e folhas verdes e $0,19 \%$ terra.

Para avaliar a incidências de impurezas vegetais e minerais incorporadas à matéria-prima durante o carregamento, PEIXOTO \& DELGADO (1988a) conduziram cinco ensaios experimentais em 1985 e 1986, com corte em eitos de 5 e 7 linhas de cana com lavras em esteira contínua e em feixes obtendo os seguintes resultados para as safras de 85 e 86 respectivamente: matéria estranha vegetal: 4,02 e 2,16 e matéria estranha mineral: 1,43 e $0,61 \%$. Os autores concluem também que os teores de impurezas minerais incorporados a matéria-prima dependem mais diretamente dos sistemas de eitos formados pelo corte, tipos de lavras e do carregamento. Para os teores de impurezas vegetais, estes dependem mais da qualidade tanto da lavoura como da mão-de-obra empregada no corte.

\subsection{Perdas Pós-Colheita}

Os niveis de perdas de cana-de-açúcar no campo, por ocasião da colheita, foi estudado por PEIXOTO \& DELGADO (1988b). Os autores conduziram cinco ensaios experimentais em 1985 e 1986 com eitos de corte formados por 5 e 7 linhas compostas em esteira contínua e em feixes, obtendo os seguintes resultados médios em tha tocos 0,73 ; frações de colmos 0,46 e colmos inteiros não carregados 1,28 durante o ano agrícola de 
1985 e tocos 0,80; fraç̃̃es de colmos 0,41 e colmos inteiros não carregados 0,76 durante $o$ ano de 1986.

Os autores concluíram que as perdas totais $(0,75$ a $5,71 \mathrm{t} / \mathrm{ha})$, foram consideradas altas, e aumentaram devido aos níveis de rendimento agrícola, justificando um melhor treinamento da mão-de-obra de corte, a fim de proporcionar melhor qualidade de serviço.

Em trabalho comparativo entre o sistema de colheita com corte manual e o mecânico em cana-de-açúcar, FURLANI NETO (1984) observou perdas de cana nos tocos deixados pela altura do corte basal de 1,48 tha, além de 2,24 tha de colmos deixados durante o carregamento. Este autor obteve para impurezas minerais e vegetais índices na ordem de 2,39\% e 1,36\% respectivamente, justificaveis em função do uso do rastelo durante o carregamento mecânico, e que a qualidade da matéria-prima estaria também relacionada com a queima realizada para o corte e a altura do desponte.

ROSA et al (1993) estudando as perdas na colheita de cana-de-açúcar, verificaram para perdas totais obtidas pelas variedades testadas, valores médios de duas safras 89/90 e $90 / 91$ de 1,79 a 3,78 tha e 1,56 a 2,19 tha respectivamente. Os valores correspondentes a $\% /$ ha de perdas para as variedades SP 711406 foram 0,70 a $0,90 \%$ /ha para colmos menores que 1,20 metros; 0,52 a $0,56 \%$ /ha para ponteiros; 0,13 a $0,16 \%$ /ha para tocos e 0,11 a 0,12 $\% /$ ha para catação (colmos inteiros).

Com objetivo de comparar as perdas deixadas no campo pelo corte manual com canas amontoadas e o corte mecanizado de canas inteiras, FURLANI NETO et al (1984) obtiveram os seguintes resultados para o corte manual: 1,74 tha com perdas de canas inteiras (colmos encontrados no solo); 1,02 t/ha de frações de colmos agregada ao palmito e 0,76 correspondente ao toco deixado no campo pela altura de corte.

SHAW \& BROTHERTON (1992) estudaram na Austrália, a adoção de técnicas e métodos de colheita mecanizada em cana-de-açúcar sem queima prévia, que reduzisse as perdas de cana e os índices de matéria estranha estabelecidos em 2,96 a 4,42 tha. Os autores concluiram que não existe um ponto ótimo na relação entre perdas de cana e matéria 
estranha na colheita de cana crua, além de influenciar no sistema de transporte, produção, eficiência química e qualidade do açúcar, reduzindo as vantagens financeiras em se adotar a colheita de cana crua sobre a queimada.

FURLANI NETO et al (1989) estudaram comparativamente, as variedades NA 5679 e SP 711406 , colhidas mecanicamente em canaviais com e sem queima prévia. Em termos de perdas de colheita não encontraram diferenças significativas para as quantidades de Colmos, Pureza \% e Pol \% Cana analisadas entre ambas condições. Por sua vez a porcentagem de fibra na matéria-prima colhida sem queimar, foi 1,9\% maior significativamente do que a condição queimada, cujos valores médios na cana sem queimar foi de $14,94 \%$ e 15,38\% para as variedades NA 5679 e SP 711406 respectivamente. Para o resíduo pós-colheita deixado sobre o terreno (palhas, folhas verdes e ponteiros) a variação observada na condição de cana sem queimar foi de 7,50 a 11,88 tha.

\subsection{Potencial Energético da Cana-de-Açúcar}

RIPOLI et al (1991) estudando o potencial energético de resíduos provenientes da colheita em cana-de-açúcar sem queima prévia, nas variedades SP 70 1284; SP 70 1143; SP 70 6163; SP 711406 e NA 5679, determinaram os seguintes valores médios correspondentes ao potencial energético do palhiço (PEP) em Mcal/ha:

\begin{tabular}{cc}
\hline VARIEDADES & PEP (Mcal/ha) \\
\hline SP 701284 & $29.245,10$ \\
SP 706163 & $45.721,10$ \\
SP 701143 & $42.615,10$ \\
SP 711406 & $58.711,70$ \\
NA 5679 & $52.623,60$ \\
\hline
\end{tabular}


Os autores relatam, pelos resultados obtidos a importância da biomassa vegetal canavieira que atualmente é queimada no campo, representando grandes desperdícios de energia além de causar poluição ambiental.

Sobre a relação entre os poderes caloríficos, BRITO \& BARRICHELO (1982) comentam que poder calorífico de massas vegetais pode ser considerado tanto o superior - PCS como o inferior - PCI, somente dependerá se o calor liberado pela condensação da água de constituição do combustível é ou não considerado.

Os autores esclarecem que na prática, o poder calorífico inferior deve ser preferido, porém o processo de determinação ocorre com uso de bomba calorimétrica a qual fornece o poder calorífico superior. Para obter-se a relação entre PCS e PCI é necessário conhecer-se a quantidade de hidrogênio contida no material, tendo-se então descontado o valor consumido de vaporização da água envolvido no processo conforme a equação apresentada por DOAT (1977):

$\mathrm{PCI}=\mathrm{PCS}-600 \times 9 \mathrm{H} / 100$

onde:

$\mathrm{PCI}(\mathrm{kcal} / \mathrm{kg})$ - poder calorifico inferior

PCS $(\mathrm{kcal} / \mathrm{kg})$ - poder calorífico superior

$\mathrm{H}(\%)$ - teor de hidrogênio do material

600 - constante correspondente ao valor médio ( $\mathrm{kcal}$ ) de energia absorvida por $\mathrm{kg}$ de água para se atingir a temperatura de evaporação

9 - constante, múltiplo do peso de hidrogênio contido no combustível que fornece o peso da água formada durante a combustão.

ZULAUF et al (1985) realizaram análises preliminares sobre o potencial energético da palha obtida em canaviais das principais regiões do estado de São Paulo, numa etapa de pré-colheita. Estimaram os valores médios obtidos referentes aos poderes caloríficos superior e inferior da palha da cana-de-açúcar, sem considerar as folhas verdes e ponteiros. 


\begin{tabular}{lcccc}
\hline \multirow{2}{*}{ REGIÃO } & VARIEDADES & UMIDADE & PCS & PCI \\
\cline { 3 - 5 } & & $(\%)$ & $(\mathrm{kcal} / \mathrm{kg})$ \\
\hline BAURU & SP 701143 & 21,3 & 4315 & 3073 \\
\hline PIRACICABA & NA 5679 & 18,6 & 3979 & 2992 \\
\hline ARARAQUARA & NA 5679 & 9,1 & 4181 & 3563 \\
\hline RIB. PRETO & SP 70 1143 & 8,0 & 4096 & 3534 \\
\hline CAMPINAS & CP 5122 & 11,3 & 4098 & 3389 \\
\hline
\end{tabular}

A Bagatex ${ }^{1}$, estudando resíduos agrícolas e industriais provenientes da cana-de-açúcar, comparou quantidade e poder calorífico de algumas variedades, obtendo os seguintes resultados:

\begin{tabular}{lcccccc}
\hline & & BAGAÇ & PALHA & PONTEIRO & PONTEIRO+PALHA \\
\cline { 3 - 7 } VARIEDADES & CORTE & & & (t/ha) & \\
\hline NA 5679 & $4^{\circ}$ & 17 & - & - & 24 \\
\hline NA 5679 & $3^{\circ}$ & 14 & - & - & 29 \\
\hline SP 70 1143 & $1^{\circ}$ & 37 & 20 & 27 & 47 \\
\hline SP 70 1143 & $1^{\circ}$ & 32 & - & - & 50 \\
\hline SP 70 1248 & $1^{\circ}$ & 38 & 12 & 16 & 28 \\
\hline CB 5398 & $1^{\circ}$ & 39 & - & - & 39 \\
\hline PCI (kcal/kg) & & 1790 & 3600 & 1268 & 2280 \\
\hline
\end{tabular}

A quantidade de bagaço foi calculada a partir de $15,5 \%$ de fibra com $50 \%$ de umidade e o $\mathrm{PCl}$ calculado após 15 dias de secagem ao ar livre.

RIPOLI (1991), estudando a utilização do material remanescente da colheita de

1. BAGATEX. Analysis and prospects of rational utilization of sugar cane bagasse. Bagatex Program. Relatório Interno. Ribeirão Preto. 1984. 8p. 
cana-de-açúcar para as variedades NA 5679 e SP 711406, colhidas mecanicamente em canaviais sem queima prévia, obteve os seguintes valores correspondentes em tha para massa de colmos $=73,54$ e 67,20; de ponteiros $=9,91$ e 4,84; folhas verdes $=8,23$ e 5,26; palha $=11,52$ e 9,43; palhiço $=29,67$ e 19,53 e índice de palhiço $=0,40$ e 0,29 respectivamente para NA 5679 e SP 71 1406. O autor determinou para porcentagem de hidrogênio elementar o valor médio de $6,34 \%$ e os poderes calorificos superior, inferior e útil das frações de ponteiros, folhas verdes e palhas, obtendo os seguintes valores médios:

\begin{tabular}{lcccc}
\hline & & \multicolumn{3}{c}{ MÉDIAS } \\
\cline { 2 - 5 } VARIEDADES & VARIÁVEIS & PO & FV & PA \\
\hline \multirow{4}{*}{ SP 71 1143 } & PCS & 4334,10 & 4406,00 & 4508,80 \\
\cline { 2 - 5 } & PCI & 3998,30 & 4057,90 & 4179,30 \\
\cline { 2 - 5 } & PCU & 759,40 & 1177,90 & 3602,30 \\
\hline \multirow{3}{*}{ NA 5679 } & PCS & 4367,70 & 4418,20 & 4330,80 \\
\cline { 2 - 5 } & PCI & 4026,50 & 4268,60 & 3980,60 \\
\cline { 2 - 5 } & PCU & 1003,30 & 1457,80 & 3613,10 \\
\hline
\end{tabular}

$\mathrm{O}$ autor conclui que uma tonelada de material remanescente de colheitasubstitui 1,08 t de bagaço em termos de poder calorífico, se considerado como combustível para fornalhas de caldeiras em usinas e destilarias.

RIPOLI et al (1991), estudaram o enfardamento de resíduos provenientes da colheita manual de cana-de-açúcar variedade SP 706163 sem queima prévia, obtiveram os seguintes resultados médios em tha: massa de colmos $=79,52$; ponteiros $=7,04$; folhas verdes $=7,54 ;$ palha $=12,18$ e palhiço $=26,77$. Para o indice de palhiçoobtiveram $0,34 \%$ e seus respectivos poder calorifico superior, $\mathrm{PCS}=4.538,8 \mathrm{Kcal} / \mathrm{Kg}$; inferior $\mathrm{PCI}=4.200,2$ $\mathrm{Kcal} / \mathrm{Kg}$ e útil $\mathrm{PCU}=2.341,4 \mathrm{Kcal} / \mathrm{Kg}$. Os autores determinaram que a energia potencial bruta foi estimada em álcool $=23.921 \mathrm{Mcal} / \mathrm{ha}$; bagaço $=35.591 \mathrm{Mcal} / \mathrm{ha}$ e resíduos $=$ $62.679 \mathrm{Mcal} / \mathrm{ha}$. 
DOAT (1977) propõe a equação que fornece o valor aproximado do poder calorífico útil - PCU para madeira, com base em peso úmido:

$\mathrm{PCU}=\mathrm{PCI}[(100-\mathrm{E}) / 100]-6 \mathrm{H} / 100$

onde:

$\mathrm{PCU}(\mathrm{kcal} / \mathrm{kg})$ - poder calorífico útil à umidade $\mathrm{E}$

E (\%) - grau de umidade da madeira com base em peso úmido

6 - fator de conversão referente a energia para evaporação da água de formação.

RIPOLI et al (1990) estudando o potencial energético disponível em um hectare de cana-de-açúcar, sem queima prévia, basearam-se segundo resultados obtidos por outros pesquisadores, para uma produtividade agrícola de 70 tha e rendimento industrial de $75 \mathrm{l} / \mathrm{t}$ de etanol. Do processo industrial resultam 5.250 1/ha de etanol que oferecem um potencial energético de $20.877 \mathrm{Mcal} / \mathrm{ha} ; 17,5$ tha de bagaço obtidas que representam $31.325 \mathrm{Mcal} / \mathrm{ha}$ e 9,7 tha de material remanescente, formado por folhas e ponteiros que correspondem a $22.166 \mathrm{Mcal} / \mathrm{ha}$, totalizando um balanço energético disponivel de $74.368 \mathrm{Mcal} / \mathrm{ha}$.

Esses autores comentam ainda que para o aproveitamento da palhada como fonte energética existem algumas dificuldades a serem enfrentadas, como: material com baixa densidade $(25 \mathrm{Kg} / \mathrm{m} 3)$; teor de terra $(7,0 \%)$ e seu teor de umidade (ponteiros $=76,9 \%$, folhas verdes $=65,7 \%$ e palhas $=7,6 \%$ ), entretanto, esclarecem que soluções técnicas advirão, pois a adoção desse sistema de colheita de cana sem queima prévia beneficiará economicamente a agroindústria, reduzindo impactos ambientais e possibilitando a utilização de mais uma fonte energética.

Os autores citam as vantagens imediatas advindas da colheita de cana crua: 1) redução da poluição ambiental; 2) menores riscos de incêndios; 3) melhorias agronômicas e 4) potencial energético da palhada.

RIPOLI et al (1990a) estudando o comportamento das variedades SP 701284, SP706163 e SP 701143, com relação a porcentagem de umidade (U\%), índice de palhiço (IP), teor de hidrogênio ( $\mathrm{H} \%$ ), poder calorífico superior $(\mathrm{PCS})$, inferior $(\mathrm{PCI})$ e útil $(\mathrm{PCU})$ 
em $\mathrm{kcal} / \mathrm{kg}$ nas porções de ponteiros (1), folhas verdes (2) e palhas (3) colhidas manualmente e sem queima prévia, obtiveram os seguintes resultados médios para as variedades estudadas:

\begin{tabular}{lcc}
\hline & \multicolumn{2}{c}{ MÉDIAS } \\
\hline \multirow{U}{*}{ VARIÁVEIS } & $(1)$ & 76,88 \\
& $(2)$ & 65,73 \\
& $(3)$ & 7,63 \\
\hline \multirow{3}{*}{ PCS (kcal/kg) } & $(1)$ & 4297,20 \\
& $(2)$ & 4392,80 \\
& $(3)$ & 4285,20 \\
\hline & $(1)$ & 3960,70 \\
PCI (kcal/kg) & $(2)$ & 3948,90 \\
& $(3)$ & 3948,90 \\
\hline & $(1)$ & 880,40 \\
PCU (kcal/kg) & $(2)$ & 1351,70 \\
& $(3)$ & 3609,80 \\
\hline
\end{tabular}

Os autores concluíram que para PCS não ocorreram diferenças significativas, podendo ser considerado em média $4.300 \mathrm{kcal} / \mathrm{kg}$, e para a percentagem de hidrogênio elementar $(\mathrm{H})$ no material pode ser considerada em média $6,23 \%$.

MOLINA JUNIOR (1991) estudando o enfardamento de resíduos de colheita de cana-de-açúcar, obteve para o palhiço existente no campo os seguintes valores médios para poder calorífico supeior $=4.321,15$; inferior $=3.982,57$ e útil $=2.991,38 \mathrm{Kcal} / \mathrm{Kg}$, a umidade média foi de $24,1 \%$ e o potencial energético disponivel no resíduo de $37.397,83$ $\mathrm{Mcal} / \mathrm{ha}$. 


\subsection{Custos Operacionais}

FERRARI et al (1986) fizeram uma análise econômica preliminar da utilização ou não do desponte da cana-de-açúcar interpretada em função do Sistema de Pagamento pela Qualidade. Os autores observaram que os custos de produção por tonelada de cana, foram menores para canas sem desponte e os custos de produção por hectare foram iguais tanto para cana colhida com e sem desponte, em função principalmente da maior quantidade de cana a ser carregada e transportada por hectare.

Os preços por tonelada de cana foram menores para o processo sem desponte, enquanto que os valores por hectare são maiores, quando comparados as canas despontadas. Assim os autores concluem que a prática da colheita de cana com e sem desponte não apresentam incoveniente econômico com relação ao sistema de pagamento de cana pela qualidade.

OLIVEIRA \& BULLIO (1988), estudando os aspectos técnicos-econômicos do corte da cana-de-açúcar sem desponte e seus reflexos industriais na moagem, observaram que as principais implicações agronômicas da colheita de cana com ponta são devido a alterações, as quais dependem dos aspectos: - quantidade por hectare e qualidade da matéria-prima obtida do corte; - participação da cana com ponta e qualidade da ponta; preços e custos unitários agrícolas.

GEMENTE et al (1985) estudando a avaliação econômica comparativa da utilização agroindustrial dos resíduos provenientes da cana-de-açúcar colhida com ponta e despontada, baseados no desenvolvimento de equações ajustadas aos objetivos do trabalho, observaram a partir dos cálculos de rentabilidade econômica resultados que favorecem por pequena vantagem a prática do sistema de processamento que operaria com cana colhida despontada.

SILVA \& SILVA JUNIOR (1982) estudando o comportamento dos sistemas de colheita em cana crua e queimada, com e sem desponte, sob aspectos tecnológicos e 
econômicos, realizaram análises nas quais concluíram, que em relação ao custo de produção agrícola, incluíndo corte, carregamento e transporte, as canas colhidas sem desponte apresentaram menores custos por toneladas. 


\section{MATERIAL E MÉTODOS}

\subsection{Fundamentos da Hipótese de Trabalho}

Esse estudo visa caracterizar o desempenho operacional e econômico de sistema de colheita semi-mecanizada de cana-de-açúcar para as condições de canaviais com e sem queima prévia, levando-se em conta o aproveitamento de resíduos para fins energéticos.

A hipótese básica é que apesar do aumento dos custos operacionais na colheita sem queima prévia, pode haver vantagem econômica na adoção do sistema, caso se verifique a comercialização do bagaço liberado e o aproveitamento dos resíduos.

\subsection{Material}

O experimento foi conduzido em duas áreas pertencentes à Usina Costa Pinto, localizada no município de Piracicaba, São Paulo, nos meses de julho e agosto, durante a safra agrícola 91/92. As áreas, com tamanhos de 7,67 e 7,44 hectares foram denominadas de $\mathrm{A}$ e $\mathrm{B}$ respectivamente, e identificadas pela carta cartográfica correspondendo as seguintes características:

Área A - Longitude: $22^{\circ} 35^{\prime} 00^{\prime \prime}$

Latitude: $47^{\circ} 41^{\prime} 15^{\prime \prime}$

Altitude: $500 \mathrm{~m}$

Declividade: moderada de 6 a $10 \%$

Área B - Longitude: $22^{\circ} 37^{\prime} 30^{\prime \prime}$

Latitude: $47^{\circ} 37^{\prime} 30^{\prime \prime}$

Altitude: $632 \mathrm{~m}$

Declividade: suave de 0 a $5 \%$

Durante o período de ensaios registraram-se temperaturas médias, máxima de $31,8^{\circ}$ 
C, e mínima de $17,0^{\circ} \mathrm{C}$; a precipitação pluviométrica acumulada durante o período foi $11,10 \mathrm{~mm}$.

\subsubsection{Material de Campo}

a) A frente de corte

A frente de corte manual, designada para colheita da cana-de-açúcar, foi constituída por 30 pessoas entre homens e mulheres que faziam parte de uma equipe da própria usina. O grupo de trabalhadores braçais foi caracterizado e identificado pelo nome e idade.

b) Variedades de cana-de-açúcar

As variedades utilizadas no experimento foram SP 716163 e SP 71 1406, correspondendo respectivamente a $40 \%$ e $20 \%$ da área plantada na usina.

\begin{tabular}{cccc}
\hline ÁREAS & VARIEDADES & IDADE & CORTE \\
\hline A & SP 71 1406 & 10 meses & $2^{\circ}$ \\
\hline B & SP 71 6163 & 10 meses & $3^{\circ}$ \\
\hline
\end{tabular}

c) Tipos de solos

Os tipos de solo das áreas selecionadas correspondem: área A - Podzólico Vermelho Amarelo, equivalente eutrófico com textura argilosa e Terra Roxa Estruturada; área B - Latossolo Vermelho Escuro álico, distrófico com textura média, cuja caracterização granulométrica e grau de umidade encontram-se na Tabela abaixo. 


\begin{tabular}{|c|c|c|c|c|c|}
\hline \multirow{4}{*}{ ÁREAS } & \multicolumn{2}{|l|}{ CONDIÇÕES } & \multirow{3}{*}{\multicolumn{3}{|c|}{$(\%)$}} \\
\hline & DO & UMIDADE & & & \\
\hline & \multirow[t]{2}{*}{ CANAVIAL } & \multirow[t]{2}{*}{$(\%)$} & & & \\
\hline & & & AREIA & SILTE & ARGILA \\
\hline \multirow[t]{2}{*}{ A } & $\mathrm{CC}$ & 24,66 & 58,42 & 13,73 & 27,85 \\
\hline & $\mathrm{CQ}$ & 24,51 & & & \\
\hline \multirow[t]{2}{*}{ B } & $\mathrm{CC}$ & 12,55 & 64,93 & 8,67 & 26,40 \\
\hline & $\mathrm{CQ}$ & 10,89 & & & \\
\hline
\end{tabular}

d) Conjuntos mecanizados

Utilizou-se uma unidade carregadora de cana-de-açúcar marca MOTOCANA, montada em trator marca VALMET modelo 118.4, com tração dianteira auxiliar (TDA). As unidades de transporte foram compostas por caminhões marca MERCEDES-BENZ modelo 2219 , equipados com carroceria tipo fueiro, apropriada para transporte da cana-de-açúcar. Tanto a carregadora como os caminhões pertencem a frota própria da usina.

e) Equipamentos de mensuração dimensional

Para a medição das distâncias, comprimentos, diâmetros, caracterização do canavial e demarcação de áreas foram utilizados os seguintes utensílios:

- Trena de fibra marca ESLON, com $50 \mathrm{~m}$, divisão de $0,01 \mathrm{~m}$;

- Paquímetro marca MYTUTOYO, capacidade de leitura 0,1 mm;

- Gabarito triangular de ferro de $3 / 8$ polegadas de diâmetro, de construção artesanal, com catetos de $1 \mathrm{~m}$ de comprimento e capacidade de leitura de $45^{\circ}$ e $22,5^{\circ}$.

f) Equipamentos de mensuração ponderal e temporal

Os equipamentos utilizados para determinação das massas de plantas e suas frações colhidas manualmente, e os tempos de trabalho das carregadoras foram: 
- Balança de prato marca DAYTON, capacidade máxima de carga $10 \mathrm{~kg}$ e capacidade de leitura de $10^{-2} \mathrm{~kg}$;

- Balança de prato sem marca, capacidade de $10 \mathrm{~kg}$ e capacidade de leitura de $10^{-1} \mathrm{~kg}$.

- Cronômetro digital marca CASIO, com precisão de centésimos de segundos.

g) Equipamentos de aplicação geral

Foram utilizados materiais de aplicação geral para demarcações, identificação e acondicionamento de amostras, tais como: estacas de madeira; sacos plásticos; rolos de fita adesiva; lona plástica e barbante.

\subsubsection{Material de Laboratório}

a) Máquinas e equipamentos para determinação da análise tecnológica e de impurezas da matéria-prima

Para a análise tecnológica das amostras de matéria-prima e do resíduo pós-colheita, utilizou-se:

- Amostrador tratorizado tipo sonda marca SANTAL, acoplado ao trator marca VALMET modelo 65;

- Desintegrador de fibras marca PENHA, rotação máxima de 1700 rpm;

- Betoneira homogeinizadora marca IRBI/A modelo 150, rotação de 23 rpm;

- Balança de plataforma, sem marca, com capacidade de carga de $50 \mathrm{~kg}$ e capacidade de leitura de $1 \mathrm{~kg}$;

- Balança analítica marca METTLER modelo PH-45 com capacidade de carga de $4,0 \mathrm{~kg}$ e capacidade de leitura de $10^{-5} \mathrm{~kg}$;

- Prensa hidráulica marca CODISTIL com capacidade para $250 \mathrm{Kg}$;

- Sacarímetro automático digital marca ACATEC modelo Autopol; 
- Refratômetro marca AO - OPTICAL;

- Mufla marca QUIMS, temperatura máxima de $1200^{\circ} \mathrm{C}$;

- Peneiras de tela de metal;

- Cápsulas de porcelana.

Todos os equipamentos descritos são de propriedade da Usina.

b) Equipamentos para determinação do poder calorífico e teor de água nas frações componentes da matéria-prima

Os equipamentos utilizados para determinação do poder calorífico e o teor de água nas frações componentes dos resíduos pós-colheita foram:

- Estufa marca FANEM modelo $315 \mathrm{SE}$, temperatura variável de $37^{\circ}$ a $220^{\circ} \mathrm{C}$;

- Balança analítica marca METTLER modelo H10, com capacidade de carga 160g, capacidade de leitura de $10^{-3} \mathrm{~g}$;

- Bomba calorimétrica marca INCOMAP modelo D-217;

- Mufla marca FORMITEC, temperatura máxima de $1200^{\circ} \mathrm{C}$;

- Cápsulas de porcelana;

\subsection{Métodos}

\subsubsection{Determinações de Campo}

Para as determinações de campo, as áreas previamente selecionadas foram divididas em duas partes iguais, limitadas por um carreador, nas quais se realizaram os experimentos. Inicialmente foi executado o tratamento caracterizado para a condição de cana crua e posteriormente para a condição de cana queimada. 
a) Porte do canavial

O porte do canavial foi determinado segundo o método proposto por RIPOLI \& MIALHE (1987), que estabelece o percentual de colmos eretos, acamados ou deitados no canavial.

b) Caracterização dimensional e ponderal das plantas e suas frações

Para a caracterização do canavial adotou-se os métodos propostos por RIPOLI (1991). Tomou-se ao acaso cinco parcelas para cada condição estabelecida do canavial (cana crua ou queimada), limitadas pelo espaçamento entre uma linha de plantio, 1,10 metros e o comprimento de 2,0 metros lineares ao longo dessa linha, correspondendo a uma área amostral de $2,20 \mathrm{~m}^{2}$.

Para cada parcela, colheu-se manualmente todas as plantas sendo posteriormente separadas em frações determinando-se suas massas correspondentes. As amostras foram retiradas do canavial, sendo depositadas sobre uma lona plástica no chão, onde procedeu-se a separação dos colmos e das partes constituintes do palhiço: palhas (folhas secas), folhas verdes e ponteiros. Para os colmos, determinou-se ainda seu comprimento, diâmetro (na altura do $4^{\circ}$ internódio proximal) e o número de internódios. Para a condição de cana crua, as palhas que se desprenderam ao longo do ciclo fenológico e cairam no solo, também foram recolhidas. As variáveis correspondentes às massas de colmos, ponteiros, folhas verdes e palhas foram submetidas a análise estatística pelo confronto de seus valores para os tratamentos propostos. De cada fração correspondente ao palhiço, retirou-se sub-amostras que foram acondicionadas e identificadas em sacos plásticos, e encaminhadas ao laboratório para a determinação do teor de água e poder calorífico.

c) Capacidade de campo operacional do corte manual

A capacidade operacional dos trabalhadores braçais, medida em toneladas cortadas por homem dia (t/hd) foi avaliada para ambos os tratamentos com cana crua e queimada, 
seguindo a metodologia empregada pela usina que considera a jornada diária de trabalho para fins de pagamento.

A operação de corte manual adotada consistiu em realizar o corte basal do colmo e o desponte apical dos ponteiros, considerando-se 6 linhas de plantio, espaçadas de 1,10 metros, para formação dos eitos, que foram dispostos em montes.

O acompanhamento do corte se deu de acordo com o avanço da frente, através de sucessivas medições, definidas em função dos períodos: inicial - a partir do início da jornada de trabalho até a parada para o intervalo de almoço; intermediário - após o intervalo de almoço até a parada para o lanche e final - após o término do lanche até o final do expediente. $\mathrm{O}$ intervalo de tempo efetivamente trabalhado, corresponde a aproximadamente 1 hora e 50 minutos para cada um dos três períodos considerados, totalizando 5 horas e 30 minutos.

As quantidades cortadas foram devidamente registradas em planilhas e submetidas a análise estatística, elegendo-se o teste de " $t$ " para a comparação entre seus valores, com intervalo de confiança estabelecido para o nivel de 5\% de significância.

d) Capacidade de campo operacional do carregamento e transporte

A avaliação da capacidade de campo operacional do carregamento mecanizado da matéria-prima nas áreas experimentais, determinadas em termos de toneladas de cana carregada por hora, foi realizada através de 10 amostragens efetuadas ao acaso durante a operação. Cada amostra corresponde ao carregamento de uma unidade de transporte (caminhão), sendo considerados os seguintes parâmetros:

- tempo de carregamento: tempo cronometrado a partir do início do carregamento até se completar a carga admissivel da unidade de transporte;

- ciclo operacional da carregadora: considerado a partir do início do rastelamento do eito, até o início do rastelamento subsequente, observada a capacidade máxima de carga admitida pela máquina; 
- distância percorrida durante o carregamento: correspondendo à distância medida entre a estaca cravada a partir do ponto inicial, até a estaca cravada no local onde se deu o completo carregamento da unidade de transporte; e

- largura do eito, correspondendo a dimensão delimitada pelas 6 linhas de plantas cortadas para a formação dos eitos.

O transporte da matéria-prima foi devidamente acompanhado. Os caminhões considerados como unidades amostrais, foram identificados e monitorados desde o carregamento nas áreas experimentais até o descarregamento na unidade industrial, onde eram pesados e retiradas as amostras para análise tecnológica e de impurezas. As distâncias entre os locais de carregamento e descarregamento eram préviamente conhecidas.

Devido ao sistema operacional adotado pela Usina, as velocidades dos caminhões foram determinadas através dos valores médios fornecidos pela Empresa para as condições locais.

Os valores correspondentes às cargas transportadas foram obtidos pelo controle de peso da cana $(\mathrm{CPC})$, através do registro individual efetuado na balança da indústria.

As variáveis obtidas na capacidade operacional do carregamento e transporte, foram submetidas a análise estatística pelo confronto de seus valores para os tratamentos propostos.

e) Determinação do teor de água e granulometria do solo

Para determinação do teor de água e granulometria dos solos das áreas experimentais, coletou-se, ao acaso, amostras considerando 5 repetições para cada tratamento, no perfil de 0 a $10 \mathrm{~cm}$ de profundidade. As amostras foram acondicionadas em vasilhas de alumínio que após serem vedadas e identificadas foram encaminhadas para determinações laboratoriais. 
f) Determinações pós-colheita

Após a retirada da matéria-prima das áreas experimentais, uma equipe de trabalhadores realizou a "catação", ou seja, o recolhimento dos colmos industrializáveis, deixados no campo pelo processo de carregamento. A seguir, escolheu-se, ao acaso, cinco parcelas para cada tratamento, caracterizadas como repetições, dentro de cada área experimental. Cada parcela era formada por 5 linhas consecutivas de plantio e 10 metros lineares de comprimento, correspondendo a uma área amostral de $55,0 \mathrm{~m}^{2}$. O material recolhido foi classificado e pesado, identificando-se: canas inteiras (colmos, matéria-prima cortada não carregada e não recolhida pela equipe de catação); frações de colmos (tocos deixados na soqueira, em razão da altura do corte basal e pontas, percentagem de matéria-prima existente junto ao ponteiro); folhas verdes/secas e ponteiros, que compões o palhiço. As variáveis caracterizadas por colmos, frações de colmos, ponteiros e folhas verdes e secas, foram submetidas a análise estatística, onde seus valores foram confrontados para os tratamentos propostos.

\subsubsection{Determinações Laboratoriais}

a) Caracterização tecnológica de impurezas minerais e vegetais da matéria-prima

A matéria-prima das unidades de transportes foi submetida à amostragem pelo sistema de sonda existente no laboratório da usina, que analisa a qualidade da matéria-prima para efetuar o pagamento da cana pela qualidade. O conteúdo das amostras foi depositado sobre lona plástica procedendo-se à separação das as frações: palhas, folhas verdes, ponteiros e colmos, cujas massas foram determinadas individualmente. A seguir, o material foi novamente homogeneizado, triturado e submetido à Sistemática de Pagamento pela Qualidade, conforme estabelecido pela metodologia proposta pelos padrões contida no Ato no 32/89 de 28 de agosto de 1989, do Instituto do Açúcar e Álcool (IAA/PLANALSUCAR). As variáveis obtidas na caracterização tecnológica da 
matéria-prima, e as correpondentes aos valores de impurezas minerais e vegetais foram submetidas a análise estatística pelo confronto entre os tratamentos considerados.

b) Determinação do teor de água e poder calorífico superior, inferior e útil das frações das plantas

As sub-amostras do material vegetal, provenientes das áreas experimentais, (conforme descrito no ítem 3.3.1. sub-ítem b), correspondentes as determinações de campo, foram divididas em dois grupos de forma que o primeiro foi submetido à determinação do teor de água e o segundo a determinação do poder calorífico. O teor de água foi obtido através da secagem do material em estufa a $70^{\circ} \mathrm{C}$ por 24 horas, até obter-se peso constante, quando então o material é considerado seco. $\mathrm{O}$ teor de água foi determinado com base em peso úmido, pela equação:

$$
U(\%)=[(\text { Peso úmido }- \text { Peso seco }) /(\text { Peso úmido })] \times 100
$$

Para determinação do poder calorifico superior do material, utilizou-se a norma NBR 8633 da ASSOCIAÇÃO BRASILEIRA DE NORMAS TÉCNICAS (ABNT, 1984) que estabelece critérios para a determinação do poder calorifico superior do carvão vegetal.

O poder calorífico superior é definido como o número de unidades de calor liberado pela combustão de uma unidade de massa de determinada substância, em bomba calorimétrica, em atmosfera de oxigênio, a volume constante e sob condições específicas, de modo que toda a água proveniente da combustão esteja no estado líquido. Tal utilização se fez necessária, em razão da ausência de Norma Técnica específica para determinação em resíduos oriundos de colheita de produtos agrícolas.

A partir dos valores obtidos para o poder calofifico superior; quantidade de calor absorvido para vaporização da água; proporção de água formada na combustão; quantidade de hidrogênio do combustível e o teor de água do material, utilizando-se as equações 
propostas por DOAT (1977), estimou-se o poder calorífico inferior e o poder calorífico útil, a saber:

$\mathrm{PCI}=\mathrm{PCS}-600 \times 9 \mathrm{H} / 100$

onde:

$\mathrm{PCI}(\mathrm{kcal} / \mathrm{kg})=$ poder calorifico inferior;

$\mathrm{PCS}(\mathrm{kcal} / \mathrm{kg})=$ poder calorifico superior;

$\mathrm{H}(\%)=$ teor de hidrogênio do material;

600 = valor médio da energia absorvida por kg de água para atingir a temperatura de vaporização;

$9=$ múltiplo do peso do hidrogênio no combustível, fornecendo o peso da água formada na combustão.

$P C U=P C I[(100-E) / 100]-6 \mathrm{H} / 100$

onde,

$\mathrm{PCU}(\mathrm{kcal} / \mathrm{kg})=$ poder calorifico útil;

$\mathrm{E}(\%)=$ teor de água do material com base no peso úmido;

6 = fator de conversão referente à energia para evaporação da água de formação;

$\mathrm{H}(\%)=$ teor de hidrogênio do material.

O teor de hidrogênio, utilizado como coeficiente nas equações, foi de $6,27 \%$, baseado no valor médio sugerido por RIPOLI et al (1990).

c) Determinação do grau de umidade e granulometria do solo

Para determinação do grau de umidade, adotou-se o método da estufa a $105^{\circ} \mathrm{C}$ por 24 horas, até a obtenção de peso constante. Para a análise granulométrica do solo amostrado adotou-se o método de Bouyucos, conforme descrito em KIEHL (1979). 


\subsubsection{Avaliação de Desempenho Econômico dos Sistemas}

Para avaliação econômica dos sistemas envolvidos, desenvolveu-se um modelo econômico representativo baseado na equação clássica de lucro, a qual é definida por:

$R L E=R B-C$

onde:

RLE - receita líquida estimada (US\$/t) *

$\mathrm{RB}$ - receita bruta

C - custos

Para a parcela correspondente a receit7a bruta, expressa em US\$/t, considerou-se:

$R B=R C A+R B A+R P A$

onde:

RCA - receita da cana/t

$\mathrm{RBA}$ - receita do bagaço/t

RPA - receita do palhiço/t

As variáveis que compõe a receita bruta dependem da oferta de demanda para cana-de-açúcar, bagaço e palhiço existentes no mercado.

O termo correspondente aos custos, determinados em US\$/t, envolvidos no processo de colheita foram definidos como:

* - O uso do dolar comercial americano como unidade monetária é devido as altas taxas inflacionárias do País. 
$\mathrm{C}=\mathrm{CCR}+\mathrm{CCA}+\mathrm{CT}+\mathrm{CI}+\mathrm{CRP}$

onde:

C - custos totais dos processo/t

CCR - custos de corte/t

$\mathrm{CCA}$ - custos de carregamento/t

CT - custos de transporte/t

$\mathrm{CI}$ - custos indiretos/t

CRP - custos de recolhimento do palhiço/t

Os custos indiretos (CI) são obtidos por:

$\mathrm{CI}=\mathrm{CL}+\mathrm{CPC}$

onde:

CLC - custos de lavagem da cana/t

$\mathrm{CPC}$ - custos de perdas da cana/t

Substituindo-se a equação (7) na equação (6), tem-se:

$\mathrm{C}=\mathrm{CCR}+\mathrm{CCA}+\mathrm{CT}+\mathrm{CRP}+\mathrm{CLC}+\mathrm{CPC}$

A equação (8) expressa o custo total para os processos de cana crua e queimada. Substituindo-se as equações (8) e (5) na equação (4), tem-se: 


$$
\mathrm{RLE}=(\mathrm{RCA}+\mathrm{RBA}+\mathrm{RPA})-(\mathrm{CCR}+\mathrm{CCA}+\mathrm{CT}+\mathrm{CRP}+\mathrm{CLC}+\mathrm{CPC})
$$

A equação (9) expressa o saldo econômico dos processos entre o corte, carregamento e transporte para as condições propostas de cana crua e queimada. A essa equação serão aplicados os dados originais obtidos pelo levantamento de campo nas operações, e dados baseados nas informações fornecidas pela Usina Costa Pinto. Os valores referentes aos custos de oportunidade correspondente a cana-de-açúcar e de bagaço foram fornecidos pela Cooperativa dos Fornecedores de Cana do Estado de São Paulo, constantes no Apêndice 1. Para os valores referentes a receita do palhiço, considerou-se o preço de oportunidade de substituição do palhiço pelo bagaço, atribuindo-se que 1 tonelada de palhiço corresponde a 1,66 toneladas de bagaço, (MOLINA JUNIOR, 1991) sendo o custo médio de recolhimento estimado em US\$ 3,55/t segundo estabelecido por RIPOLI (1991).

\subsubsection{Análise estatística}

O delineamento experimental, constou de 2 tratamentos caracterizados pelas condições em que se encontrava a matéria-prima para colher, ou seja: cana crua e cana queimada. De cada tratamento foram tomadas, 5 repetições (amostras), submetidas à análise estatística não-paramétrica por comparação de duas amostras independentes, utilizando-se o Teste de Wilcoxon ou Teste da Soma das Ordens "Rank Summ Test", conforme descrito por CAMPOS (1984). A adoção desse procedimento se deve ao pequeno número de amostras e a violação, embora não drástica, das pressuposições básicas para a aplicação dos métodos estatísticos do campo paramétrico. 


\section{RESULTADOS E DISCUSSÃO}

Os resultados apresentados são baseados nos dados originais obtidos ou transformados a partir dos valores contidos nos Apêndices 1 e 2 .

\subsection{Caracterização do Canavial}

\subsubsection{Porte e caracterização dimensional do canavial}

A Tabela 1 apresenta os resultados médios obtidos pela coleta manual das plantas e pela verificação das condições fisicas em que se encontrava o canavial das áreas experimentais.

TABELA 1 - Valores médios que expressam as características dimensionais e porte do canavial, para as áreas experimentais A e B.

\begin{tabular}{cccccc}
\hline & & & \multicolumn{3}{c}{ COLMOS } \\
\cline { 3 - 6 } ÁREAS CONDIÇÕES & PORTE & ESPAÇAMENTO & DIÂMETRO & ALTURA \\
& & ERETO & $(\mathrm{m})$ & $(\mathrm{m})$ & $(\mathrm{m})$ \\
& & $(\%)$ & & & \\
\hline \multirow{2}{*}{$\mathrm{A}$} & $\mathrm{CC}$ & 88,82 & 1,12 & 0,0269 & 2,61 \\
& $\mathrm{CQ}$ & 88,26 & 1,14 & 0,0248 & 2,45 \\
\hline \multirow{2}{*}{ B } & $\mathrm{CC}$ & 100,00 & 1,07 & 0,0247 & 1,72 \\
& $\mathrm{CQ}$ & 100,00 & 1,08 & 0,0234 & 1,73 \\
\hline CC - cana crua (canavial sem queima) CQ - cana queimada (canavial com queima)
\end{tabular}

A análise dos dados da Tabela 1 permite observar que as plantas apresentam um condicionamento que garante ao canavial um porte praticamente ereto, facilitando portanto 
a operação de corte manual. Verifica-se também, uma certa uniformidade para os valores de espaçamento entre linhas bem como, para as dimensões dos colmos.

\subsubsection{Caracterização ponderal do canavial}

\section{a) Material vegetal}

$\mathrm{Na}$ Tabela 2 encontram-se os resultados médios observados, em tha, para as variáveis que possibilitam a caracterização ponderal do canavial, obtidas com base nas amostras colhidas manualmente nas áreas experimentais estudadas A e B para os tratamentos propostos de canavial com (CQ) e sem (CC) queima prévia.

TABELA 2 - Quantidades médias estimadas de massas de colmos (MCO); ponteiros (MPO); folhas verdes (MFV) e palhas (MPA) para as áreas experimentais, nas condições de cana crua (CC) e cana queimada (CQ).

\begin{tabular}{rrrrr}
\hline ÁREAS & PARÂMETROS & $\begin{array}{r}\text { CC } \\
\text { (t/ha) }\end{array}$ & (n.m.s.) & $\begin{array}{r}\text { CQ } \\
\text { (tha) }\end{array}$ \\
\hline \multirow{2}{*}{ A } & MCO & 136,64 & $(3,10)$ & 107,73 \\
& MPO & 8,02 & $(\mathrm{NS})$ & 5,91 \\
& MFV & 16,87 & $(3,10)$ & 10,26 \\
& MPA & 8,36 & $(3,10)$ & 0,33 \\
\hline \multirow{2}{*}{ B } & MCO & 95,09 & $(N S)$ & 109,58 \\
& MPO & 5,07 & $(N S)$ & 6,86 \\
& MFV & 12,64 & $(N S)$ & 10,50 \\
& MPA & 8,64 & $(3,10)$ & 0,28 \\
\hline
\end{tabular}

$($ n.m.s. $)=$ nivel minimo de significância, Teste de Wilcoxon

NS = não significativo (n.m.s. $>10 \%$ ) 
Pela análise da Tabela 2, observa-se que as massas médias de colmos obtidas na área experimental A, apresentaram diferenças significativas entre os tratamentos propostos, com maiores valores correspondentes à condição de cana crua. Verifica-se que a maior produtividade da cana crua implica proporcionalmente em uma maior produção da massa de palhiço, representada pelas massas de ponteiros, folhas verdes e palhas, e cujo percentual referente aos componentes da massa vegetal e a massa de colmos produzidas em relação á massa total, mantiveram índices coerentes. Os índices obtidos foram respectivamente para cana crua e cana queimada: massa de colmos 80,42 e 86,72\%; massa de ponteiros 4,72 e $4,76 \%$; massa de folhas verdes 9,93 e $8,26 \%$; massa de palha 4,92 e $0,27 \%$. Os índices verificados para a massa de palha, indicam claramente a ação de limpeza do fogo para a colheita.

Para a área experimental B, não houve diferenças estatísticamente significativas, entre os valores correspondentes a massa de colmos. A massa de ponteiros e folhas verdes também não diferiram entre sí para as situações propostas de cana crua e queimada. Já para a massa de palha, a diferença é significativa, pelo motivo do uso de fogo para a limpeza.

Para ambas as áreas experimentais, os tratamentos tiveram comportamentos semelhantes na distribuição da massa vegetal sobre a quantidade total colhida.

A Figura 1 apresenta os valores médios para a área $\mathrm{A}$ nos tratamentos de cana crua e queimada. 
DISTRIBUICAO DA MASSA VEGETAL

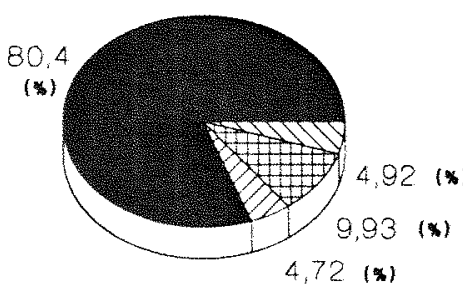

CANA CPUA

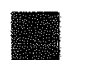

MCO = Masa de colmos

MPO * MBEB de pontoiros

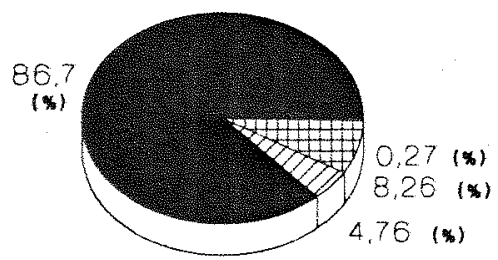

CANA QUEIMADA

MFV * Masaa de folnas vordes

MPA = Massa de palhas

FIGURA 1- Distribuição percentual da massa vegetal (média) sobre a quantidade total colhida para a Área A nas condições de cana crua e queimada

Nos resultados, observa-se conformidade quando comparados com outros autores. RIPOLI et al (1991) determinaram em amostras colhidas manualmente em canaviais sem queima prévia, os seguintes indices médios para massas de colmos, 74,82\%; ponteiros, $6,62 \%$; folhas verdes, $7,09 \%$ e palha, $11,46 \%$. Resultados semelhantes foram obtidos por RIPOLI (1991), com duas variedades distintas tendo verificado os seguintes valores para massas de colmos 71,26 e 77,48\%; ponteiros, 9,60 e 5,58\%; folhas verdes, 7,79 e 6,10\% e palhas, 11,16 e $10,87 \%$. A variação existente quando comparada aos valores obtidos no presente trabalho, deve-se as diferenças, principalmente no rendimento agrícola obtido.

\section{b) Indice de palhiço}

$O$ índice de palhiço (IP), calculado pela razão entre a massa média observada de palhiço, (somatória das porções de folhas verdes, ponteiros e palhas), e a quantidade obtida 
de colmos, caracteriza quantitativamente a relação entre o material remanescente disponível no campo e a fração industrializável da matéria-prima. Os dados são mostrados na Tabela 3.

TABELA 3 - Valores porcentuais obtidos para índice de palhiço (IP) nas áreas experimentais A e B, para as condições de cana crua (CC) e cana queimada $(\mathrm{CQ})$.

\begin{tabular}{cccc}
\hline ÁREAS & CC & (n.m.s.) & CQ \\
\hline A & 0,25 & $(3,10)$ & 0,15 \\
B & 0,28 & $(3,10)$ & 0,16 \\
\hline
\end{tabular}

Pode-se verificar que, para ambas as áreas experimentais, os maiores índices correspondem à condição de cana crua, o que era esperado diante do fato de colher-se a cana sem queima prévia. Esses resultados estão de acordo com os obtidos por RIPOLI et al (1991) e RIPOLI (1991) e MOLINA JUNIOR (1991) analisados para diferentes idades e variedades de cana-de-açúcar.

\subsection{Capacidade de Campo Operacional do Corte Manual ${ }^{1}$}

A Tabela 4 mostra os valores médios em toneladas/homem-dia, correspondentes à capacidade de corte manual de cana-de-açúcar, confrontando-os para as condições de cana crua e cana queimada, estando os valores originais no Apêndice 1.

1 - As definições de Capacidade de Campo Operacional apticadas a este texto, estão de acordo com o conceito proposto por MIALHE (1974). 
TABELA 4 - Capacidade de campo operacional do corte manual: Valores médios, em toneladas/homem.dia, para as condições de cana crua (CC) e cana queimada (CQ) nas áreas experimentais.

\begin{tabular}{|c|c|c|c|}
\hline \multirow[b]{2}{*}{ ÁREAS } & \multirow[b]{2}{*}{ VARIEDADES } & \multicolumn{2}{|c|}{$\begin{array}{l}\text { CAPACIDADE DE CAMPO } \\
\text { OPERACIONAL } \\
\text { (t/homem.dia) }\end{array}$} \\
\hline & & $\mathrm{CC}$ & $\mathrm{CQ}$ \\
\hline A & SP 711406 & $3,67 \mathrm{a}$ & $6,90 \mathrm{~b}$ \\
\hline $\mathrm{B}$ & SP 716163 & $2,94 \mathrm{a}$ & $10,59 \mathrm{~b}$ \\
\hline
\end{tabular}

Pela análise dos resultados observa-se que, para ambas as áreas experimentais, a capacidade de campo operacional do corte manual foi muito superior quando se considerou a condição de cana queimada em relação a cana crua, representando uma diferença de 1,88 vezes, ou seja, $88 \%$ a mais para a área experimental A e 3,60 vezes, ou $260 \%$ a mais para a área $B$. Este fato evidencia o porque da preferência atual do corte com cana queimada. 


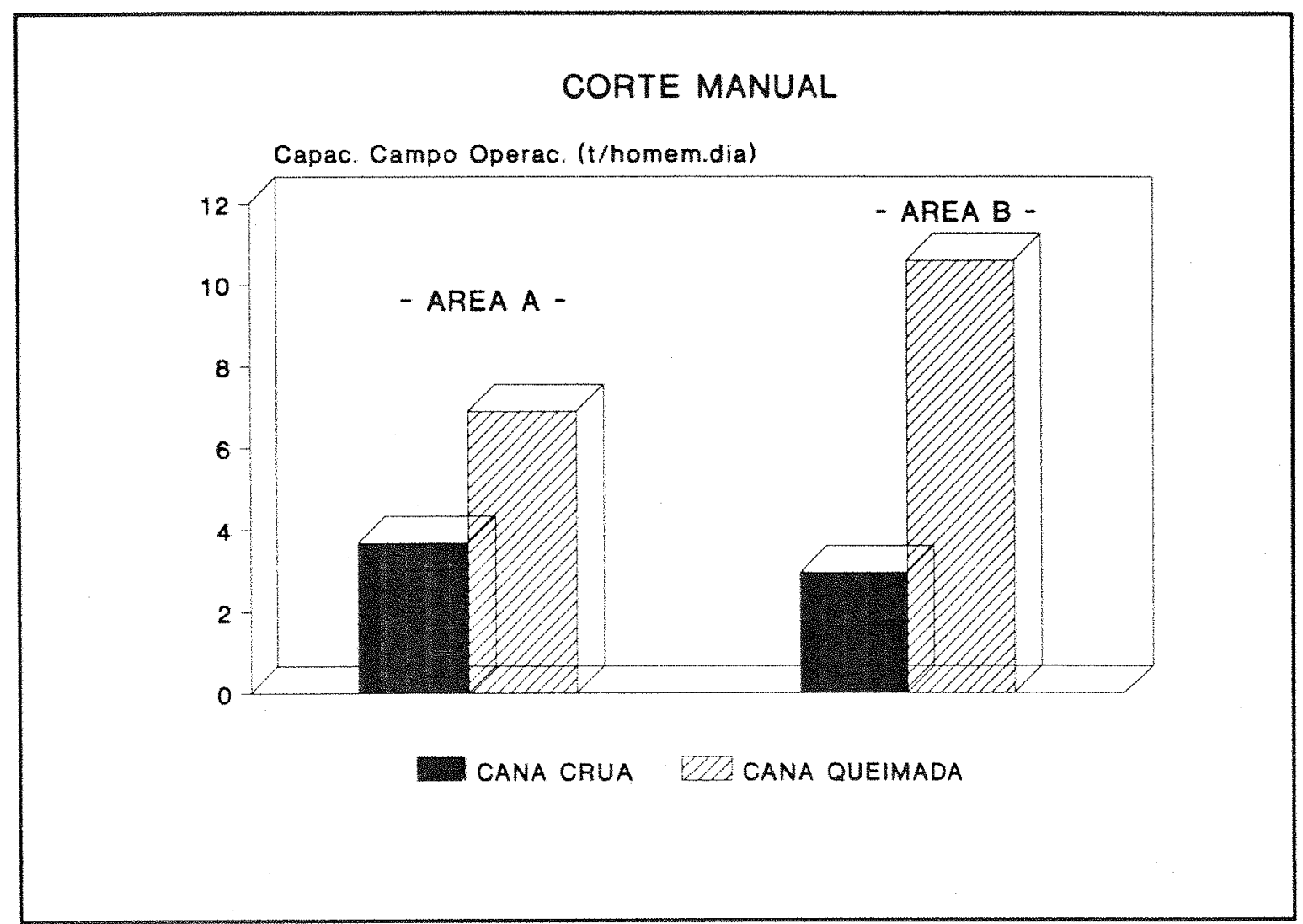

FIGURA 2 - Capacidade de campo operacional dos cortadores de cana-de-açúcar para as Áreas A e B nas condições de cana crua e queimada.

Pelos resultados, verifica-se que os índices obtidos para as capacidades operacionais de corte manual considerados para ambos os tratamentos em cana crua ou queimada, estão nos limites estabelecidos por outros autores, os quais são apresentados na Tabela 5: 
TABELA 5 - Valores médios referente a capacidade operacional do corte manual de cana-de-açúcar.

\begin{tabular}{ccc}
\hline & & DESEMPENHO \\
AUTORES & CONDIÇÃO DO & OPERACIONAL \\
& CANAVIAL & NO CORTE MANUAL \\
& & $(\mathrm{t} / \mathrm{h} . \mathrm{d})$ \\
\hline FURLANI NETO (1991) & CC & 2,5 A 3,0 \\
\hline PEIXOTO \& DELGADO (1988) & CC & 5,0 A 7,0 \\
\hline PEIXOTO \& DELGADO (1988a) & CQ & 3,0 A 4,5 \\
\hline BALBO (1987) & CQ & 4,0 A 7,0 \\
\hline PEREIRA (1983) & CC & 8,5 \\
\hline
\end{tabular}

\subsection{Capacidade de Campo Operacional do Carregamento e Transporte}

\subsubsection{Carregamento}

A operação de carregamento, realizada nos tratamentos de cana crua e cana queimada, foi avaliada pelo valor médio das variáveis apresentadas na Tabela 6, que definem a eficiência desse processo na transferência da matéria-prima do campo à unidade de transporte. 
TABELA 6 - Avaliação do tempo; número de ciclos; percurso e da capacidade operacional do carregamento da matéria-prima recolhida nas áreas experimentais, para as condições de cana crua e cana queimada.

\begin{tabular}{|c|c|c|c|c|c|c|}
\hline \multirow[b]{2}{*}{ PARÂMETROS } & \multicolumn{3}{|c|}{ ÁREA A } & \multicolumn{3}{|c|}{ ÁREA B } \\
\hline & $\mathrm{CC}$ & n.m.s. & $\mathrm{CQ}$ & $\mathrm{CC}$ & n.m.s. & $\mathrm{CQ}$ \\
\hline \multicolumn{7}{|l|}{ Tempo de } \\
\hline Carregamento (s) & 605,50 & (NS) & 623,04 & 589,26 & (NS) & 606,50 \\
\hline \multicolumn{7}{|l|}{ Ciclos de } \\
\hline Carregamento & 23 & (NS) & 21 & 22 & (NS) & 23 \\
\hline \multicolumn{7}{|l|}{ Percurso de } \\
\hline Carregamento (m) & 128,68 & $(0,10)$ & 194,60 & 169,30 & $(0,30)$ & 226,20 \\
\hline Carga Líquida (t) & 9,311 & $(0,02)$ & 14,970 & 11,640 & $(5,40)$ & 15,704 \\
\hline \multicolumn{7}{|l|}{ Capacidade de Campo } \\
\hline Operacional $(\mathrm{t} / \mathrm{h})$ & 55,65 & $(0,43)$ & 87,19 & 71,12 & $(4,16)$ & 95,91 \\
\hline
\end{tabular}

Pela análise da Tabela 6, verifica-se comportamento semelhante entre as áreas experimentais $\mathrm{A}$ e B, nas quais os tratamentos não diferiram estatísticamente para as variáveis tempo e ciclos de carregamento. Isto indica que a presença do palhiço não afeta o tempo de carregamento da unidade transportadora, nem o número de ciclos necessários ao carregamento.

Por outro lado, a maior eficiência do processo de carregamento para cana queimada é caracterizada pela quantidade de matéria-prima carregada por ciclo. Embora o tempo e o número de ciclos possam ser considerados iguais para as duas situações, a carga por ciclo é 1,76 vezes maior para cana queimada ( $405 \mathrm{~kg} /$ ciclo - CC, $712 \mathrm{~kg} /$ ciclo - CQ) na área $\mathrm{A}$ e 1,29 vezes maior na área $\mathrm{B}(529 \mathrm{~kg} /$ ciclo - CC, $682 \mathrm{~kg} / \mathrm{ciclo}-\mathrm{CQ})$, mostrando um 
melhor aproveitamento da capacidade da garra da carregadora. Essa maior eficiência também visualizada na capacidade de campo operacional $(\mathrm{t} / \mathrm{h})$, visto que a situação com cana queimada apresentou diferenças significativas ao nível de $10 \%$ em relação a cana crua, para as duas áreas analisadas, conforme mostram a Tabela 6 e a Figura 3. A maior densidade de cana presente nos montes, em razão da ausência dos ponteiros, folhas e palhas explica estas diferenças.

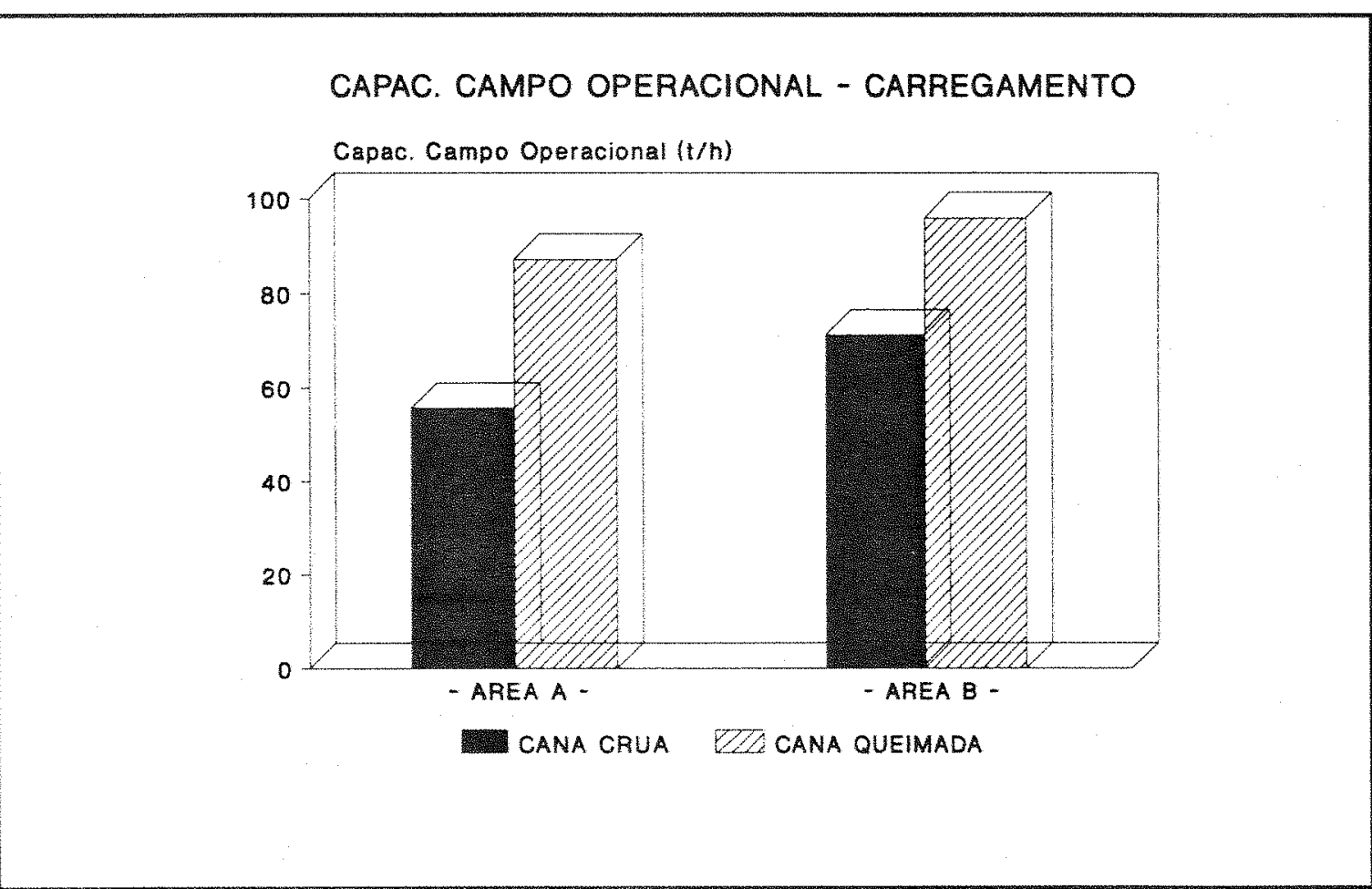

FIGURA 3 - Capacidade de campo operacional de carregamento - th - para as Áreas A e $B$ nas condições de cana crua e queimada. 


\subsubsection{Transporte}

Para a determinação do fluxo de transporte, utilizou-se os valores médios de velocidade fornecidos pela Usina para as condições locais, correspondentes aos veículos MB 2219: vazio $50 \mathrm{~km} / \mathrm{h}$ e carregado $40 \mathrm{~km} / \mathrm{h}$. Esses valores de velocidade são fornecidos para caminhões operando com cana queimada. Em razão da diferença observada entre as cargas para cana crua e queimada, e devido ao fato de que esta diferença pode alterar a velocidade média das unidades pela variação da razão potência/peso, optou-se por corrigir os valores de velocidade média para transporte da cana crua. Essa correção foi efetuada através da equação empírica proposta por ABAYNAYAKA, et al (1976) para estradas não pavimentadas, e utilizada por MILAN (1992), a qual expressa a velocidade $\mathrm{em} \mathrm{km} / \mathrm{h}$ considerando os efeitos dos parâmetros que influem no desempenho do caminhão: aclive, declive, curvatura, umidade do solo, profundidade dos buracos, largura da estrada e a razão potência-peso.

Para a aplicação da equação, considerou-se que todos os parâmetros permaneceram constantes, devido a manutenção das mesmas condições de tráfego entre as áreas experimentais e a indústria, excessão feita apenas à variabilidade entre a razão potência-peso. Portanto:

$$
\mathrm{V}(\mathrm{km} / \mathrm{h})=[\mathrm{a}+1,114] \times \frac{\text { Potencia }(\mathrm{CV})}{\text { Peso Total }(\mathrm{t})}
$$

onde:

$\mathrm{V}=$ velocidade do veículo

$a=$ parâmetros de trafegabilidade

Potência $(\mathrm{CV})=$ Potência nominal do veículo

Peso Total $(t)=$ Situação veículo vazio e carregado 
Os resultados obtidos pela aplicação da equação, são apresentados na Tabela 7.

TABELA 7 - Valores de velocidade fornecida e calculada para os veículos de transporte da matéria-prima, nas condições de cana crua (CC) e cana queimada (CQ).

\begin{tabular}{|c|c|c|c|c|c|c|c|}
\hline \multirow{3}{*}{ ÁREAS } & \multirow{3}{*}{$\begin{array}{c}\text { CONDIÇÕES DO } \\
\text { CANAVIAL }\end{array}$} & \multicolumn{6}{|c|}{ VELOCIDADES $(\mathrm{km} / \mathrm{h})$} \\
\hline & & \multicolumn{2}{|c|}{ V.CHEIO } & \multicolumn{2}{|c|}{ V.VAZIO } & \multicolumn{2}{|c|}{ V.MÉDIA } \\
\hline & & $\mathrm{F}$ & $\mathrm{C}$ & $\mathrm{F}$ & $\mathrm{C}$ & $\mathrm{F}$ & $\mathrm{C}$ \\
\hline \multirow[t]{2}{*}{ A } & $\mathrm{CC}$ & 40,0 & 42,6 & 50,0 & - & 45,0 & 46,3 \\
\hline & $\mathrm{CQ}$ & 40,0 & - & 50,0 & - & 45,0 & - \\
\hline \multirow[t]{2}{*}{ B } & $\mathrm{CC}$ & 40,0 & 41,4 & 50,0 & - & 45,0 & 45,7 \\
\hline & $\mathrm{CQ}$ & 40,0 & - & 50,0 & - & 45,0 & - \\
\hline
\end{tabular}

As modificações na velocidade só foram efetuadas para os veículos carregados com cana crua; as demais situações, por não alterarem a relação potência/peso, permaneceram constantes.

A Tabela 8 apresenta os dados referentes a capacidade operacional das unidades de transporte. Nela observa-se os valores de carga líquida transportadas, distância das áreas experimentais e o fluxo de transporte; este último foi determinado á partir da velocidade média dos caminhões apresentada na Tabela 7. 
TABELA 8 - Capacidade operacional do transporte da matéria-prima recolhida nas áreas experimentais, para as condições de cana crua (CC) e cana queimada (CQ).

\begin{tabular}{lllllll}
\hline & \multicolumn{3}{c}{ ÁREA A } & \multicolumn{3}{c}{ ÁREA B } \\
\cline { 2 - 7 } PARÂMETROS & CC & n.m.s. & CQ & CC & n.m.s. & CQ \\
\hline
\end{tabular}

Percurso de

Transporte $(\mathrm{km})$

\begin{tabular}{lllllll}
\hline Carga Líquida (t) & 9,311 & $(0,02)$ & 14,970 & 11,640 & $(5,40)$ & 15,704 \\
\hline
\end{tabular}

Fluxo de Transporte

$(\mathrm{t} . \mathrm{km} / \mathrm{h})$

431,10

$673,65 \quad 531,90$

706,68

(n.m.s.) = nivel mínimo de significância, Teste de Wilcoxon.

$\mathrm{NS}=$ não significativo (n.m.s. $>10 \%)$.

A análise da Tabela 8, permite observar que ocorreram diferenças significativas nas cargas líquidas transportadas nos tratamentos em ambas as áreas experimentais, verificando-se superioridade aos valores correspondentes a condição de cana queimada, justificável, da mesma forma que na operação de carregamento. A ausência de folhas verdes, palhas e ponteiros junto aos colmos, caracterizou o aumento da densidade de carga transportada, elevando os valores das cargas líquidas.

Pela pequena variação das velocidades médias, as diferenças em relação ao fluxo de transporte podem também ser atribuídas á densidade de carga. O fluxo de transporte é maior para cana queimada na razão de 1,57 e 1,35 respectivamente para as áreas experimentais A e B.

\subsection{Análise de Pós-Colheita}

Os resultados médios obtidos pela análise pós-colheita - perdas no campo, apresentados na Tabela $9 \mathrm{em}$ tha, correspondem às variáveis que expressam o potencial de 
matéria-prima e o resíduo que fica retido no campo após a colheita.

TABELA 9 - Quantificação das perdas pós-colheita em termos de colmos (CO); frações de colmos (FCO) e palhiço (PP), nas áreas experimentais, para as condições de cana crua (CC) e queimada (CQ).

\begin{tabular}{ccccc}
\hline & & CC & & CQ \\
\cline { 3 - 5 } ÁREAS & PARAMETROS & $(\mathrm{t} / \mathrm{ha})$ & n.m.s. & $(\mathrm{t} / \mathrm{ha})$ \\
\hline \multirow{2}{*}{$\mathrm{A}$} & CO & 0,58 & $(\mathrm{NS})$ & 0,97 \\
& FCO & 0,65 & $(4,31)$ & 0,34 \\
& PP & 7,40 & $(8,70)$ & 4,00 \\
\hline \multirow{2}{*}{ B } & CO & 0,33 & $(\mathrm{NS})$ & 0,27 \\
& FCO & 0,63 & $(5,91)$ & 0,55 \\
& PP & 8,40 & $(3,10)$ & 2,40 \\
\hline
\end{tabular}

(n.m.s.) = nível mínimo de significância, Teste de Wilcoxon

NS = não significativo (n.m.s.> 10\%)

As perdas de pós-colheita da matéria-prima industrializável podem ser caracterizads pela presença de colmos.(CO) que ficaram no campo após a catação e as frações de colmos (FCO) restantes na soqueira. As perdas referentes ao palhiço (PP), o qual pode ser utilizado para fins energéticos ou na alimentação de animais, referem-se á soma dos ponteiros e folhas verdes e secas que ficaram no campo.

Verifica-se que quanto á matéria-prima industrializável, não houve diferença significativa entre as condições de cana crua e queimada, para as áreas A e B, o que reflete a qualidade do trabalho da equipe de catação utilizada para estas condições, e verifica-se que, provavelmente, não houve influência do palhiço que sobrou sobre o solo nesta atividade.

As quantidades de frações de colmos apresentaram diferenças significativas para as condições de cana crua e queimada nas áreas experimentais. Uma possível 
explicação para este fato, seria a dificuldade por parte dos cortadores, de melhor visualizar o ponto de corte ideal nos colmos, devido à maior quantidade de folhas e palhas presentes na condição de cana crua.

As perdas correspondentes ao palhiço, apresentaram uma tendência definida em relação as áreas experimentais, cujos valores apresentam-se estatísticamente significativos. Para as duas áreas, os resultados referentes à cana crua foram superiores à condição de cana queimada, o que evidencia a vantagem na colheita de cana crua, na preservação da matéria vegetal para posterior aproveitamento.

O palhiço que ficou retido no campo, na forma de resíduos pós-colheita, representa uma considerável quantidade de biomassa vegetal, a qual poderia ser aproveitada para outros segmentos, através da recuperação e utilização desse material em substituição a outro mais nobre. Os valores obtidos nas áreas A e B, para a condição de cana queimada, são relativamente altos, o que permite supor que a queima a que foi submetido o canavial não foi de boa qualidade.

PERDAS POS-COLHEITA NO CAMPO

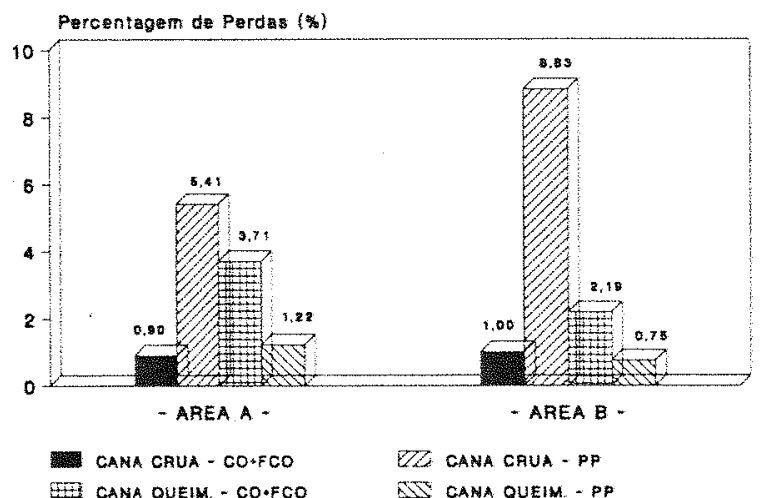

FIGURA 4 - Perdas de pós-colheitas no campo, em precentagem, relativas a produtividade, para as Áreas A e B, nas condições de cana crua e queimada. 
A Figura 4 apresenta as perdas totais de matéria-prima industrializável $(\mathrm{CO}+$ FCO) e quantidades de palhiço (PP), obtidas em relação a produtividade de colmos, para as duas áreas consideradas, nas condições de cana crua e cana queimada. Observa-se, como referência, a quantidade de matéria-prima e a biomassa vegetal perdidas no campo, em relação a massa total de colmos produzida.

Resultados semelhantes foram encontrados por FURLANI NETO (1984); FURLANI NETO et al (1984); PEIXOTO \& DELGADO (1988b) e ROSA et al (1993), os quais caracterizaram as diferentes formas de perdas de matéria-prima deixadas no campo.

Os índices porcentuais das perdas correspondentes ao palhiço encontrados neste trabalho, para colheita de cana sem queimar mostraram-se inferiores aos determinados por RIPOLI (1991); MOLINA JUNIOR (1991) e ABRAMO FILHO et al (1993), provavelmente por tratar-se de resíduos de colheita mecanizada em cana crua.

\subsection{Análise de Impurezas na Matéria-Prima}

$\mathrm{Na}$ Tabela 10 e Figura 5, encontram-se os valores médios porcentuais observados em relação a massa amostrada pela sonda, das variáveis referentes à impureza nas unidades de transporte. As amostras são caracterizadas pela presença de colmos (matéria-prima industrializáveis), folhas verdes e palhas (impurezas vegetais) e terra e pedras (impurezas minerais). 
TABELA 10 - Resultados médios da massa de: matéria-prima amostrada pela sonda (MAS) e porcentagens de matéria estranha vegetal (MEV), mineral (MEM) e colmos (MC) nas unidades de transportes para as condições de cana crua e cana queimada.

\begin{tabular}{ccccc}
\hline ÁREAS & PARÂMETROS & CC & n.m.s. & CQ \\
\hline \multirow{2}{*}{ A } & MAS (kg) & 10,93 & & 12,43 \\
& MEV (\%) & 15,00 & $(0,43)$ & 7,97 \\
& MEM (\%) & 0,61 & $(0,43)$ & 0,33 \\
& MC (\%) & 84,32 & $(0,43)$ & 91,70 \\
\hline \multirow{2}{*}{ B } & MAS (kg) & 9,38 & & 12,26 \\
& MEV (\%) & 15,40 & $(0,43)$ & 6,90 \\
& MEM (\%) & 1,13 & $(2,49)$ & 0,24 \\
& MC (\%) & 83,47 & $(0,43)$ & 92,85 \\
\hline
\end{tabular}

$($ n.m.s. $)=$ nivel minimo de significância, Teste de Wilcoxon

$\mathrm{NS}=$ não significativo (n.m.s.> 10\%)

A análise da Tabela 10, permite verificar que o tratamento com cana crua apresentou porcentuais de matéria estranha vegetal que diferiram estatísticamente em relação ao tratamento com cana queimada evidenciando, como era esperado, a ação da queima que antecedeu a colheita.

O indice de matéria estranha mineral também teve seus valores estatísticamente diferentes entre as condições de cana crua e queimada. Verifica-se que os maiores valores correspondem a cana crua, provavelmente devido a presença das folhas que ficaram junto aos colmos, às quais aderiram maiores quantidades de terra do que na condição de cana queimada. Este fator é importante para a qualidade da matéria-prima recebida na indústria, a qual deverá ser isenta de impurezas, principalmente as minerais, que oneram os custos de lavagem. 
Os valores correspondentes à percentagem de colmos presentes nas amostras apresentaram-se estatísticamente significativos. Observa-se que os valores mais expressivos correspondem a condição de cana queimada, verificando-se que a redução da matéria estranha vegetal possibilita maiores quantidades de matéria-prima (colmos) proveniente do campo.

A Figura 5 permite visualizar a aplicação dos índices percentuais sobre as cargas médias transportadas, conforme dados da Tabela 8. Para as quantidades percentuais verificadas para colmos transportados, obteve-se 7,851 t e 9,716 t para cana crua; 13,727 t e 14,581 t para cana queimada; matéria estranha mineral 0,057 t e 0,132 t para cana crua e 0,049 t e 0,037 t para cana queimada; matéria estranha vegetal 1,397 t e 1,793 t para cana crua e 1,193 t e 1,084 t para cana queimada, respectivamente nas áreas A e B.

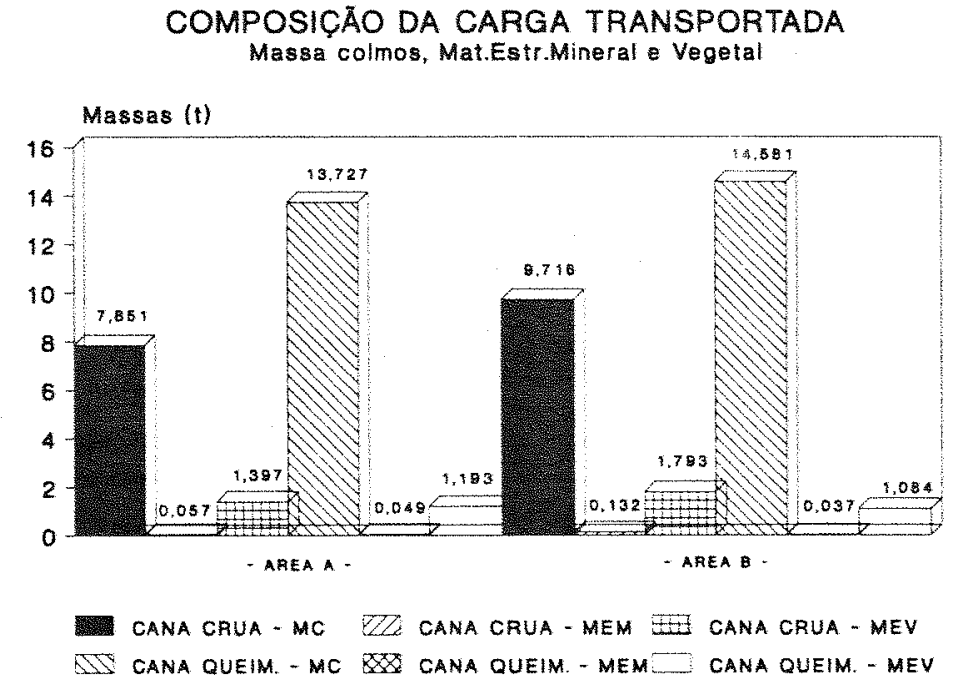

FIGURA 5 - Composição média da carga transportada, em toneladas, para as condições de cana crua e queimada nas Áreas A e B. 
Esses indices de impurezas surgem em proporções variáveis ligadas aos fatores específicos a área experimental, tais como textura do solo e ocorrência de chuvas, qualidade da queima, sistema de corte adotado, variedades com menor quantidade de folhas e principalmente os fatores ligados ao controle no rastelamento durante o carregamento, conforme discutido em CANA-DE-AÇÚCAR ... (1994).

Resultados semelhantes, relativos à incidência de impurezas minerais e vegetais, foram obtidos por BETANCOURT (1967); FERNANDES \& OLIVEIRA (1977); FURLANI NETO (1984), BELODI (1988) e SHAW \& BROTHERTON (1992).

\subsection{Análise do Teor de Bagaço na Matéria-Prima}

A Tabela 11 apresenta os resultados médios obtidos em percentagem para o teor de bagaço proveniente das amostras de matéria-prima coletadas junto às unidades de transporte. Os valores correspondentes aos demais parâmetros tecnológicos, encontram-se no Apêndice 1.

TABELA 11 - Resultados médios para o teor de bagaço contido na matéria-prima, a partir das amostras das unidades de transporte, para as condições de cana crua $(\mathrm{CC})$ e cana queimada (CQ).

\begin{tabular}{ccccc}
\hline ÁREAS & PARÂMETROS & CC & n.m.s. & CQ \\
\hline A & BAGAÇO \% CANA & 32,97 & $(5,28)$ & 27,65 \\
\hline B & BAGAÇO \% CANA & 36,00 & $(0,59)$ & 25,05 \\
\hline (n.m.s.) = nivel minimo de significância, Teste de Wilcoxon & & \\
NS = não significativo (n.m.s.> 10\%) & & &
\end{tabular}

O observa-se que os valores do teor de bagaço presente na matéria-prima, apresentaram diferenças significativas entre os tratamentos, constatando-se valor médio maior para a condição de cana crua, nas duas áreas estudadas. 
$\mathrm{Na}$ colheita de cana crua verificou-se índices elevados de bagaço, ou seja: 45,00 tha e 34,20 tha, considerando as quantidades médias estimadas de massas de colmo (Tabela 2). Para cana queimada, as quantidades de bagaço foram: 29,80 t/ha e 27,40 tha, respectivamente, para as áreas $\mathrm{A}$ e $\mathrm{B}$.

Esses resultados confrontados com os constantes da literatura, mostram-se relativamente semelhantes, quando se considera a colheita de cana-de-açúcar sem queima prévia, conforme se verifica em SILVA \& SILVA JUNIOR (1982); MELO et al (1988); RIPOLI (1991); CERQUEIRA LUZ \& ALOISI (1991).

\subsection{Determinação do Potencial Energético do Canavial}

Os resultados médios obtidos pela determinação dos poderes caloríficos superior (PCS), inferior (PCI) e útil (PCU), do palhiço (ponteiros, folhas verdes e palhas), em $\mathrm{kcal} / \mathrm{kg}$, encontram-se na Tabela 12 . Os valores correspondentes à umidade (\%) das frações do palhiço encontram-se no Apêndice 1. 
TABELA 12 - Resultados médios em $\mathrm{kcal} / \mathrm{kg}$, de poder calorífico superior (PCS), inferior $(\mathrm{PCI})$ e útil ( $\mathrm{PCU})$ do palhiço obtido nas áreas $\mathrm{A}$ e $\mathrm{B}$, para as condições de cana crua (CC) e cana queimada (CQ).

\begin{tabular}{|c|c|c|c|c|}
\hline & & $\mathrm{CC}$ & & $\mathrm{CQ}$ \\
\hline ÁREAS & PARÂMETROS & $\mathrm{kcal} / \mathrm{kg}$ & n.m.s. & $\mathrm{kcal} / \mathrm{kg}$ \\
\hline \multirow[t]{3}{*}{ A } & PCS & 4375,38 & $(1,65)$ & 4500,67 \\
\hline & $\mathrm{PCI}$ & 4036,80 & $(0,43)$ & 4162,09 \\
\hline & $\mathrm{PCU}$ & 1915,10 & (NS) & 1860,34 \\
\hline \multirow[t]{3}{*}{ B } & PCS & 4670,67 & $(1,65)$ & 4483,98 \\
\hline & $\mathrm{PCI}$ & 4332,28 & $(0,43)$ & 4145,40 \\
\hline & $\mathrm{PCU}$ & 1904,42 & (NS) & 1946,28 \\
\hline
\end{tabular}

$($ n.m.s. $)=$ nivel mínimo de significância, Teste de Wilcoxon

NS = não significativo (n.m.s. $>10 \%$ )

Pela análise da Tabela 12, observa-se que ocorreram diferenças estatísticamente significativas entre os tratamentos propostos, para os valores de PCS e PCI do palhiço, refletindo o fato de que a queima provocou pequenas diferenças absolutas em termos de poder calorífico para a massa de palhiço do canavial, Os valores de PCU, não apresentaram diferenças significativas.

O confronto entre os resultados observados para cana crua e queimada e os obtidos por outros autores, não representa interferências quanto ao maior ou menor valor de poder calorifico, tanto PCS como PCI. Verifica-se que os valores correspondentes ao PCU, mostraram-se menores, pois estão condicionados, mais à variação do grau de umidade e a quantidade do teor de fibra presentes nas frações analisadas, conforme discute OLIVEIRA (1982).

Outros autores, trabalhando com resíduos de colheita de cana-de-açúcar, obtiveram os seguintes valores: 


\begin{tabular}{lccc}
\hline \multicolumn{1}{c}{ AUTORES } & PCS & PCI & PCU \\
\cline { 2 - 4 } AGUILAR et al (1989) & 4774,00 & - & - \\
RIPOLI et al (1990a) & 4325,07 & 3852,83 & 1947,30 \\
MOLINA JR. (1991) & 4321,15 & 3982,57 & 2991,38 \\
\hline
\end{tabular}

A Tabela 13 e a Figura 6 apresentam os valores médios correspondentes ao potencial energético do palhiço (PEP) em Mcal/ha, obtido para as áreas e condições do estudo.

TABELA 13 - Determinação do potencial energético do palhiço (ponteiro - PO; folha verde - FV e palha - PA) - PEP (Mcal/kg) para as áreas experimentais nas condições de cana crua e cana queimada.

\begin{tabular}{|c|c|c|c|}
\hline & & $\mathrm{CC}$ & $\mathrm{CQ}$ \\
\hline ÁREAS & PARÂMETROS & Mcal/ha & Mcal/ha \\
\hline $\mathrm{A}$ & PEP & $(100) 63686,42$ & (48) 30851,58 \\
\hline B & PEP & (100) 50173,32 & (69) 34672,45 \\
\hline
\end{tabular}

Pela análise dos resultados verifica-se que os maiores valores são observados para a condição de cana crua nas áreas experimentais, aos quais atribuiu-se o índice 100; para a cana queimada os índices foram 48 e 69 , ou seja, houve uma redução de $52 \%$ e $31 \%$ do potencial energético do palhiço presente nas áreas A e B, respectivamente, acentuando-se a idéia de perda energética decorrente da queima dos canaviais.

Os resultados encontrados, são semelhantes aos obtidos por MOLINA JUNIOR (1991) e RIPOLI et al (1991), muito embora esses autores tenham estudado outras 
variedades, com diferentes idades e produtividades.

Pela Figura 6, verifica-se a participação das frações características do palhiço e a representação percentual de seus respectivos valores em Mcal/ha, considerando, o potencial energético total. Para as áreas estudadas verificou-se, na condição de cana crua, os seguintes valores de potencial energético: ponteiros $(\mathrm{PO})=22,0 \%$; folhas verdes $(\mathrm{FV})=50,0 \% \mathrm{e}$ palhas $(\mathrm{PA})=28,0 \%$, em cana queimada, ponteiros $(\mathrm{PO})=37,0 \%$; folhas verdes $(\mathrm{FV})=$ $60,0 \%$ e palhas $(\mathrm{PA})=3,0 \%$.

\section{POTENCIAL ENERGETICO DO PALHICOO $(\%)$}
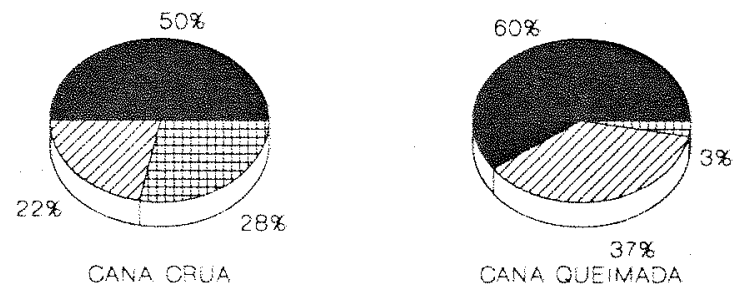

FV - Folhas Verdes QPO-ponteiros \#A-Palnas

FIGURA 6 - Potencial energético, em percentagem, das frações componentes do palhiço: ponteiros (PO), folhas verdes (FV) e palha (PA). Os valores refem-se à média para as áreas, nas condições de cana crua e cana queimada.

A Figura 6 demonstra a grande disponibilidade energética da biomassa proveniente dos resíduos vegetais. Verifica-se que, para a fração correspondente à palha, ocorreu uma sensivel redução de 28,0\% para 3,0\% devido à eliminação desse material pelo fogo. A palha poderia ser racionalmente utilizada como fonte de energia alternativa. 


\subsection{Avaliação de Desempenho Econômico dos Sistemas}

Para avaliação de desempenho econômico dos sistemas de colheita considerados, em cana crua e queimada, foi aplicada a equação geral que estabelece o balanço de renda líquida estimada - RLE em US\$/t, através da diferença entre os valores de receita (remuneração da cana-de-açúcar, o valor comercial do bagaço e do palhiço) e os custos envolvidos no processo de colheita estabelecido para os tratamentos.

Para a aplicação da equação, foram necessárias algumas considerações em relação a formação das receitas e dos custos. Para a composição da receita da cana-de-açúcar, foi aplicado o índice que representa o ágio, o qual estabelece o percentual correpondente à qualidade da matéria-prima que foi entregue na indústria; às receitas de bagaço e palhiço aplicaram-se as quantidades definidas em porcentagens obtidas nos experimentos para as condições propostas.

Aos parâmetros que determinaram os custos totais envolvidos nos processos, foram aplicados os respectivos valores obtidos para cada condição. O custo do corte manual da cana, refere-se ao preço pago pela tonelada de cana cortada. Para o carregamento condiderou-se a relação entre o custo horário da carregadora e a sua capacidade operacional, determinada em toneladas por hora. O transporte da matéria-prima, teve o custo estabelecido pelo produto da remuneração paga por quilometro rodado e a distância média de ciclo entre as áreas experimentais e o ponto de descarga, dividido pelo valor correspondente as cargas médias transportadas.

Os custos indiretos, representados pelos valores fixos, correspondentes à lavagem e catação da cana-de-açúcar, foram definidos por tonelada de cana lavada ou recolhida no campo.

Para o recolhimento e transporte do palhiço no campo, foram utilizados os valores indicados pela bibliografia (Apêndice 1, Tabelas XV a XVIII), a qual define um valor fixo para a remuneração, por tonelada recolhida e transportada, aplicado as quantidades 
percentuais contidas nas áreas experimentais.

A Tabela 14 apresenta a renda líquida estimada em US $\$ / t$, pela diferença estabelecida entre os valores correspondentes a receita e os custos totais aplicados aos dados do trabalho.

Pelo confronto entre os valores obtidos para RLE, nas condições de colheita de cana crua e queimada, verifica-se a ocorrência de pequena diferença, cerca de $17,0 \%$, em vantagem, para a condição relativa à colheita de cana queimada para ambas as áreas experimentais.

TABELA 14 - Valores médios determinados de Renda Líquida Estimada (RLE), em US\$/t, obtidos para as condições de cana crua e queimada, nas áreas experimentais A e B.

\begin{tabular}{|c|c|c|c|c|}
\hline \multirow{3}{*}{ PARÂMETROS } & \multirow{2}{*}{\multicolumn{2}{|c|}{$\frac{\text { ÁREA }}{\mathrm{A}}$}} & \multirow{2}{*}{\multicolumn{2}{|c|}{$\frac{\text { AREA }}{\mathrm{B}}$}} \\
\hline & & & & \\
\hline & $\mathrm{CC}$ & $\mathrm{CQ}$ & $\mathrm{CC}$ & $\mathrm{CQ}$ \\
\hline CANA US\$/t & 9,73 & 9,73 & 9,73 & 9,73 \\
\hline ÁGIO & 1,1386 & 1,1391 & 1,1227 & 1,2586 \\
\hline RECEITA DA CANA US\$/t & 11,08 & 11,08 & 10,92 & 12,25 \\
\hline BAGAÇOUS\$/t & 7,78 & 7,78 & 7,78 & 7,78 \\
\hline$\%$ BAGAÇO & 0,3297 & 0,2765 & 0,3600 & 0,2505 \\
\hline RECEITA DO BAGAÇO US\$/t & 2,57 & 2,15 & 2,80 & 1,95 \\
\hline $\mathrm{PALHICCO} \mathrm{US \$ /t}$ & 5,14 & 5,14 & 5,14 & 5,14 \\
\hline$\%$ PALHIÇO & 5,42 & 3,71 & 8,83 & 2,19 \\
\hline RECEITA DO PALHIÇO US\$/t & 0,28 & 0,19 & 0,45 & 0,11 \\
\hline TOTAL RECEITA (US\$/t) & 13,93 & 13.42 & 14,17 & 14,31 \\
\hline
\end{tabular}


TABELA 14 - (continuação) - Valores médios determinados de Renda Líquida Estimada (RLE), em US\$/t, obtidos para as condições de cana crua e queimada, nas áreas experimentais $\mathrm{A}$ e $\mathrm{B}$.

\begin{tabular}{|c|c|c|c|c|}
\hline \multirow{3}{*}{ PARÂMETROS } & \multicolumn{2}{|c|}{ ÁREA } & \multicolumn{2}{|c|}{ ÁREA } \\
\hline & \multicolumn{2}{|c|}{$\mathrm{A}$} & \multicolumn{2}{|c|}{$\mathrm{B}$} \\
\hline & $\mathrm{CC}$ & $\mathrm{CQ}$ & $\mathrm{CC}$ & $\mathrm{CQ}$ \\
\hline CORTE US\$/t & 0,86 & 0,74 & 0,86 & 0,74 \\
\hline CARREGAMENTO US\$/t & 33,12 & 33,12 & 33,12 & 33,12 \\
\hline CAP.OPERACIONAL t/h & 55,65 & 87,20 & 71,12 & 95,91 \\
\hline CUSTO OPERACIONAL US\$/t & 0,60 & 0,38 & 0,47 & 0,35 \\
\hline TRANSPORTE US $\$ / \mathrm{km}$ & 4,32 & 4,32 & 3,14 & 3,14 \\
\hline DISTÂNCIA km & 9,50 & 9,50 & 14,00 & 14,00 \\
\hline CARGA t & 9,311 & 14,970 & 11,642 & 15,704 \\
\hline CUSTO TRANSPORTE US\$/t & 4,41 & 2,74 & 3,78 & 2,80 \\
\hline LAVAGEM CANA US\$/t & 0,21 & 0,21 & 0,21 & 0,21 \\
\hline BITUCA US\$/t & 0,08 & 0,08 & 0,08 & 0,08 \\
\hline CUSTOS INDIRETOS US\$/t & 0,29 & 0,29 & 0,29 & 0,29 \\
\hline REC. PALHIÇO US $\$ / t$ & 3,55 & 3,55 & 3,55 & 3,55 \\
\hline$\%$ PALHIÇO & 5,42 & 3,71 & 8,83 & 2,19 \\
\hline CUSTO REC. PALHIÇO US\$/t & 0,19 & 0,13 & 0,31 & 0,08 \\
\hline TOTAL DOS CUSTOS US\$/t & 6,35 & 4,28 & 5,71 & 4,26 \\
\hline RLE (US\$/t) & 7,58 & 9,14 & 8,46 & 10,05 \\
\hline
\end{tabular}




\subsection{Considerações finais}

As avaliações preliminares realizadas nos canaviais serviram para quantificar as frações componentes da matéria-prima, dando idéia de grandeza e importância que representam no contexto energético, pelo volume de biomassa vegetal disponível.

O sistema alternativo de colheita semi-mecanizada de cana sem queima prévia, em relação ao tradicional com cana queimada, mostrou alguns incovenientes operacionais, não só no corte manual. Verificou-se um baixo rendimento dos cortadores de cana, um nível elevado de perdas em termos de frações de colmos deixados nas soqueiras, além de considerável quantidade de massa vegetal na forma de resíduos pós-colheita. A transferência da matéria-prima proveniente de canavial não queimado para á indústria, mensurada através da capacidade operacional de carregamento e transporte, foi significativamente menor, em termos de massa de cana carregada e transportada por hora. O carregamento na condição de cana crua, proporcionou elevados índices de matéria estranha mineral e vegetal junto a matéria-prima industrializável, influenciando nos custos de lavagem da cana e o transporte de retorno do resíduo mineral ao campo, o qual não foi avaliado neste trabalho. Entretanto, houve um acréscimo, em torno de $30 \%$ nos níveis de bagaço produzido nestas condições.

Por outro lado o percentual do potencial equivalente energético disponível no palhiço, em Mcal/ha, corresponde em média 58\% a mais na condição de cana crua do que na queimada, o que permite obter-se em média, ao equivalente em litros de óleo diesel $6408,81 /$ ha e $3688,21 /$ ha respectivamente.

Pela analise do sistema de colheita para a condição de cana crua, observa-se um maior custo imposto por esse processo. Entretanto, deve-se também analisar os aspectos benéficos, proporcionado em termos energéticos, através do aproveitamento da biomassa vegetal disponível e à melhoria das condições ambientais e sociais. 


\section{CONCLUSÕES}

Com base nos resultados, análises e objetivos propostos para esse estudo e nas condições em que os ensaios foram desenvolvidos, as seguintes conclusões podem ser formuladas:

- O desempenho operacional das operações de corte manual e de carregamento e transporte mecanizados para o sistema de colheita de cana crua, é inferior ao verificado para colheita de cana queimada.

- A operação de corte manual em cana crua, possibilita maiores índices de perdas de matéria-prima industrializável, em relação à mesma operação em cana queimada.

- O sistema de colheita alternativo em cana crua, aumentou a quantidade de resíduos vegetais sobre o solo em até $140 \%$, quando comparado ao sistema de colheita em cana queimada.

- O sistema de colheita em cana crua, acarreta maiores índices de impurezas minerais (232\%) e vegetais ( $40 \%$ ) transferidos à indústria, quando comparada ao sistema de colheita em cana queimada.

- O excedente de bagaço resultante da colheita em condição de cana crua, pode adicionar a receita valores de até $40 \%$, superior ao sistema tradicional de colheita em condição de cana queimada.

- O sistema de colheita semi-mecanizado em cana queimada apresentou desempenho econômico, aproximadamente $20 \%$ superior ao verificado no sistema de colheita em cana crua. 
REFERÊNCIAS BIBLIOGRÁFICAS

ABRAMO FILHO, J.; MATSUOKA, S.; SPERANDIO, M.L.; RODRIGUES, R.C.D.; MARCHETTI, L.L. Resíduo da colheita mecanizada de cana crua. Álcool e Açúcar, São Paulo, 67:23-5.

ABAYNAYAKA, S.W.; HIDE, H.; MOROSIVK, G.; ROBINSON, R. Tables for estimating vehicle operating costs on rural roads in developing countries. TRRL Laboratory Report, 723, 1976. 59p.

AGUILAR, A.; PENA, V.; FRIEDMAN, P.; BRITO, B. La combustion de los resíduos agrícolas de caña de azucar. Parte I. Características combustibles. Cuba Azucar, Havana, p.40, ene./mar. 1989.

ANUÁRIO ESTATÍSTICO DO BRASIL - 1992, Rio de Janeiro, 1992. v. 52, 1119p.

ANUÁRIO ESTATÍSTICO DO ESTADO DE SÃO PAULO. Fundação Sistema Estadual de Análise de Dados - SEADE. São Paulo, 2: 1-570, 1992.

ASSOCIAÇÃO BRASILEIRA DE NORMAS TÉCNICAS. Carvão vegetal: determinação do poder calorífico - Método de determinação. NBR-8633. Rio de Janeiro, 1984.13p.

BALBO, M. Corte de cana por metro $x$ toneladas convertidas em metro. STAB. Açúcar, Álcool e Subprodutos. Piracicaba, 5(3):38-9, 1987. 
BASSINELO, A.l.; FURLANI NETO, V.L.; MACEDO, N.; PARAZZI, C.; CASAGRANDE, J.C. Implicações agrícolas e industriais da colheita de cana crua. Araras, IAA/PLANALSUCAR, s.d. 55p.

BELODI, C.O. Processamento de cana sem desponte; experiência da açucareira Quatá. STAB. Açúcar, Álcool e Subprodutos, Piracicaba, 6(4/5):41-8, 1988.

BERTELLI, L.G. Dezesseis anos de Proálcool. STAB. Açúcar, Álcool e Subprodutos, Piracicaba, 11(1):19-20, set./out. 1992.

BETANCOURT, A.F. Materias estrañas en la cosecha de la caña de azícar. Boletin Oficial de la Asociaçón de Tecnicos Azucareros de Cuba, Havana, 22(2):3-29, 1967.

BRITO, J.O. \& BARRICHELLO, L.E.G. Aspéctos técnicos na utilização da madeira e carvão vegetal como combustiveis. In: SEMINÁRIO DE ABASTECIMENTO ENERGÉTICO INDUSTRIAL COM RECURSOS FLORESTAIS, 2., São Paulo, 1982. Anais. São Paulo, Secretaria da Ciência e Tecnologia, 1982. p.101-8.

CAMPOS, H. Estatística experimental não-paramétrica. 4a ed. Piracicaba, ESALQ, 1984. 343p.

CANA-DE-AÇUCAR, DIFICULDADES PARA SUPERAR O HOMEM. A Granja do Ano, Porto Alegre, 10(12):62-71, 1993/94.

COSTA FILHO, R.M. Queima da cana-de-açúcar. Boletim Técnico Copersucar, Piracicaba (10):8-12, 1979. 
CHURCHWARD, E.H. \& POULSEN, N.J. Review of harvestin developments. Proceedings of Australian Society of Sugar Cane Technologists, 1988. p.1-6.

DELGADO, A.A. Os efeitos da queima dos canaviais. STAB. Açúcar, Álcool e Subprodutos, Piracicaba, 3(6):42-5, jul./ago. 1985.

DELGADO, A.A. \& MAFRA, R.L. Cana com desponte: uma vantagem ou uma necessidade industrial? Revista Usineiro, São Paulo, 4(19):58-65, nov./dez. 1989.

DOAT, A. Le pouvoir calorifique des bois tropical. Bois et Forest des Tropiques, Paris, 172:33-48, mar./avr. 1977

FERNANDES, A.C. \& IRVINE, J.E. Comparação da produtividade da cana-de-açúcar por colheita mecanizada e por corte manual. STAB. Açúcar, Álcool e Subprodutos, Piracicaba, 4(6):112-6, jul./ago. 1986.

FERNANDES, A.C. \& OLIVEIRA. E.R. Impurezas em carregamento de cana-de-açúcar. Boletim Técnico Copersucar, Piracicaba, (5):5-8, set. 1977.

FERRARI, S.E.; VALSECHI, O.A; PARAZZI, C. A colheita da cana-de-açúcar sem desponte e o sistema de pagamento pela qualidade; um estudo preliminar. Brasil Açucareiro, Rio de Janeiro, 104(3/4):40-3, 1986.

FURLANI NETO, V.L. Incidência da matéria estranha e perdas no campo nos processos de corte manual e com colhedoras amontoadas em cana-de-açúcar (Saccharum spp). Piracicaba, 1984. 120p. (Mestrado - Escola Superior de Agricultura "Luiz de Queiroz"/USP). 
FURLANI NETO, V.L. A colheita da cana crua (sem queima) no Brasil. Piracicaba, ESALQ/USP, 1991. 31p.

FURLANI NETO, V.L.; FERNANDES, J.; STOLF, R.; COLETTI, J.T. Perdas no campo pelo sistema de corte mecanizado com canas inteiras amontoadas. Saccharum, São Paulo, 33(7):30-3. jul./ago. 1984.

FURLANI NETO, V.L.; MONTEIRO, H.; RIPOLI, T.C.C.; NOGUEIRA, R.R. Comparative analysis between green cane and burned cane: raw matter quality, cane losses, crop residue and chopper harvest performance. In: CONGRESS OF INTERNATIONAL SOCIETY OF SUGAR CANE TECHNOLOGISTS, 20., São Paulo, 1989. Proceedings. São Paulo, ISSCT, 1989. v.2, p. 1043-50.

GEMENTE, A.C.; FERRARI, S.E.; LOPES, C.H.; OLIVEIRA, E.R. Avaliação econômica comparativa entre a utilização agroindustrial de cana-de-açúcar despontada e com ponta em destilaria de álcool. STAB. Açúcar, Álcool e Subprodutos, Piracicaba, 3(5):27-34. mai./jun. 1985.

INSTITUTO DO AÇUCAR E DO ÁlCOOL. Ato no 32 de 28 de agosto de 1989. Diário Oficial, Brasília, 08 set 1989. p.1571-5.

KIEHL, E.J. Manual de edafologia: Relação solo água-planta. São Paulo. Ed. Ceres, 1979. 264p.

KIRCHHOFF, V.W.J.H. Queimadas na Amazônia e efeito estufa. São José dos Campos, Ed. Contexto, 1992. 118p. 
MELO, F.A.D.; BORBA, J.M.M.; PATERSON, M. Cana-de-açúcar integral e queimada sem desponte; resultados preliminares obtidos. Brasil Açucareiro, Rio de Janeiro, 106(5/6):33-37. 1988.

MILAN, M. Improving operational management of harvest, transport and mechanization for sugar cane in Brazil. Silsoe, 1992. 226p. (Ph. D. CRANFIELD INSTITUTE).

MOLINA JUNIOR, W.F. Enfardamento de resíduos de colheita de cana-de-açúcar (Saccharum spp). Avaliação dos desempenhos operacional e econômico. Piracicaba, 1991. 101p. (Mestrado - Escola Superior de Agricultura "Luiz de Queiroz"/USP).

MONTEIRO, H.; PEXE, C.A.; BASSINELO, J.L.; RIPOLI, T.C.C. Matéria estranha; custos e técnicas de sua diminuição na colheita. Álcool \& Açúcar, São Paulo, 2(6):20-6, set./out. 1982.

MUTTON, M.J.R.; STUPIELLO, J.P.; MUTTON, M.A.; BARBOSA, J.C. Consequências das impurezas minerais na avaliação da qualidade da cana. STAB. Açúcar, Álcool e Subprodutos, Piracicaba, 10(4):17-22. mar./abr. 1992.

NOA, H. La caña de azúcar como base de un desarollo agro-industrial postenible. In: CONFERENCIA MUNDIAL SOBRE O DESENVOLVIMENTO E O MEIO AMBIENTE. Rio de Janeiro. 1992. Trabalhos apresentados. Rio de Janeiro, 1992. p 12-15. 
OLIVEIRA, D.T. \& BULLIO, M.T. Aspectos técnicos-econômicos do corte e moagem da cana com ponta. STAB. Álcool, Açúcar e Subprodutos, Piracicaba, 7(1):39-42. 1988.

OLIVEIRA, E.R. Bagaço de cana: um combustivel que ainda não recebeu a devida atenção. Álcool \& Açúcar, São Paulo, 2(4):10-9. mai./jun. 1982.

PAYNE, J.H. Sugar and energy losses in burned cane. International Sugar Journal, London, 88(1054):191-2, Oct. 1986.

PEIXOTO, A.A. \& DELGADO, F.R.M.C.R. Manejo da colheita: I. Rendimentos de corte e embarque, com eitos de 5 e 7 linhas. Brasil Açucareiro, Rio de Janeiro, 106(2):33-37. 1988.

PEIXOTO, A.A. \& DELGADO, F.R.M.C.R. Manejo da colheita: Il. Indices de impurezas na matéria-prima, com o corte em eitos de 5 e 7 linhas. Brasil Açucareiro, Rio de Janeiro, 106(3):13-7, 1988a.

PEIXOTO, A.A. \& DELGADO, F.R.M.C.R. Manejo da colheita: III. Perdas de cana no campo, com o corte em eitos de 5 e 7 linhas. Brasil Açucareiro, Rio de Janeiro. 106(3):18-21, 1988b.

PEREIRA, V. Avaliação da nova sistemática de corte de cana implantada na região de Ribeirão Preto, na safra 83/84. STAB. Açúcar, Álcool e Subprodutos, Piracicaba, 2(2):16-21, nov./dez. 1983 . 
RIPOLI, T.C.C. Modelagem de desempenho operacional de carregadora auto propelida para cana-de-açúcar (Saccharum spp). Yiracicaba, 1986. 102p. (Mestrado - Escola Superior de Agricultura "Luiz de Queiroz"/USP).

RIPOLI, T.C.C. "Fogo na Palha?". Notícias da ESALQ. ESALQ/USP, Piracicaba, 1(5):2-3, nov. 1988 .

RIPOLI, T.C.C. Utilização do material remanescente de colheita de cana-de-açúcar (Saccharum spp.). Equacionamento dos balanços energético e econômico. Piracicaba, 1991. 150p. (Livre-Docência - Escola Superior de Agricultura "Luiz de Queiros"/USP).

RIPOLI, T.C.C.; RIGHI. J.C.; PEXE, C.A. Estudo comparativo entre três métodos de corte de cana-de-açúcar. In: Seminário Copersucar da Agroindústria Açucareira, 3., Águas de Lindóia, 1975. Anais. São Paulo, Copersucar, p. 335-44.

RIPOLI, T.C.C.; MILAN, M.; MIALHE, L.G.; FAGANELLO, B.F.; MONTEIRO, H.; FURLANI NETO, V.L. Carregamento mecânico: Ensaios com tipos de eitos e recolhedor de cana. In: CONGRESSO NACIONAL DA STAB, 3., São Paulo, 1984. p.135-39.

RIPOLI, T.C.C. \& MIALHE, L.G. Colheita manual vs. colheita mecanizada de cana-de-açúcar. STAB. Açúcar e Álcool e Subprodutos, Piracicaba, 5(3):27-37, jan./fev. 1987. 
RIPOLI, T.C.C. \& PARANHOS, S.B. Cana-de-açúcar: colheita. In: PARANHOS, S.B., coord. Cana-de-açúcar: cultivo e utilização. Campinas, Fund. Cargill, 1987. p.517-97.

RIPOLI, T.C.C.; MIALHE, L.G.; BRITO, J.O. Queima de canavial; o desperdício não mais admissivel! Álcool \& Açúcar, São Paulo, (54):18-23, jul./ago, 1990.

RIPOLI, T.C.C.; MOLINA JUNIOR, W.F.; NOGUEIRA, M.C.S.; MATOS, J.R. Equivalente energético do palhiço da cana-de-açúcar. In: CONGRESSO BRASILEIRO DE ENGENHARIA AGRÍCOLA, Piracicaba, 1990. Resumos. Piracicaba, FEALQ/ SBEA, 1990a. p.26.

RIPOLI, T.C.C., MOLINA JUNIOR, W.F.; STUPIELLO, J.P.; NOGUEIRA, M.C.; SACCOMANO, J.B. Potencial energético de residuos de cosecha de la caña verde. STAB. Álcool, Açúcar e Subprodutos, Piracicaba, 10(1):22-6. 1991.

RIPOLI, T.C.C., MOLINA JR., W.F.; COELHO, J.L.D.; SACCOMANO, J.B. Estudio sobre enfardamiento de resíduos de cosecha de caña verde. STAB. Álcool, Açúcar e Subprodutos, Piracicaba, 10(1):29-32. 1991a.

RIPOLI, T.C.C. \& VILLANOVA, N. A. Colheita mecanizada da cana-de-açúcar: novos desafios. STAB. Açúcar, Álcool e Subprodutos, Piracicaba, 11(1):28-31. set./out. 1992.

ROSA, R.F.; MORAES, A.R.; GLÍRIA, N.A. Perdas na colheita manual da cana-de-açúcar com carregamento mecânico. STAB. Açúcar e Álcool e Subprodutos, Piracicaca, 11(3):25-8. 1993. 
RUIZ, A.G. \& OROSCO, J.G. Sistema Cubano de cosecha en cana verde. In: SEMANA DE ATUALIZAÇÃO EM CANA-DE-AÇUCAR - TECNOCANA, Araras, 1992. $17 \mathrm{p}$.

SILVA, G.A.; SILVA JUNIOR J.D.; CEBALLOS, R.A. Utilização da cana com ponta e total na produção de açúcar, álcool e energia. Brasil Açucareiro, Rio de Janeiro, 100(6):28-35. 1982.

SHAW, G.R. \& BROTHERTON, G.A. Green cane harvesting - A dilema. Proceedings of Australina Society of Sugar Cane Technologists. 1992. p.1-7.

STUPIELLO, J.P. Alguns aspectos da qualidade da matéria-prima. STAB. Açúcar, Álcool e Subprodutos, Piracicaba, 7(3/5):52-4, jun./jul. 1989.

ZULAUF, W.E.; CAPORALI, S.A.; VIDEIRA, R.M. Cálculo preliminar da energia liberada anualmente na queima dos canaviais brasileiros. In: SIMPÓSIO SOBRE QUEIMA DE PALHA DE CANAVIAIS, 2., Araraquara, 1985. p. 1-7. 
APÊNDICE 1

\section{DADOS ORIGINAIS DE CAMPO, LABORATÓRIOS E ECONÔMICOS}

Os dados apresentados neste Apêndice referem-se áqueles obtidos no campo,

laboratórios e fornecidos pela Usina Costa Pinto e Associação dos Plantadores de Cana do Estado de São Paulo. 
TABELA I - CARACTERILACAO DA MATERIA-PRIMA COLHIDA MANUALMENTE:

Numero de colnos/2n lineares - No Numero medio de internodios/col $-n$;

Diametro medio dos colmos - D; Comprinerto medio dos colmos - $C_{;}$Massa

media de colmos/a linear - Co; de ponteiros - Po; de folhas verdes - Fy e

de palhas - Pa; Espacamento edio e o Porte do canavial para as condicoes

de cana crua quejada nas areas experimentais.

\begin{tabular}{|c|c|c|c|c|c|c|c|c|c|c|c|c|}
\hline AREA & COND & U.E. & No & $n$ & $D(\mathrm{~m})$ & $c(\mathrm{c})$ & Co $(\mathrm{kg})$ & Po (kg) & $F v(k q)$ & $\mathrm{Pa}(\mathrm{kg})$ & Esp $\{1\}$ & PeEreto \% \\
\hline \multirow{5}{*}{$A$} & \multirow{5}{*}{$C C$} & 1 & 19 & 16 & 25.40 & 253 & 14.000 & 1.050 & 1.820 & 0.950 & 1.10 & 86.70 \\
\hline & & 2 & 17 & 17 & 27.10 & 286 & 14.700 & 0.750 & 2.015 & 1.250 & 1.15 & 83.30 \\
\hline & & 3 & 14 & 17 & 27.00 & 259 & 12.100 & 0.800 & 1.700 & 0.850 & 1.10 & 74.10 \\
\hline & & 4 & 17 & 16 & 25.50 & 234 & 13.100 & 0.750 & 1.590 & 0.800 & 1.15 & 100.00 \\
\hline & & 5 & 20 & 19 & 29.70 & 273 & 21.250 & 1.060 & 2.155 & 0.750 & 1.10 & 100.00 \\
\hline \multirow{5}{*}{8} & \multirow{5}{*}{$C C$} & 1 & 26 & 14 & 24.60 & 183 & 12.100 & 0.575 & 1.500 & 0.850 & 1.15 & 100.00 \\
\hline & & 2 & 25 & 14 & 24.70 & 169 & 10.075 & 0.375 & 1.550 & 1.050 & 1.00 & 100.00 \\
\hline & & 3 & 21 & 13 & 24.60 & 162 & 8.025 & 0.350 & 0.850 & 0.800 & 1.10 & 100.00 \\
\hline & & 4 & 20 & 15 & 24.60 & 171 & 8.525 & 0.650 & 1.475 & 0.800 & 1.10 & 100.00 \\
\hline & & 5 & 32 & 14 & 24.90 & 174 & 13.600 & 0.840 & 1.575 & 1.250 & 1.00 & 100.00 \\
\hline \multirow{5}{*}{$A$} & \multirow{5}{*}{$C O$} & 1 & 19 & 14 & 23.60 & 234 & 10.600 & 0.560 & 1.375 & 0,080 & 1.10 & 86.70 \\
\hline & & 2 & 21 & 16 & 25,40 & 251 & 13.600 & 0.760 & 1.400 & 0.045 & 1.20 & 96,00 \\
\hline & & 3 & 16 & 16 & 25.70 & 258 & 11.150 & 0.795 & 1.225 & 0.018 & 1.15 & 95.60 \\
\hline & & 4 & 17 & 15 & 24.80 & 252 & 10.000 & 0.533 & 0.810 & 0.040 & 1.10 & 76.00 \\
\hline & & 5 & 24 & 15 & 24.50 & 229 & 13.900 & 0.600 & 0.830 & 0.050 & 1.15 & 87.00 \\
\hline \multirow{5}{*}{ E } & \multirow{5}{*}{$C Q$} & 1 & 26 & 14 & 23.40 & 174 & 10.815 & 0.750 & 0.875 & 0.040 & 1.20 & 100.00 \\
\hline & & 2 & 24 & 14 & 23.60 & 181 & 10.985 & 0.425 & 0.813 & 0.025 & 1.05 & 100.00 \\
\hline & & 3 & 27 & 14 & 23.70 & 179 & 12.210 & 0.815 & 0.815 & 0.090 & 1.10 & 100.00 \\
\hline & & 4 & 30 & 14 & 22.10 & 151 & 10.988 & 0.840 & 1.825 & 0.075 & 1.05 & 100.00 \\
\hline & & 5 & 30 & 14 & 24.30 & 180 & 15.290 & 0.940 & 1.450 & 0.020 & 1.00 & 100.00 \\
\hline
\end{tabular}




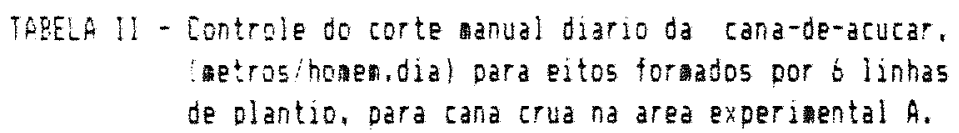

\begin{tabular}{|c|c|c|c|c|}
\hline \multirow{4}{*}{$\begin{array}{c}\text { Unidade } \\
\text { Experimental }\end{array}$} & \multicolumn{3}{|c|}{ PER10005 } & \multirow{4}{*}{ TOTAL DIARIO/HOMEM } \\
\hline & \multicolumn{3}{|c|}{ - } & \\
\hline & 1 & 2 & 3 & \\
\hline & & etr & & \\
\hline 1 & 17.50 & 19.80 & 21.20 & 58.50 \\
\hline 2 & 16.70 & 13.40 & 19.00 & 49.10 \\
\hline 3 & 14.40 & 13.80 & 19,30 & 47.50 \\
\hline 4 & 13,30 & 13.30 & 17.50 & 44.10 \\
\hline 5 & 15.40 & 29.40 & 20.40 & 65.20 \\
\hline 6 & 15.80 & 11.40 & 13.80 & 41.00 \\
\hline 7 & 16.30 & 8.50 & 12.00 & 36.80 \\
\hline 8 & 16.70 & 22.90 & 20.50 & 60.10 \\
\hline 9 & 6.00 & 13.20 & 9.50 & 28.70 \\
\hline 10 & 8.30 & 18.70 & 10.80 & 37,80 \\
\hline 11 & 19.70 & 14.20 & 14.50 & 48.40 \\
\hline 12 & 11.40 & 10.00 & 10.50 & 31.90 \\
\hline 13 & 14.20 & 7.50 & 9.30 & 31.00 \\
\hline 14 & 9.00 & 11.30 & 7.40 & 27.70 \\
\hline 15 & 5.30 & 4.20 & 6.50 & 16.00 \\
\hline 16 & 19.10 & 6.80 & 5.30 & 31.20 \\
\hline 17 & 16.90 & 4.60 & 10.70 & 32.20 \\
\hline 18 & 10.70 & 11.00 & 10.80 & 32.50 \\
\hline 19 & 14.30 & 12.50 & 15.00 & 41.80 \\
\hline 20 & 21.00 & 13.90 & 15.50 & 50.40 \\
\hline 21 & 18.10 & 10.80 & 20.80 & 49.70 \\
\hline 22 & 14.00 & 9.90 & 7.90 & 31.80 \\
\hline 23 & 12.40 & 6.80 & 8.80 & 28.00 \\
\hline 24 & 11.70 & 10.40 & 8.90 & 31.00 \\
\hline 25 & 10.90 & 15.90 & 8.80 & 35.60 \\
\hline 26 & 12.50 & 12.80 & 13.10 & 38.40 \\
\hline 27 & 14.40 & 16.10 & 17.00 & 47.50 \\
\hline 28 & 6.50 & 13.80 & 14.30 & 34.60 \\
\hline 29 & 15.90 & 13.40 & 11.30 & 40.60 \\
\hline 30 & 15.20 & 18.10 & 19.30 & 52.60 \\
\hline 31 & 13.90 & 19.00 & 19.90 & 52.70 \\
\hline 32 & 14.00 & 19.80 & 15.90 & 49.70 \\
\hline MEDIAS & 13.79 & 13.35 & 13.61 & 40.75 \\
\hline & 1 & 2 & 3 & 4 \\
\hline
\end{tabular}


TABELA 111 - Controle do corte manual diario da cana-de-acucar. (netros/honeadia) para eitos fornados por 6 linhas de plantio, para cana crua na area experimental 8.

\begin{tabular}{|c|c|c|c|c|}
\hline \multirow{2}{*}{$\begin{array}{c}\text { Unidade } \\
\text { Experiontal }\end{array}$} & \multicolumn{3}{|c|}{$P E R 10005$} & \multirow[b]{2}{*}{ TOTAL DIARIO/HOMEK } \\
\hline & 1 & ${ }^{2}$ & 3 & \\
\hline 1 & 12.30 & 16.40 & 21.60 & 50.30 \\
\hline 2 & 12.20 & 20.50 & 19.10 & 51.80 \\
\hline 3 & 12.30 & 17.70 & 16.40 & 46.40 \\
\hline 4 & 10.40 & 17.00 & 11.10 & 38.50 \\
\hline 5 & 15,00 & 18.20 & 14.80 & 48.00 \\
\hline$b$ & 8.40 & 12.10 & 10.70 & 31.20 \\
\hline 7 & 9.00 & 9.80 & 9.10 & 27.90 \\
\hline 8 & 8.60 & 10.10 & 8.40 & $27 \times 10$ \\
\hline 9 & 11.00 & 16.00 & 11.80 & 38.90 \\
\hline 10 & 12.30 & 17.30 & 24.10 & 53.70 \\
\hline 11 & 15,70 & 28.10 & 16.00 & 59.80 \\
\hline 12 & 15.60 & 16.80 & 13.10 & 45.50 \\
\hline 13 & 39.00 & 20.10 & 21.60 & 80.70 \\
\hline 14 & 15.00 & 25.00 & 21.70 & 61.70 \\
\hline 15 & 9.40 & 12.30 & 13.10 & 34.80 \\
\hline 16 & 8.00 & 13.80 & 17.70 & 39.50 \\
\hline 17 & 4.00 & 11.30 & 7.00 & 22.30 \\
\hline 18 & 8.00 & 15.30 & 16.10 & 39.40 \\
\hline 19 & 7.30 & 11.20 & 9.00 & 27.50 \\
\hline 20 & 12.40 & 15.50 & 11.60 & 39.50 \\
\hline 21 & 6.80 & 11.30 & 7.50 & 25.60 \\
\hline 22 & 10.70 & 11.40 & 7.20 & 29.30 \\
\hline 23 & 10.30 & 10.40 & 7.50 & 28.20 \\
\hline 24 & 12.60 & 21.70 & 7.30 & 41.60 \\
\hline 25 & 11.40 & 16.30 & 11.30 & 39.00 \\
\hline 26 & 10.10 & 18.70 & 9.70 & 38.50 \\
\hline 27 & 11.50 & 15.90 & 9.80 & 37.20 \\
\hline 28 & 11.90 & 19.50 & 14.30 & 45.70 \\
\hline 29 & 10.80 & 22.70 & 12.40 & 45.90 \\
\hline 30 & 15.50 & 36.70 & 19.20 & 61.40 \\
\hline 31 & 29.70 & 12.80 & 18.50 & 91.00 \\
\hline 32 & 13.00 & 28.20 & 23.50 & 64.70 \\
\hline 3 & 9.50 & 20.90 & 13.50 & 43.90 \\
\hline 34 & 20.20 & 19.10 & 15.90 & 55.20 \\
\hline 35 & 15.00 & 24.90 & 23.50 & 63.40 \\
\hline 36 & 26.40 & 34.80 & 16.80 & 78.00 \\
\hline 37 & 14.60 & 19.90 & 13.00 & 47.50 \\
\hline 38 & 31.90 & 23.90 & 16.10 & 71.90 \\
\hline 39 & 15.10 & 15.20 & 10.20 & 40.50 \\
\hline 40 & 7.10 & 13.10 & 14.70 & 34.90 \\
\hline 41 & 12.50 & 11.90 & 11.00 & 35.30 \\
\hline 42 & 32.60 & 18.10 & 9.70 & 60.40 \\
\hline MEDIAS & 13.93 & 18.38 & 13.97 & 46.27 \\
\hline
\end{tabular}


TAEEL IV - Controle do corte nanual diario da cana-de-acucar,
(metroshowen dia) para eitos formados por o linhas
de plantio, para cana queinada na area experimental A.

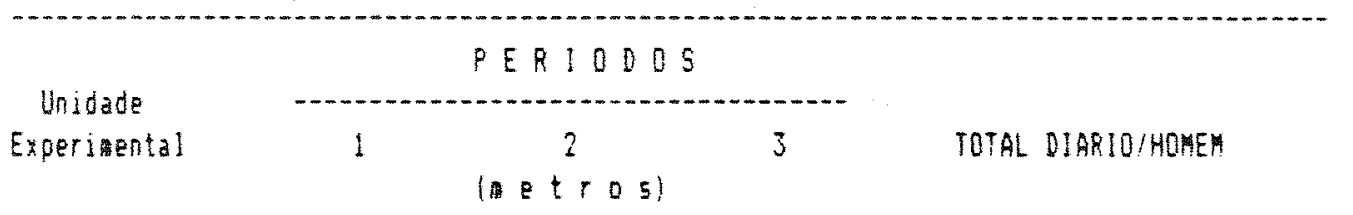

\begin{tabular}{|c|c|c|c|c|}
\hline 1 & 15.90 & 12.20 & 18.50 & 46.60 \\
\hline 2 & 17,30 & 10.60 & 26.00 & 53.90 \\
\hline 3 & 20.60 & 21.70 & 19.20 & 61.50 \\
\hline 4 & 17.90 & 24.70 & 14.00 & 56.60 \\
\hline 5 & 35.60 & 25.80 & 34,50 & 95.30 \\
\hline 6 & 20.90 & 25.10 & 23.00 & 69.00 \\
\hline 7 & 23.00 & 27.10 & 29.00 & 79.10 \\
\hline 8 & 29.60 & 27.00 & 33.50 & 90.10 \\
\hline 9 & 21.60 & 18.60 & 21.00 & $\$ 1.20$ \\
\hline 10 & 23.40 & 25.80 & 25.50 & 74.70 \\
\hline 11 & 25.40 & 27.10 & 25.00 & 77.50 \\
\hline 12 & 47.50 & 40.40 & 0.00 & 97.90 \\
\hline 13 & 24.90 & 30.50 & 30.00 & 85.40 \\
\hline 14 & 19.40 & 22.00 & 19.40 & 60.80 \\
\hline 15 & 26.40 & 29,30 & 21.00 & 76.70 \\
\hline 16 & 38.70 & 41.70 & 20.50 & 100.90 \\
\hline 17 & 50.50 & 22.30 & 0.00 & 72.80 \\
\hline 18 & 19.10 & 32.00 & 34,30 & 85.40 \\
\hline 19 & 19.20 & 36.80 & 17.20 & 73.20 \\
\hline 20 & 32.60 & 25.20 & 12.50 & 70.30 \\
\hline 21 & 26.00 & $30 \times 10$ & 11.00 & 67.10 \\
\hline 22 & 28.70 & 33.40 & 23.60 & 85.70 \\
\hline 23 & 46.80 & 25.40 & 23.60 & 95.80 \\
\hline 24 & 25.90 & 21.80 & 17.50 & 65.20 \\
\hline 25 & 55.30 & 36.20 & 48.00 & 139.50 \\
\hline 26 & 38.60 & 34.90 & 27.90 & 101.40 \\
\hline 27 & 45.90 & 37.30 & 50.00 & 133.20 \\
\hline 28 & 34.50 & 32.70 & 33.50 & 100.70 \\
\hline 29 & 35.80 & 36.50 & 40.00 & 112.30 \\
\hline 30 & 34.10 & 13.10 & 23.30 & 70.50 \\
\hline 3 & 32.00 & 33.70 & 14.60 & 80.30 \\
\hline 32 & 38.90 & 39.70 & 43.90 & 122.50 \\
\hline 53 & 23.60 & 24.50 & 21.50 & 69.60 \\
\hline 34 & 51.00 & 34.00 & 59.40 & 143.40 \\
\hline 35 & 40.00 & $22 \times 20$ & 46.60 & 108.80 \\
\hline 36 & 44.40 & 33.30 & 31.00 & 108.70 \\
\hline 37 & 25.50 & 32.00 & 14.00 & 71.50 \\
\hline 38 & 22.90 & 17.70 & 26.60 & 67.20 \\
\hline 39 & 20.60 & 47.20 & 20.00 & 87.80 \\
\hline 40 & 22.10 & 19.50 & 22.00 & 63.60 \\
\hline MEDIAS & 30.54 & 28.28 & 25.53 & 84.34 \\
\hline
\end{tabular}


TABELA V - Controle do corte anual diario da cana-de-acucar.

(netros/homen.dia) para eitos forados por 6 linhas

de plantio para cana queliada no area experiaental 8.

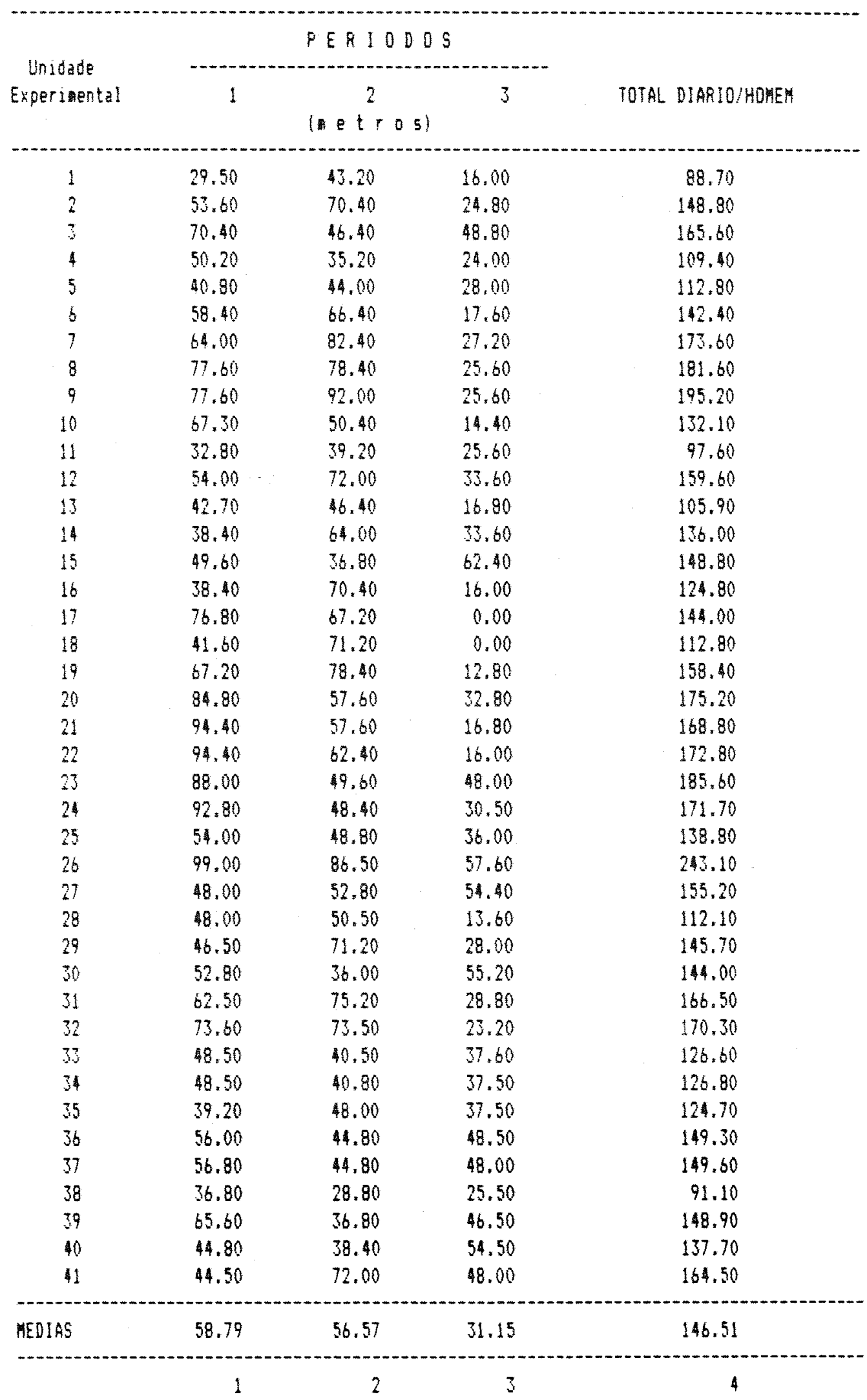


TABELA VI - Dperaca de carreqanento e transporte da nateria-oraa: Deterninacoes de teados - ( (5):

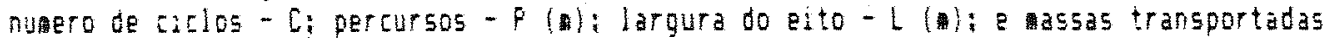

- MT (t) da natera-priaz recolhida nas areas experimentajs con cana crua.

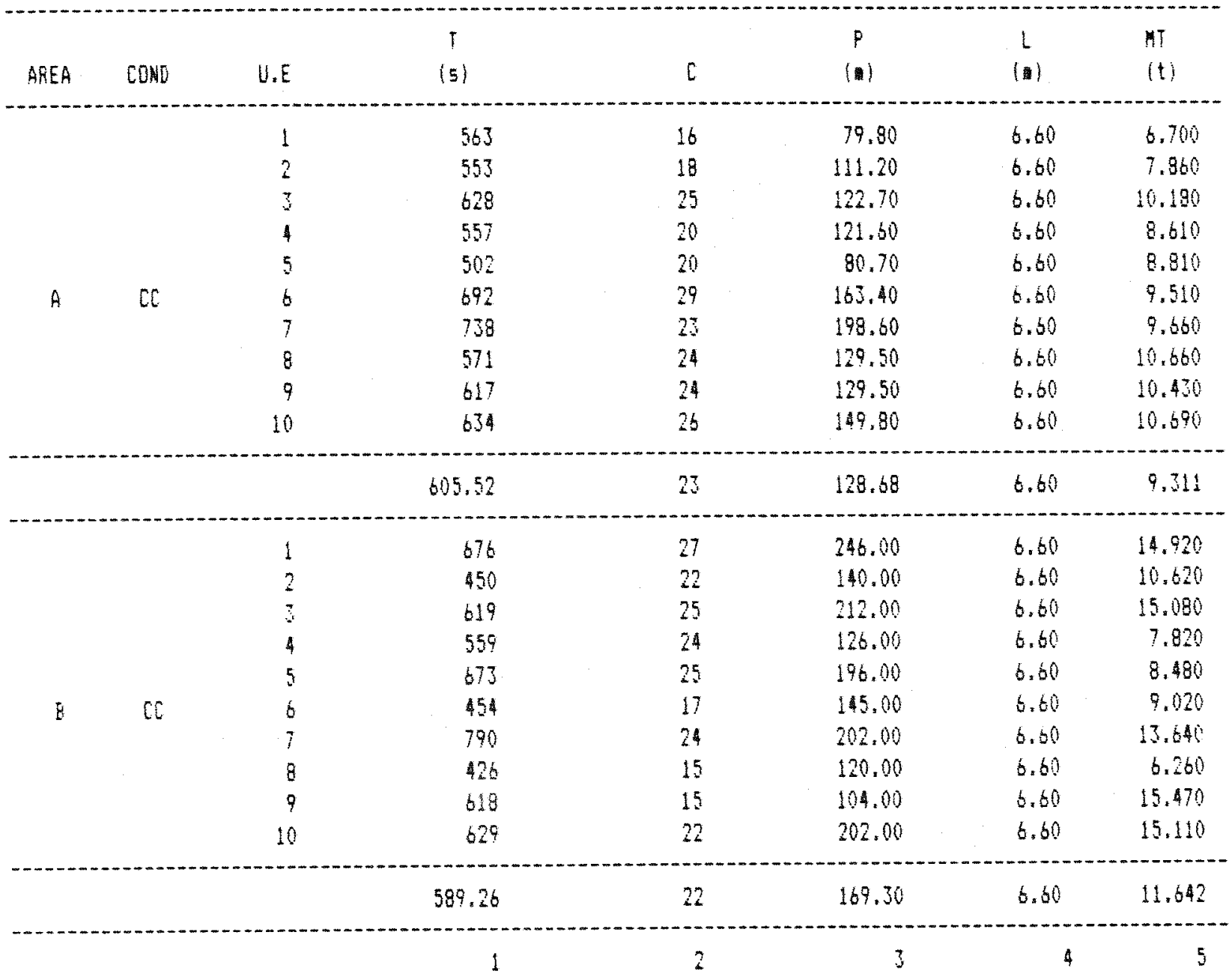


TABELA VI - (continuacao) - Dperacao de carregamento e transporte da materia-prina: Deter macoes de tenpos

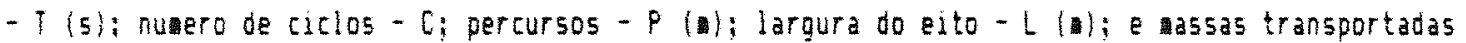

- MT (t) da ateria-prina recolhida nas areas experiontais col cana queinada.

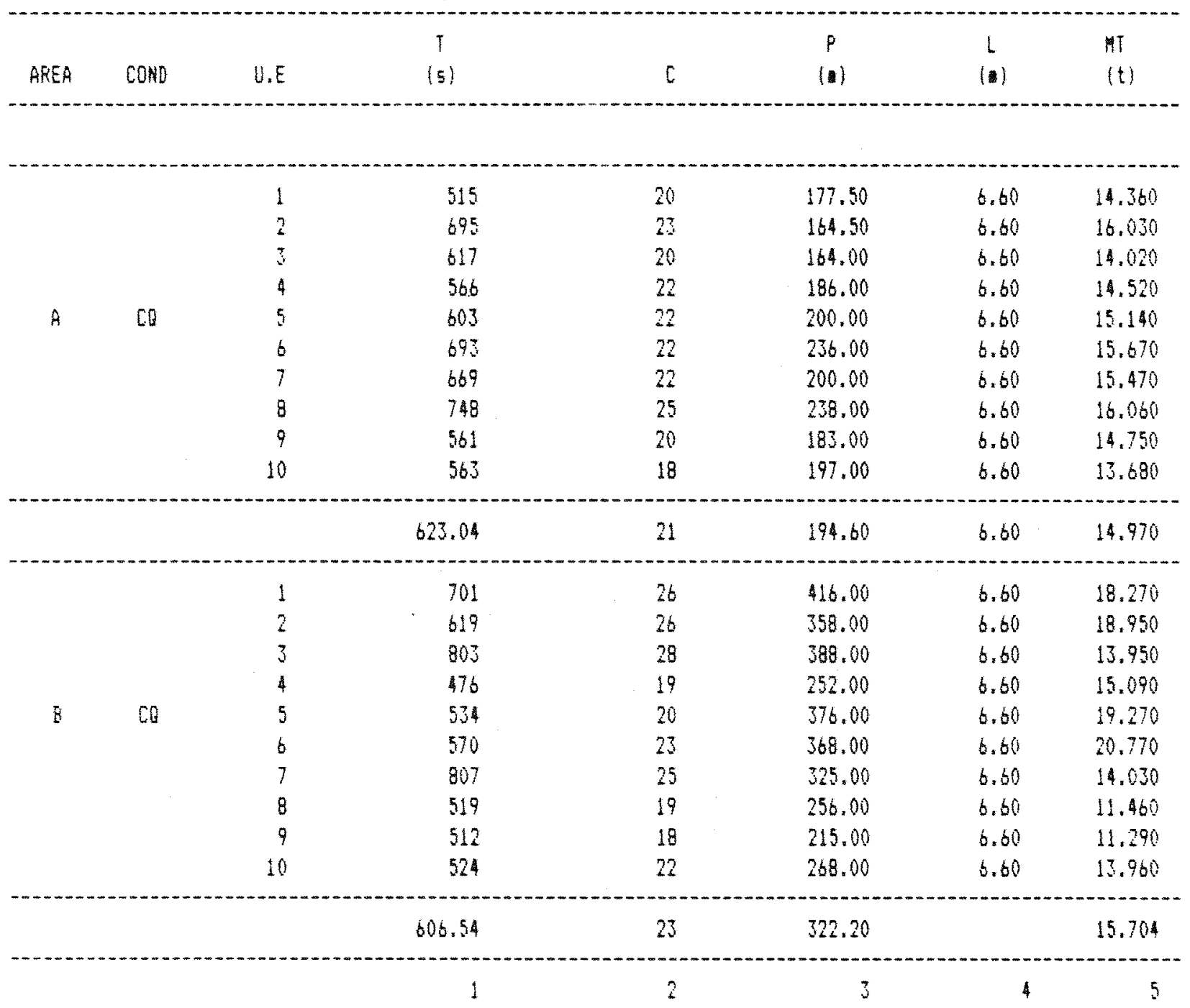




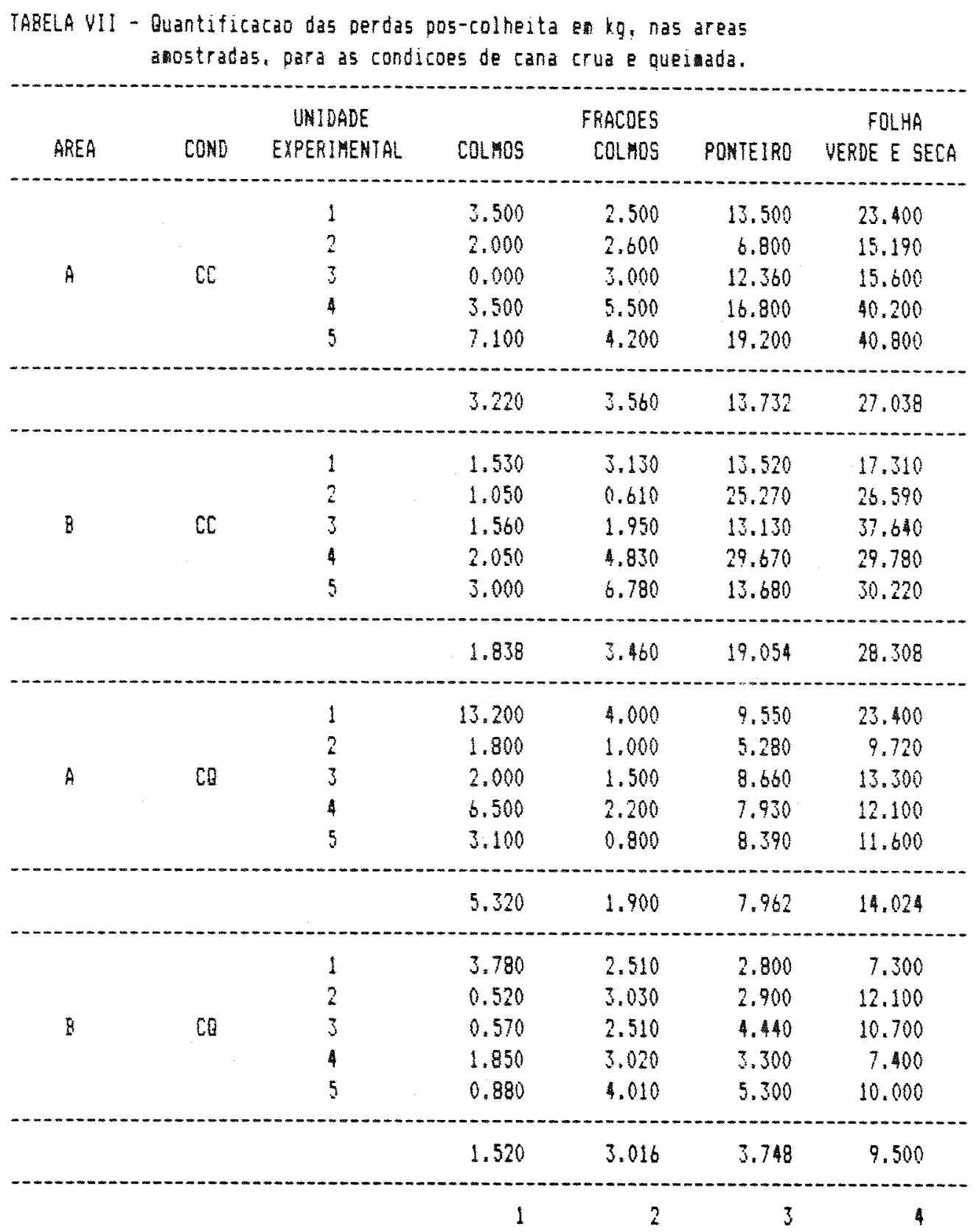


TABELA UIII - Caracterizacao granulonetrica e grau de unidade - U (\%), das fracoes minerais do solo e sua classe textural para as areas experimentais.

\begin{tabular}{|c|c|c|c|}
\hline \multirow[b]{2}{*}{ CANAVIAL } & \multirow[b]{2}{*}{ Acostra } & \multicolumn{2}{|c|}{ AREAS } \\
\hline & & A & $B$ \\
\hline \multirow{5}{*}{ CRUA } & 1 & 30.79 & 12.20 \\
\hline & 2 & 24.25 & 14.15 \\
\hline & 3 & 24.20 & 9.63 \\
\hline & \multirow{3}{*}{$\begin{array}{l}4 \\
5\end{array}$} & 23.42 & 13.52 \\
\hline & & 20.66 & 13.27 \\
\hline & & 24.66 & 12.55 \\
\hline & 1 & 24.70 & 10.42 \\
\hline & 2 & 21.99 & 9.93 \\
\hline \multirow[t]{4}{*}{ QUEIMADA } & 3 & 23.68 & 9.46 \\
\hline & 4 & 29.96 & 12.87 \\
\hline & 5 & 22.24 & 11.78 \\
\hline & & 24.51 & 10.89 \\
\hline & \% ARGILA & 27.85 & 26.40 \\
\hline & : SULIE & 13.73 & 8.67 \\
\hline & \% AREIA & 58.42 & 64.93 \\
\hline
\end{tabular}


TABELA IX - Resultados de assas de: ateria-prina transportada - NT, anostradas pela sonda - MAS, cana Jiapa - MCL, palha - MP, folha verde - MFV, terra - MTR; porcentagens de: aateria estranha vegetal - MEV e aineral MEM, de colos a a ostrados pela sonda - AC; MMY e de colosos industrializaveis transportados MCT, na area experimental A, para a condicao de cana crua.

\begin{tabular}{|c|c|c|c|c|c|c|c|c|c|c|c|}
\hline & 1 & 2 & 3 & $\begin{array}{c}A M \\
4\end{array}$ & $\begin{array}{lll}0 & S & T \\
& & 5\end{array}$ & $\begin{array}{c}R A S \\
\\
\end{array}$ & 7 & $\theta$ & 9 & 10 & gedias \\
\hline 1. MT (t) & 6.700 & 7.860 & 10.180 & 8.610 & 8.810 & 9.510 & 9.660 & 10.660 & 10.430 & 10.690 & 9.311 \\
\hline 2. MAS $(k q)$ & 9.75 & 8.76 & 11.45 & 11.38 & 8.60 & 4.83 & 15.24 & 13.71 & 11.90 & 13.69 & 10.931 \\
\hline 3. $\mathrm{MCL}[\mathrm{kg})$ & 8.80 & 8.90 & 9.40 & 9.60 & 6.80 & 4.10 & 14.00 & 11.00 & 10.00 & 12.00 & 9.260 \\
\hline 4. MP $\{k, Q\}$ & 0.90 & 0.80 & 1.00 & 1.30 & 1.00 & 0.50 & 1.20 & 1.00 & 1.40 & 1.40 & 1.050 \\
\hline 5. MFV $\{\mathrm{kg}\}$ & 0.00 & 1.00 & 1.00 & 0.40 & 0.75 & 0.20 & 0.00 & 1.60 & 0.40 & 0.20 & 0.555 \\
\hline b. MTR $(k g)$ & 0.05 & 0.06 & 0.05 & 0.08 & 0.05 & 0.03 & 0.04 & 0.11 & 0.10 & 0.09 & 0.066 \\
\hline 7. MEV $\left(\begin{array}{l}\% \\
3\end{array}\right)$ & 9.23 & 20.55 & 17.47 & 14.94 & 20.35 & 14.49 & 7.87 & 18.96 & 15.13 & 11.69 & 15.068 \\
\hline 8. MEH $\left(\begin{array}{l}n \\
i\end{array}\right)$ & 0.51 & 0.68 & 0.44 & 0.70 & 0.58 & 0.62 & 0.26 & 0.80 & 0.94 & 0.66 & 0.610 \\
\hline $9 . M(y)$ & 90.26 & 78.77 & 82.10 & 84.36 & 79.07 & 84.89 & 91.86 & 80.23 & 84.03 & 87.66 & 84.322 \\
\hline 10. $\mathrm{MMV}(\mathrm{t})$ & 0.62 & 1.62 & 1.78 & 1.29 & 1.79 & 1.38 & 0.76 & 2.02 & 1.58 & 1.25 & 1.408 \\
\hline 11. & 0.03 & 0.05 & 0.04 & 0.06 & 0.05 & 0.06 & 0.03 & 0.09 & 0.09 & 0.07 & 0.057 \\
\hline 12. MCT (t) & 6.05 & 6.19 & 8.36 & 7.26 & 6.97 & 8.07 & 8.87 & 8.55 & 8.76 & 9.37 & 7.846 \\
\hline
\end{tabular}




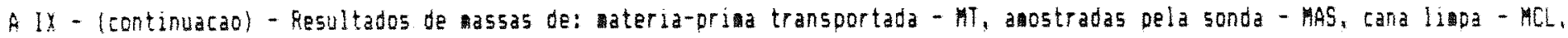
Dalha - MP, folha verde - MFV, terra - MTR; porcentagens de; aterja estranha vegetal - MEV e ineral - MEH, de col wos

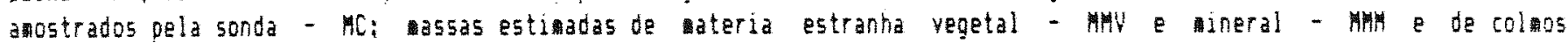
industrializaveis trancoortados MCT, na area experinental B, para a condicao de cana crua.

\begin{tabular}{|c|c|c|c|c|c|c|c|c|c|c|c|}
\hline & 1 & 2 & 3 & ${ }_{4}^{A}$ & $\begin{array}{lll}0 & 5 & 1 \\
& & 5\end{array}$ & $\begin{array}{c}R A 5 \\
6\end{array}$ & 7 & 8 & 9 & 10 & vedias \\
\hline 1. MT $^{T}(t)$ & 10.980 & 8.600 & 9.610 & 9.660 & 9.970 & 10.680 & 10.240 & 8.700 & 10.950 & 12.090 & 10.148 \\
\hline 2. MAS $(k g)$ & 10.78 & 7.22 & 11.33 & 11.24 & 8.48 & 14.14 & 8.47 & 4.41 & 9.72 & 8.01 & 9.380 \\
\hline S. MCL $(\mathrm{kg})$ & 9.00 & 6.00 & 9.80 & 9.60 & 6.40 & 11.00 & 7.20 & 3.80 & 8.20 & 7.00 & 7.800 \\
\hline 4. MF $\{\mathrm{kg}\}$ & 1.20 & 0.80 & 1.40 & 1.20 & 1.20 & 2.20 & 1.00 & 0.60 & 1,00 & 0.80 & 1.140 \\
\hline 5. HFy $(\mathrm{kg})$ & 0.40 & 0.40 & 0.00 & 0.40 & 0.80 & 0.60 & 0.20 & 0.00 & 0.20 & 0.20 & 0.320 \\
\hline 6. MTS $(k g)$ & 0.18 & 0.02 & 0.13 & 0.04 & 0.09 & 0.34 & 0.07 & 0.01 & 0.32 & 0.01 & 0.120 \\
\hline 7. MEU $(B)$ & 14.84 & 16.62 & 12.36 & 14.23 & 23.58 & 19.80 & 14.17 & 13.61 & 12.35 & 12.48 & 15.404 \\
\hline 8. MEH $(t)$ & 1.67 & 0.28 & 1.15 & 0.36 & 0.94 & 2.40 & 0.83 & 0.23 & 3.29 & 0.12 & 1.127 \\
\hline 9. MC $\left(\begin{array}{l}n \\
3\end{array}\right)$ & 83.49 & 83.10 & 86.50 & 95.41 & 75.47 & 77.79 & 85.01 & 86.17 & 84.36 & 87.39 & 83.469 \\
\hline $10 . M m^{2}(t)$ & 1.63 & 1.43 & 1.19 & 1.38 & 2.35 & 2.11 & 1.45 & 1.18 & 1.35 & 1.51 & 1.558 \\
\hline 11. 触 $(t)$ & 0.18 & 0.02 & 0.11 & 0.03 & 0.09 & 0.26 & 0.08 & 0.02 & 0.36 & 0.02 & 0.118 \\
\hline 12. $\operatorname{kct}(t)$ & 9.17 & 7.15 & 8.31 & 8.25 & 7.52 & 8.31 & 8.70 & 7.50 & 9.24 & 10.57 & 8.471 \\
\hline
\end{tabular}




\begin{tabular}{|c|c|c|c|c|c|c|c|c|c|c|c|}
\hline & & & & $A$ & $0 S 1$ & $R A S$ & & & & & \\
\hline & 1 & 2 & 3 & 4 & 5 & 6 & 7 & 8 & 9 & 10 & medias \\
\hline 1. MT (t) & 14,350 & 16.030 & 14.020 & 14.520 & 15.140 & 15.670 & 15.470 & 16.060 & 14.750 & 13,680 & 14.970 \\
\hline 2. MAS $(\mathrm{kg})$ & 10.85 & 15.43 & 13.64 & 16.47 & 12.25 & 12.84 & 13.23 & 6.96 & 10.06 & 12.62 & 12.435 \\
\hline$\therefore, \mathrm{MCL}(\mathrm{kg})$ & 10,00 & 13.60 & 12.00 & 15.00 & 11.80 & 11.40 & 12.20 & 6.00 & 9.80 & 12.20 & 11.400 \\
\hline 4. MP $(k g)$ & 0.80 & 1.80 & 1.60 & 1.00 & 0.40 & 1.40 & 0.40 & 0.40 & 0.20 & 0.40 & 0.840 \\
\hline 5. MFU $(\mathrm{kg})$ & 0,02 & 0.00 & 0.00 & 0.40 & 0,02 & 0.00 & 0.60 & 0.50 & 0.03 & 0.00 & 0.157 \\
\hline b. MTR $(\mathrm{kg})$ & 0.03 & 0.03 & 0.04 & 0.07 & 0.03 & 0.04 & 0.03 & 0.06 & 0.03 & 0.02 & 0.038 \\
\hline 7. MEV $\left(\begin{array}{l}9 \\
h\end{array}\right)$ & 7.56 & 11.67 & 11.73 & 8.50 & 3,43 & 10.90 & 7.56 & 12.93 & 2.29 & 3.17 & 7.973 \\
\hline 8. MEN $\left(\begin{array}{l}4 \\
3\end{array}\right)$ & 0.28 & 0.19 & 0.29 & 0.43 & 0.24 & 0.31 & 0.23 & 0.88 & 0.30 & 0.16 & 0.329 \\
\hline 9. $M C(7)$ & 92.17 & 88.14 & 87.98 & 91.07 & 96.33 & 88.79 & 92.21 & 86.21 & 97.42 & 96.67 & 91.698 \\
\hline 10. MU (t) & 1.09 & 1.87 & 1.64 & 1.23 & 0.52 & 1.71 & 1.17 & 2.08 & 0.34 & 0.43 & 1.200 \\
\hline 11. NMH (t) & 0.04 & 0.03 & 0.04 & 0.06 & 0.04 & 0.05 & 0.04 & 0.14 & 0.04 & 0.02 & 0,050 \\
\hline 12. MCT (t) & 13.24 & 14.13 & 12.33 & 13.22 & 14.58 & 13.91 & 14.27 & 13.84 & 14.37 & 13.22 & 13.712 \\
\hline
\end{tabular}


A X - (continuacao) - Resultados de massas de: nateria-pria transportada - NT, anostradas pela sonda - MAS, cana li palha - MP, folha verde - MFV, terra - MTR; porcentagens de: ateria estranha vegetal - MEV e ineral - MEM, de colaos

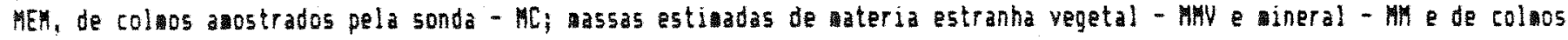
Mh e de colvos industrializaveis - MCi, na area experiaental 8 , para a condicao de cana queiada.

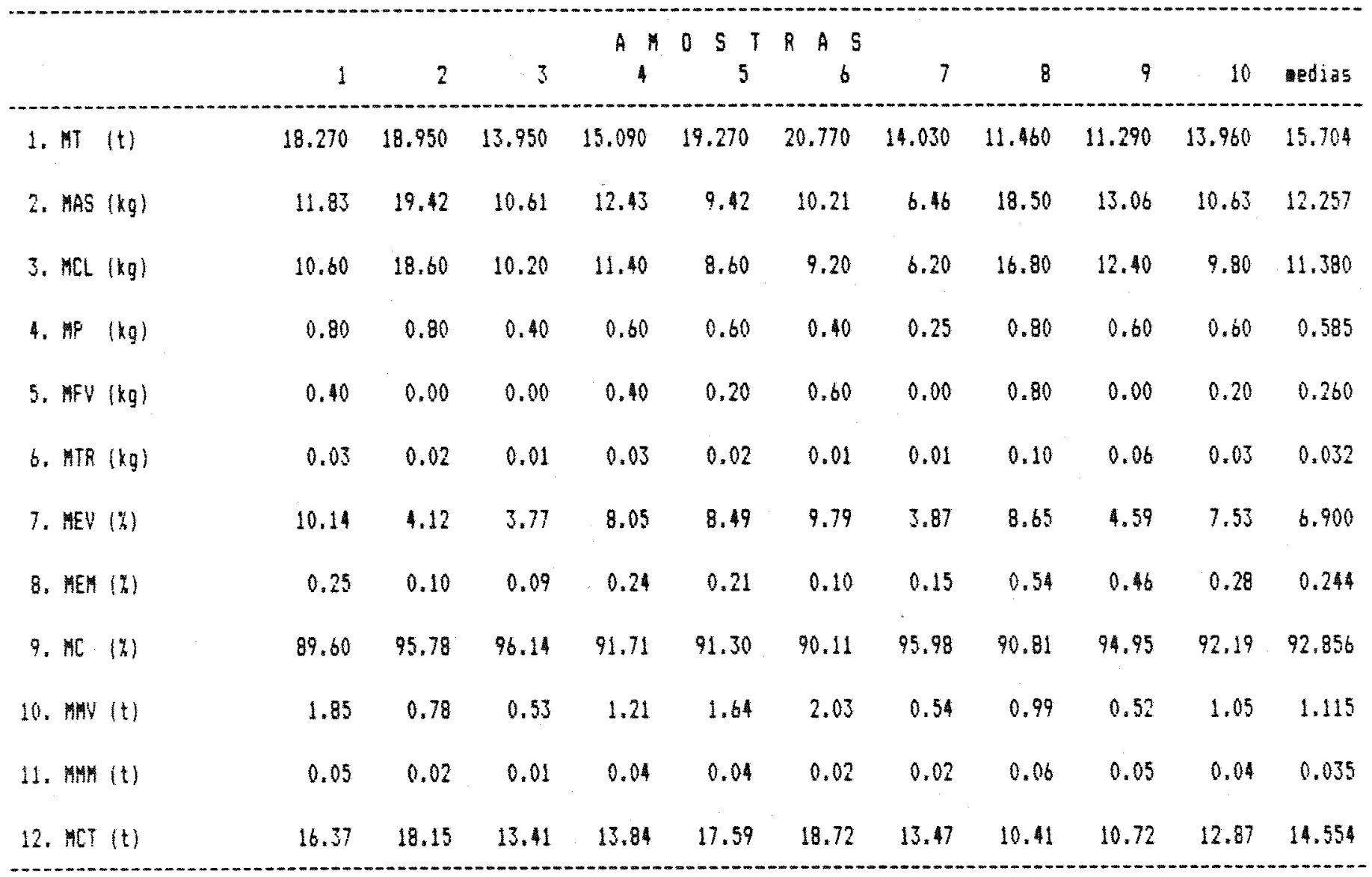


A XI - Resultados da analise tecnologica da materia-pria anostrada

para as areas experiaentais, na condicao de cana crua.

\begin{tabular}{|c|c|c|c|c|c|c|c|c|c|c|c|c|}
\hline \multirow[b]{2}{*}{ iA } & & \multirow[b]{2}{*}{1} & \multirow[b]{2}{*}{2} & \multirow[b]{2}{*}{3} & \multirow[b]{2}{*}{4} & \multirow{2}{*}{ H } & \multirow{2}{*}{5} & \multirow{2}{*}{$\begin{array}{l}R \\
7\end{array}$} & \multirow{2}{*}{$\begin{array}{ll}A & S \\
& \\
& 8\end{array}$} & \multirow[b]{2}{*}{9} & \multirow[b]{2}{*}{10} & \multirow[b]{2}{*}{ medias } \\
\hline & & & & & & & & & & & & \\
\hline 1 & PESO CARGA $(t)$ & 6.700 & 7.860 & 10.180 & 8.610 & 8.810 & 9.510 & 9.660 & 10.660 & 10.430 & 10.690 & 9.311 \\
\hline & \multicolumn{12}{|l|}{ REFRATOMETRO: } \\
\hline & FATOR & 1 & 1 & 1 & 1 & 1 & 1 & 1 & 1 & 1 & 1 & \\
\hline & BRIX & 20.80 & 19.70 & 18.80 & 20.10 & 20.10 & 19.60 & 18.40 & 18.40 & 19.60 & 18.50 & 19.40 \\
\hline & AEIO & 19.96 & 32.70 & 9.82 & 18.89 & 15.81 & 21.25 & 0.98 & -0.92 & 9.85 & 10.29 & 13.86 \\
\hline & \multicolumn{12}{|l|}{ SACARIMETRO: } \\
\hline & L.COR & 74.88 & 74,22 & 67.39 & 72.65 & 73.22 & 70.78 & 64.17 & 64.71 & 69.12 & 65.56 & 69.67 \\
\hline & DENSIDADE & 1.08347 & 1.07858 & 1.07461 & 1.08035 & 1.08035 & 1.07814 & 1.07285 & 1.07285 & 1.07814 & 1.07329 & 1.07726 \\
\hline & POL : & 17.97 & 17.89 & 16.30 & 17.48 & 17.62 & 17.07 & 15.55 & 15.68 & 16.67 & 15,88 & 16.81 \\
\hline & PCC & 14.3039 & 15,1728 & 13.056 & 14.0937 & 13.6365 & 14.3601 & 12.2914 & 11.9636 & 13.2927 & 13.2261 & 13.53997 \\
\hline & PUREIA & 86.39 & 90.81 & 86.70 & 86.96 & 87.66 & 87.09 & 84.51 & 85,21 & 85.05 & 85.83 & 86,62 \\
\hline & PESO DO BOLO (9) & 157.0 & 133.5 & 154.7 & 152.2 & 167.2 & 136.4 & 159.7 & 172.6 & 156.6 & 140.4 & 153.0 \\
\hline & FIBRA : CANA & 15.50 & 11.93 & 15.15 & 14.77 & 17.05 & 12.37 & 15.91 & 17.87 & 15.44 & 12.97 & 14,90 \\
\hline & BAGACO Ч СAAA & 34.31 & 26.41 & 33.53 & 32.69 & 37.74 & 27.38 & 35.21 & 39.55 & 34.17 & 28.71 & 32.97 \\
\hline & EXT:POL & 94,63 & 96.10 & 94.25 & 94.80 & 93.80 & 95.73 & 93.58 & 92.59 & 94.24 & 95.14 & 94.49 \\
\hline
\end{tabular}


A XI - (continuacao) - Resultados da analise tecnologica da ateria-pri a actrada para as areas experimentais, na condicao de cana crua.

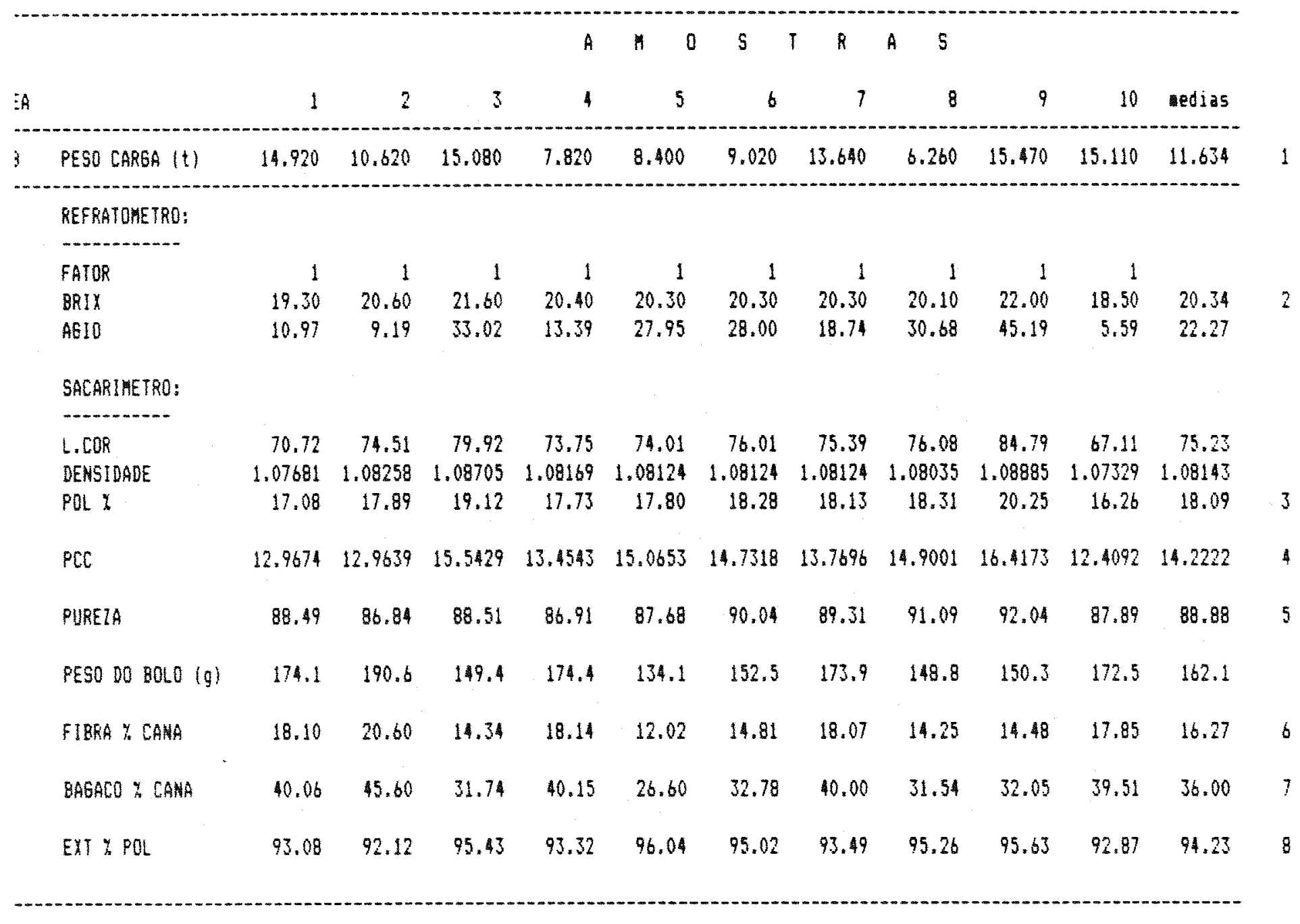


A xII - Resultados da analise tecnologica da ateria-priea amostrada para as areas experimentais na condicao de cana queinada.

\begin{tabular}{|c|c|c|c|c|c|c|c|c|c|c|c|}
\hline & & & & $A$ & $H$ & $s$ & $R$ & A & & & \\
\hline A & 1 & 2 & 3 & 4 & 5 & 6 & 7 & 8 & 9 & 10 & medias \\
\hline PESO CARGA ( $t$ ) & 14.360 & 16.030 & 14.020 & 14.520 & 15.140 & 15.670 & 15.470 & 16.060 & 14.750 & 13.680 & 14.970 \\
\hline \multicolumn{12}{|l|}{ REFRATOMETRO: } \\
\hline FATOR & 1 & 1 & 1 & 1 & 1 & 1 & 1 & 1 & 1 & 1 & \\
\hline BRI & 19.00 & 20.20 & 18.50 & 20.50 & 17.80 & 17.40 & 18.20 & 19.10 & 18.50 & 18.20 & 18.74 \\
\hline AGIO & 12.03 & 26.79 & 14.00 & 23.92 & 1.14 & 3.35 & 12.51 & 23.79 & 20.02 & 1.59 & 13.91 \\
\hline \multicolumn{12}{|l|}{ SACARIMETRO: } \\
\hline L.COR & 68.97 & 72.17 & 65.17 & 75.18 & 60.80 & 59.85 & 64.29 & 69.12 & 69.02 & 60.30 & 66.52 \\
\hline DEMSIDADE & 1.07549 & 1.0808 & 1.07329 & 1.08213 & 1.07022 & 1.06848 & 1.07197 & 1.07593 & 1.07329 & 1.07197 & 1.07436 \\
\hline POL $\%$ & 16.67 & 17.36 & 15.79 & 18.06 & 14.77 & 14.56 & 15.59 & 16.78 & 16.72 & 14.63 & 16.09 \\
\hline PCC & 13.1908 & 15.192 & 13.7532 & 14.5357 & 12.5224 & 12.6932 & 13.5208 & 14.548 & 13.7751 & 12.9846 & 13.6716 \\
\hline PUREZA & 87.73 & 85.94 & 85.35 & 88.09 & 82.97 & 83.67 & 85.85 & 87.85 & 90,37 & 80.38 & 85.82 \\
\hline PESO DO BOLO $(g)$ & 159.1 & 121.2 & 123.4 & 153.2 & 133.7 & 122.9 & 124.7 & 124.9 & 144.2 & 115.9 & 132.3 \\
\hline FIBRA I CANA & 15.82 & 10.06 & 10.39 & 14.92 & 11.96 & 10.31 & 10.59 & 10.62 & 13.55 & 9.25 & 11.75 \\
\hline BAGACO : CANA & 35.02 & 22.27 & 33.02 & 26.47 & 22.82 & 23.44 & 23.51 & 29.99 & 20.97 & 39.51 & 27.65 \\
\hline EXT : $\mathrm{POL}$ & 94.05 & 96.72 & 94.62 & 95.92 & 95.92 & 95.86 & 96.11 & 95.38 & 96.67 & 93.18 & 95.44 \\
\hline
\end{tabular}


A XII - (continuacao) - Resultados da analise tecnologica da abteria-prina anostrada

\begin{tabular}{|c|c|c|c|c|c|c|c|c|c|c|c|}
\hline \multirow[b]{2}{*}{$A$} & \multirow[b]{2}{*}{1} & \multirow[b]{2}{*}{2} & \multirow[b]{2}{*}{3} & \multirow{2}{*}{$\begin{array}{l}A \\
4\end{array}$} & \multirow{2}{*}{$M$} & \multirow{2}{*}{$\begin{array}{l}5 \\
6\end{array}$} & \multirow{2}{*}{$\begin{array}{l}T \quad R \\
\\
\\
\end{array}$} & \multirow{2}{*}{$\begin{array}{ll}A & S \\
& 8\end{array}$} & \multirow[b]{2}{*}{9} & \multirow[b]{2}{*}{10} & \multirow[b]{2}{*}{ Medias } \\
\hline & & & & & & & & & & & \\
\hline PESO CARGA $(t)$ & 18.270 & 18.950 & 13.950 & 15.090 & 19.270 & 20.770 & 14.030 & 11.460 & 11.290 & 13.960 & 15.704 \\
\hline \multicolumn{12}{|l|}{ REFRATOMETRO: } \\
\hline Fator & 1 & 1 & 1 & 1 & 1 & 1 & & 1 & 1 & 4 & \\
\hline Briva & 20.30 & 20.60 & 18.90 & 18.80 & 19.10 & 19.60 & 19.70 & 21.00 & 20.00 & 19.90 & 19.79 \\
\hline A610 & 24.89 & 38.81 & 22.61 & 18.01 & 21.47 & 22.29 & 27.97 & 26.59 & 28.67 & 27.30 & 25.86 \\
\hline \multicolumn{12}{|l|}{ SACARIMETRO: } \\
\hline L.COR & 73.77 & 76.36 & 68.39 & 67.81 & 68.10 & 69.65 & 72.90 & 77.72 & 73.35 & 71.43 & 71.95 \\
\hline DENSIDADE ' & 1.08124 & 1.08258 & 1.07505 & 1.07461 & 1.07593 & 1.07814 & 1.07858 & 1.08436 & 1.07991 & 1.07947 & 1.07899 \\
\hline POL : & 17.74 & 18.34 & 16.54 & 16.41 & 16.46 & 16.90 & 17.57 & 18.64 & 17.66 & 17.20 & 17.34 \\
\hline PCE & 14.7462 & 16.1273 & 14.4648 & 14.0433 & 14.5259 & 14.6954 & 14.8538 & 14.7497 & 15.0633 & 15.179 & 14.8449 \\
\hline PUREIA & 87.38 & 89.02 & 87.51 & 87.28 & 86.17 & 85.71 & 89.18 & 88.76 & 88.30 & 86.43 & 87.57 \\
\hline PESO DO $80 L 0(g)$ & 140.9 & 119.6 & 121.6 & 130.1 & 118.1 & 121.5 & 134.8 & 159.1 & 131.4 & 118.1 & 129.5 \\
\hline FIBRA : CANA & 13.05 & 9.81 & 10.12 & 11.41 & 9.58 & 10.1 & 12.12 & 15.82 & 11.61 & 9.58 & 11.32 \\
\hline BAGACO $\%$ CANA & 28.88 & 21.71 & 22.40 & 25.25 & 21.20 & 22.36 & 26.83 & 35.02 & 25.70 & 21.20 & 25.06 \\
\hline EXT:POL & 95.61 & 96.98 & 96.53 & 95.97 & 96.73 & 96.59 & 95.95 & 94.68 & 96.18 & 96.87 & 96.21 \\
\hline
\end{tabular}


TABELA XIII - Resultado das deterinacoes do orau de unidade - U (1) co base el peso undo dos componentes vegetais da eateria-prina para as condicoes de cana crua e queineda nas argas experinentais.

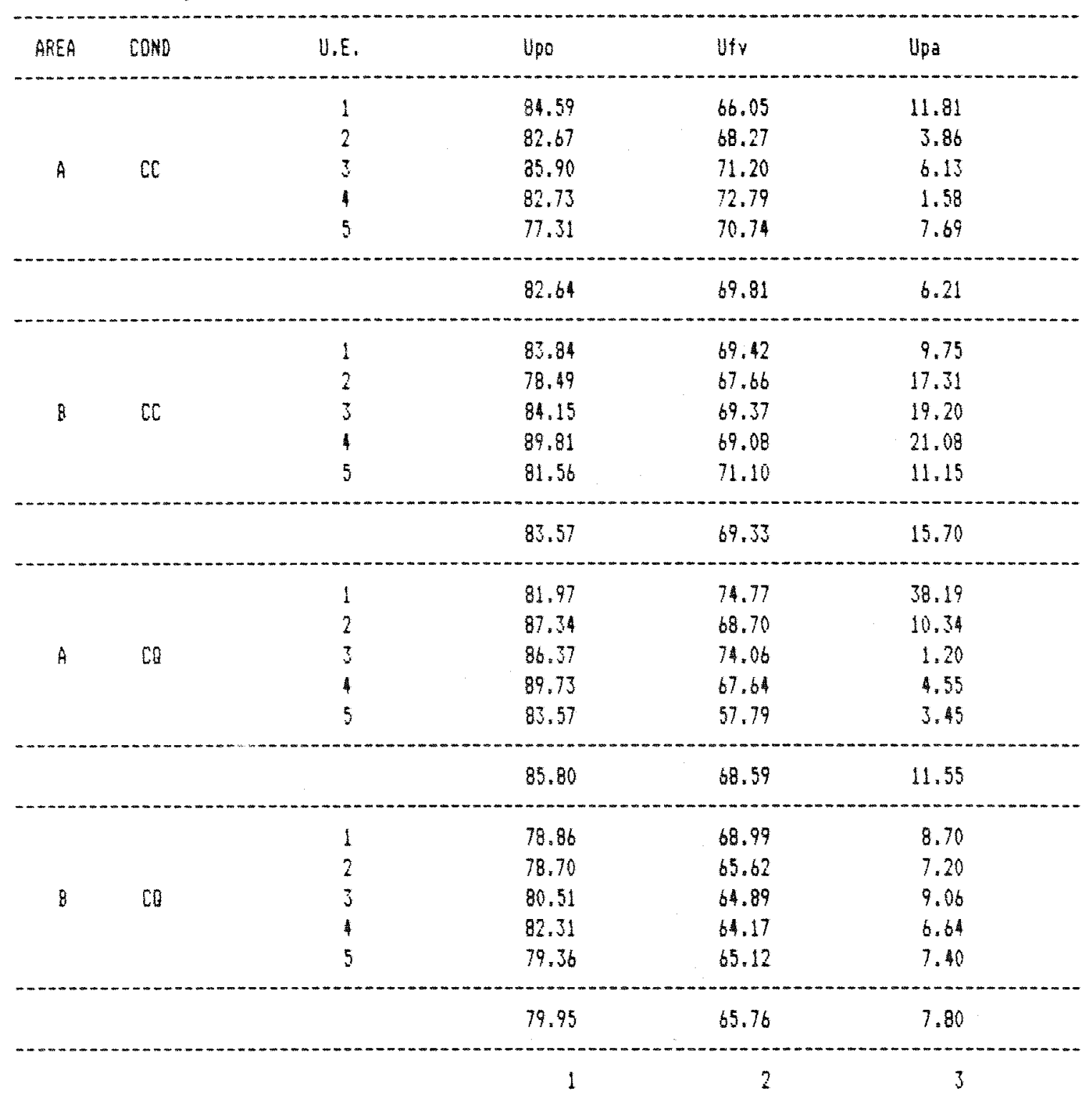


TABELA XIV - Resultados das deterainacoes de poder calorifico superior PCS (kcal/kg), dos componentes vegetais da ateria-prios para cana crua equeinada nas areas experiaentais.

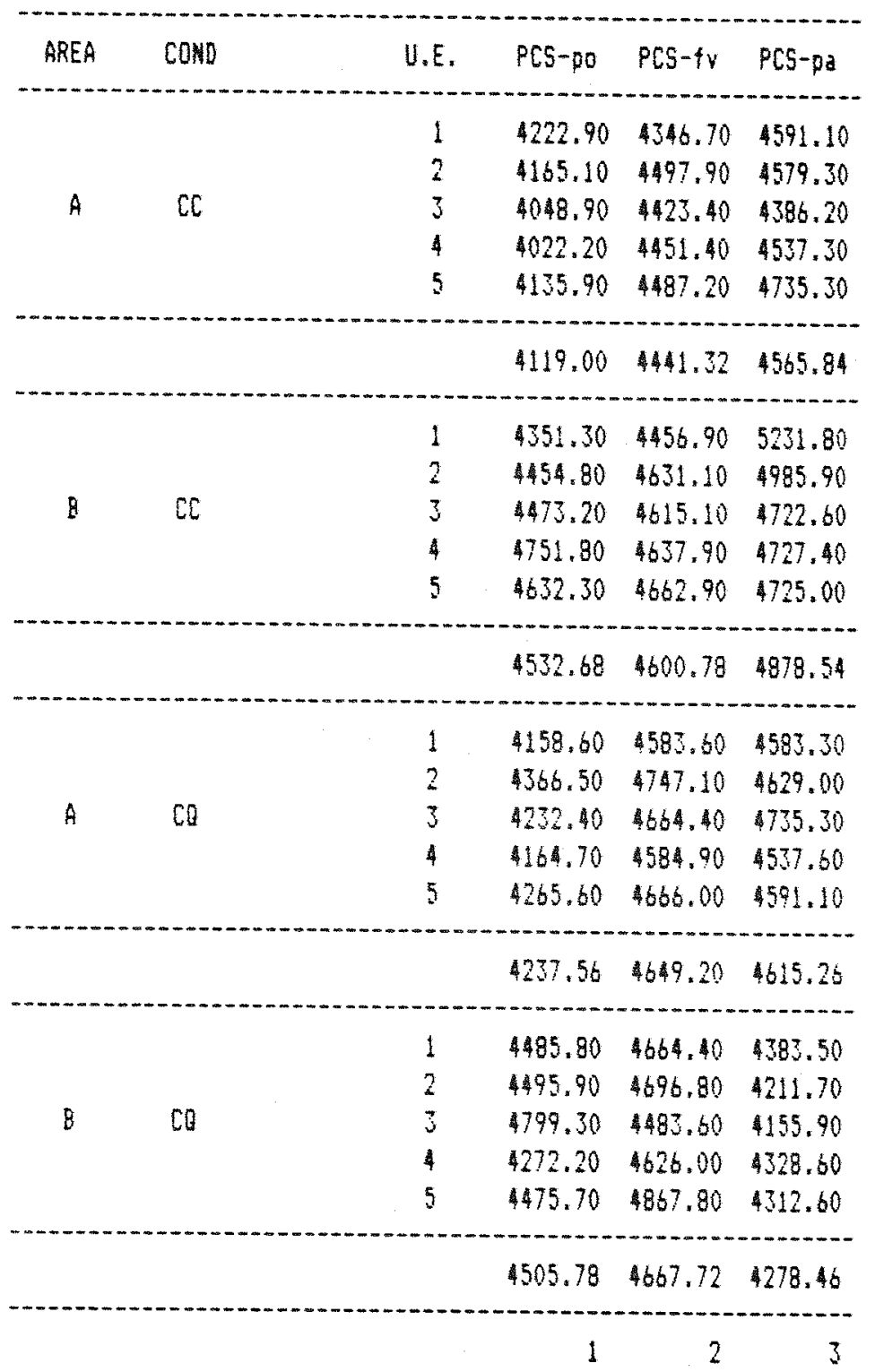


TABELA XV - Valores médios do preço oficial da tonelada de cana-de-açúcar, bagaço "in natura" e palhiço(*) para o mês de julho de 1992, convertidos em US\$.(Cooperativa dos Plantadores de Cana do Estado de São Paulo Informação Pessoal, 1992).

\begin{tabular}{ccc}
\hline CANA-DE-AÇÚCAR & BAGAÇO & PALHIÇO \\
\hline (US $\$ /$ t) & (US\$/t) & (US\$/t) \\
\hline 9,73 & 7,78 & 5,14 \\
\hline
\end{tabular}

Dólar julho/92 $=$ Cr $\$ 4.204,60$

(*) MOLINA JUNIOR, 1991

TABELA XVI - Valores médios dos custos operacionais de corte,referentes ao mês de julho de 1992, convertidos em US\$. (Usina Costa Pinto - Informação Pessoal, 1992).

\begin{tabular}{ccc}
\hline Corte Manual & Cana Crua & 0,86 \\
\hline Corte Manual & Cana Queimada & 0,74 \\
\hline
\end{tabular}

Dólar julho/92 $=$ Cr\$ 4.204,60 
TABELA XVII - Valores médios dos custos operacionais de carregamento e transporte para cana-de-açúcar e palhiço, referentes ao mês de julho de 1992, convertidos em US\$. (Usina Costa Pinto - Informação Pessoal, 1992).

\begin{tabular}{lllll}
\hline \multicolumn{1}{c}{ OPERAÇÕES } & EQUIPAMENTOS & US $\$ \mathrm{~h}$ & US $\$ \mathrm{~km}$ & US $\$ \mathrm{t}$ \\
\hline Carregamento & Trator Valmet & & & \\
& 118.4 & & & \\
& Carregadora & 33,12 & & \\
& Motocana & & & \\
\hline Transporte & MB 2219 & & \\
& $9,50 \mathrm{~km}$ & 1,16 & \\
& $14,00 \mathrm{~km}$ & 1,57 & \\
\hline
\end{tabular}

Carreg/Transp.

de Palhiço

$3,55^{*}$

Dólar julho/92 $=\mathrm{Cr} \$ 4.204,60$

(*) RIPOLI, 1991

TABELA XVIII - Valores m/edios dos custos operacionais de lavagem da cana-de-açúcar na indústria e catą̧ão da bituca pós-colheita, referentes ao mês de juho de 1992, convertidos em US\$. (Cooperativa dos Produtores de Açúcar e Álcool - COPERSUCAR - Informação Pessoal, 1992).

\begin{tabular}{lc}
\hline OPERAÇÕES & US $\$ / t$ \\
\hline Lavagem da cana-de-açúcar & 0,21 \\
\hline Catação da bituca & 0,08 \\
\hline
\end{tabular}

Dólar julho/92 = Cr\$4.204,60 


\section{APÊNDICE 2}

\section{DADOS TRANSFORMADOS}

Os dados apresentados nas Tabelas deste Apêndice referem-se áqueles obtidos através de transformações realizadas a partir dos dados originais que se encontram no Apêndice 1. 


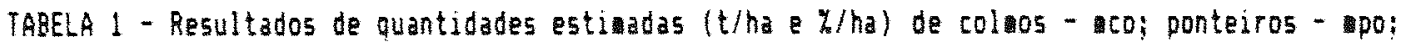
folhas verdes - fv; palhas - pa; palhico - e indice de palhico - ip para as condicoes de cana crua e quei iada nas areas experi ientais.

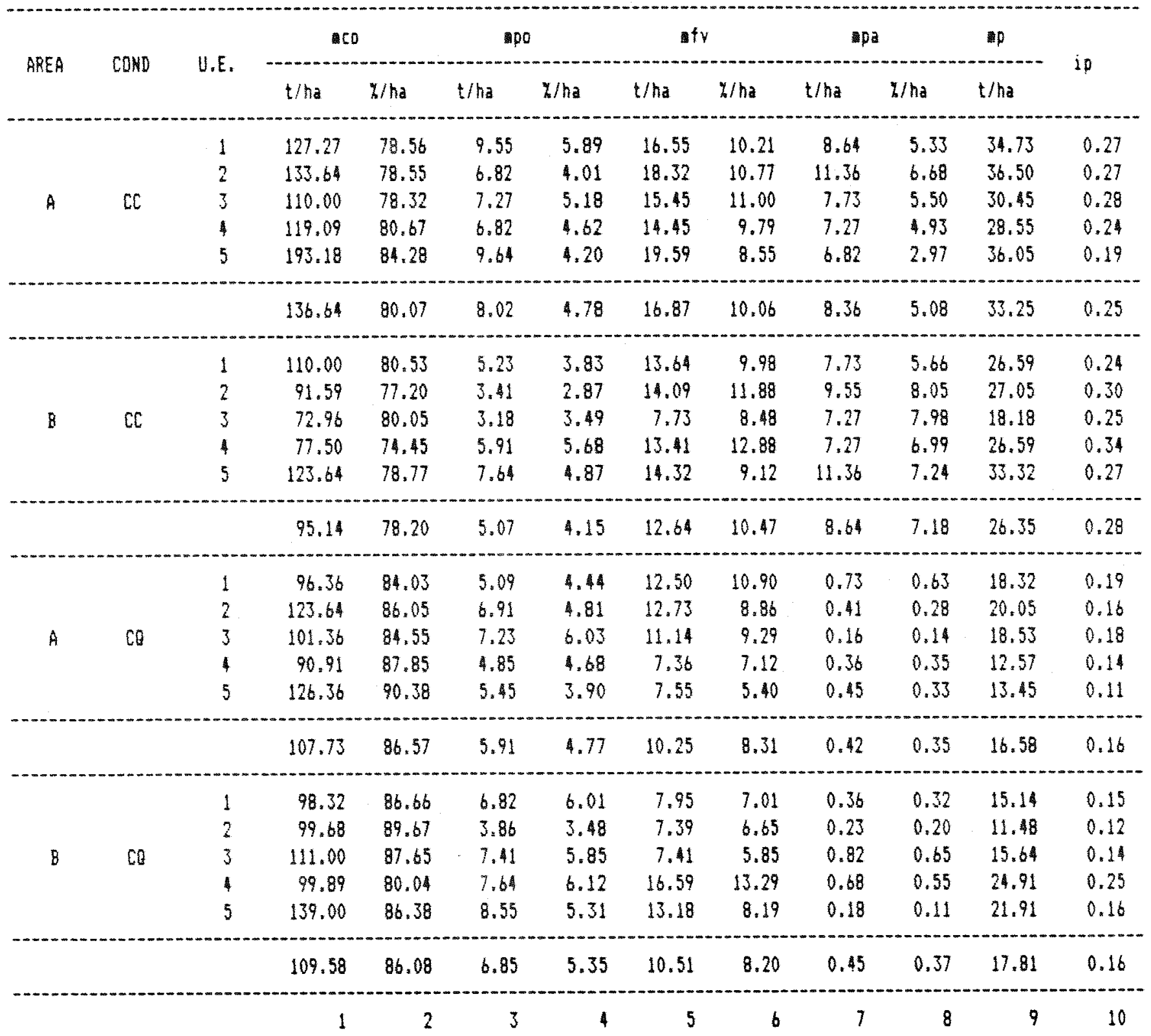


TABELA 2 - Deseapento operacional do corte manual, valores medios obtidos pela inetrage diaria cortada para tres periodos nas condicoes de cana crua e queinada nas areas experimentais.

\begin{tabular}{|c|c|c|c|c|c|c|c|}
\hline AREA & COMD & $\begin{array}{c}\text { PRoDUTIV. } \\
\text { (t/ha) }\end{array}$ & 1 & 2 & 3 & $\begin{array}{l}\text { TOTAL DIARIO } \\
\text { metros/home }\end{array}$ & $\begin{array}{l}\text { D.OPERACIONAL } \\
\text { (t/homea dia) }\end{array}$ \\
\hline \multirow[t]{2}{*}{ A } & $C C$ & 136.64 & 13.79 & 13.35 & 13.61 & 40.75 & 3.67 \\
\hline & $C O$ & 107.73 & 30.54 & 28.28 & 25.53 & 84.35 & 6.90 \\
\hline \multirow[t]{2}{*}{8} & $C C$ & 95.09 & 13.93 & 18.38 & 13.97 & 46.28 & 2.90 \\
\hline & $\mathrm{CO}$ & 109.58 & 58.79 & 56.57 & 31.15 & 146.51 & 10.59 \\
\hline
\end{tabular}


TABELA : - Desenpenho operacional do carregaento da ateria-prima: Deterinacoes da area trabalhada - Ac (12); Capacidade Operacional - Coc (ha/h) \& COC (t/h) da ateria-pria recolhida nas areas experimentais para a condicao de cana crua.

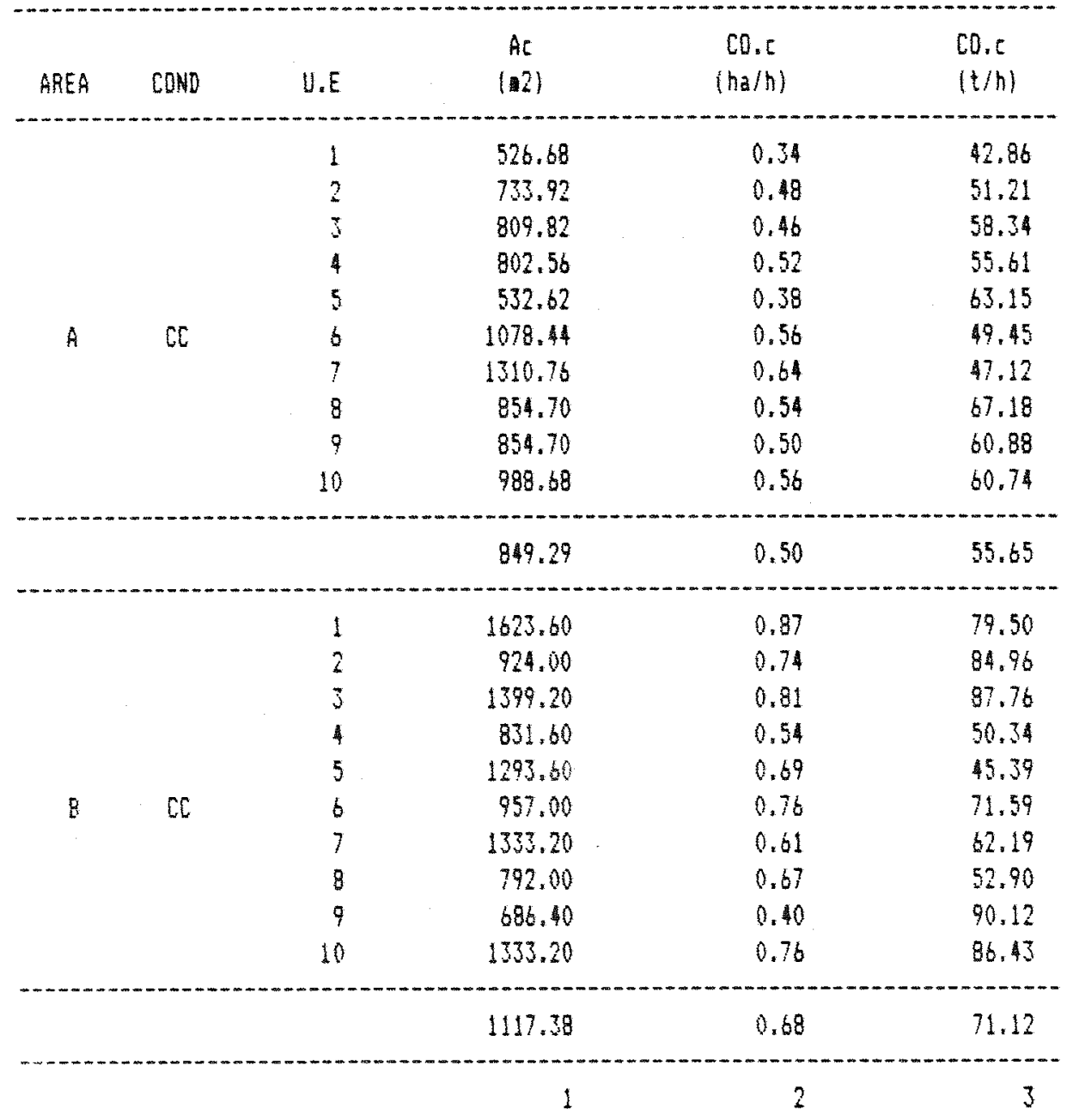


TABELA 3 - (continuacao) Deseapenho operacional do carreqachento da ateria-prima: Deter inacoes da area tpabalhada - Ac (2); Capacidade Operacional COc (ha/h) e coc $(t / h)$ da ateria-priala recolhida nas areas experimentais para a condicao de cana queiada.

\begin{tabular}{|c|c|c|c|c|c|}
\hline AREA & COND & U.E & $\begin{array}{c}A C \\
(2)\end{array}$ & $\begin{array}{c}C 0 . c \\
(h a / h)\end{array}$ & $\begin{array}{l}C 0 . c \\
(t / h)\end{array}$ \\
\hline \multirow{10}{*}{ A } & \multirow{10}{*}{$\mathrm{CQ}$} & 1 & 1171.50 & 0.82 & 100.42 \\
\hline & & 2 & 1085.70 & 0.56 & 82.99 \\
\hline & & 3 & 1082.40 & 0.63 & 81.75 \\
\hline & & 4 & 1227.60 & 0.78 & 92.39 \\
\hline & & 5 & 1320.00 & 0.79 & 90.39 \\
\hline & & $b$ & 1557.60 & 0.81 & 81.40 \\
\hline & & 7 & 1320.00 & 0.71 & 83.25 \\
\hline & & 8 & 1570.80 & 0.76 & 77.27 \\
\hline & & 9 & 1207.80 & 0.78 & 94.65 \\
\hline & & 10 & 1300.20 & 0.83 & 97.51 \\
\hline$-\cdots-m-m$ & \multirow{11}{*}{$\mathrm{CQ}$} & & 1284.36 & 0.75 & 87.20 \\
\hline \multirow{10}{*}{8} & & 1 & 2745.60 & 1.41 & 93.77 \\
\hline & & 2 & 2362.80 & 1.38 & 110.28 \\
\hline & & 3 & 2560.80 & 1.15 & 62.56 \\
\hline & & 4 & 1663.20 & 1.26 & 114.03 \\
\hline & & 5 & 2481.60 & 1.67 & 129.91 \\
\hline & & 6 & 2129.90 & 1.53 & 131.18 \\
\hline & & 7 & 2145.00 & 0.96 & 62.59 \\
\hline & & 8 & 1689.60 & 1.17 & 79.49 \\
\hline & & 9 & 1419.00 & 1.00 & 79.32 \\
\hline & & 10 & 1768.80 & 1.22 & 95.95 \\
\hline \multirow{2}{*}{ 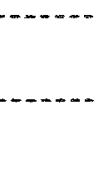 } & & & 2126.52 & 1.27 & 95.91 \\
\hline & & & 1 & 2 & 3 \\
\hline
\end{tabular}




\begin{tabular}{|c|c|c|c|c|}
\hline \multirow[b]{2}{*}{ AREA } & \multicolumn{4}{|c|}{$\begin{array}{l}\text { Distancia - D (n) Carqu Transportada - MT (t) } \\
\text { Dara as condicoes de cana crua e queinada ras } \\
\text { areas experinentais. }\end{array}$} \\
\hline & COND & $\begin{array}{l}\text { CAREA } \\
\text { TRANSPORTADA } \\
\text { (t) }\end{array}$ & $\begin{array}{l}\text { DISTANCIA DE } \\
\text { TRANSFOHTE } \\
\text { (ka) }\end{array}$ & $\begin{array}{l}\text { CAEACIDADE } \\
\text { OPESACIONAL } \\
\text { (t,k) }\end{array}$ \\
\hline \multirow{2}{*}{$A$} & $\omega$ & 9.311 & 9.5 & 88.45 \\
\hline & 00 & 14.970 & 9.5 & 142.22 \\
\hline \multirow{2}{*}{8} & $c c$ & 11.642 & 14.0 & 162.96 \\
\hline & $\mathrm{CO}$ & 15.704 & 14.0 & 219.86 \\
\hline
\end{tabular}


TAGELA - Guantificacao das derdas pos-colheita en tha, nas areas experinentais A E b. para as condicoes de cana crua e queinada.

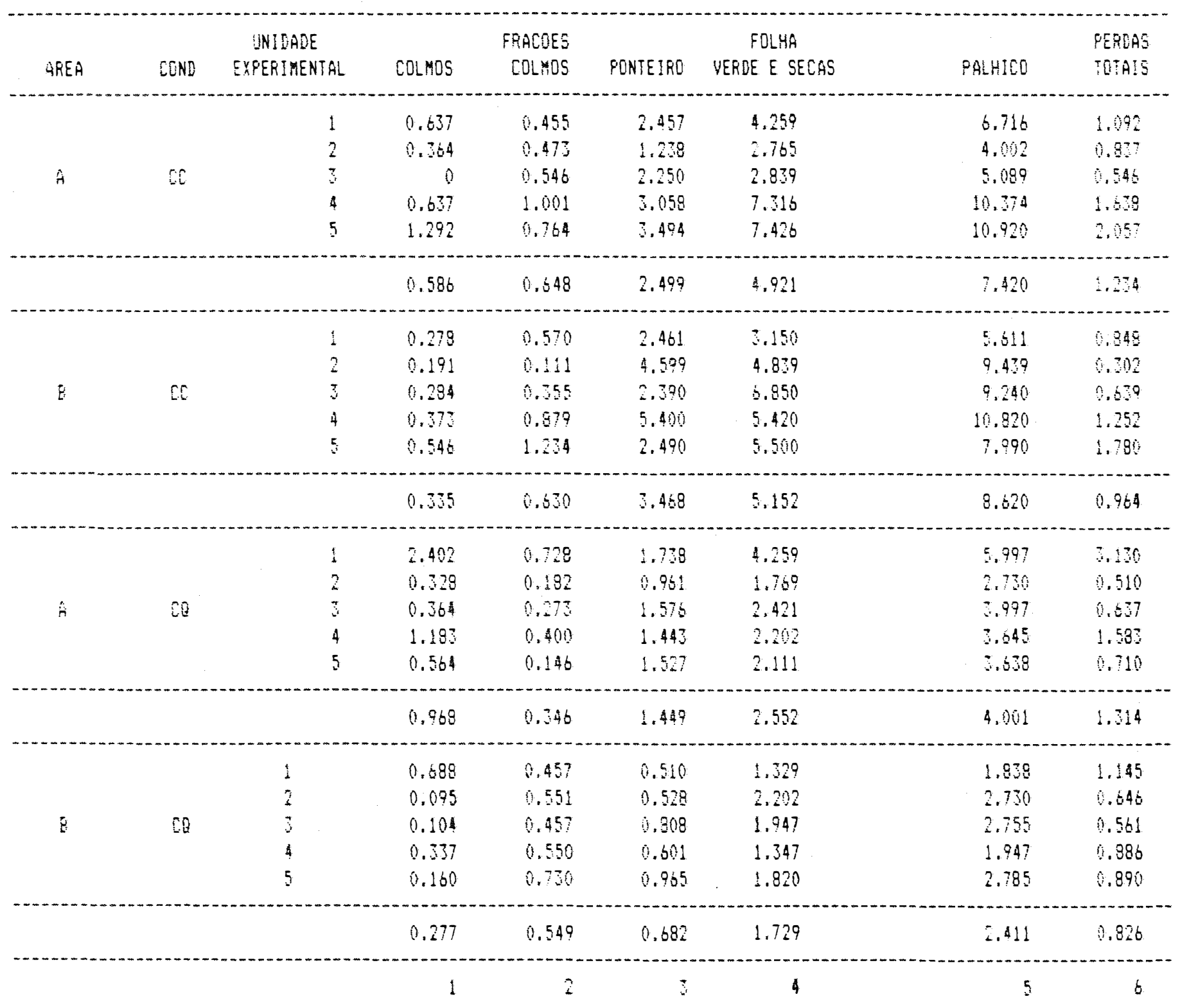


TAEELA o - Resultados das deterninacoes dos poderes caloriflzos inierior - pCi a util - PCU en (keal/lg) das partes componentes do palhaco loonteiros

- Fo, folhas verdes - FV e paltias - PA\}, para as areas evoeriantais nas condicoes de cana cruze quelaja.

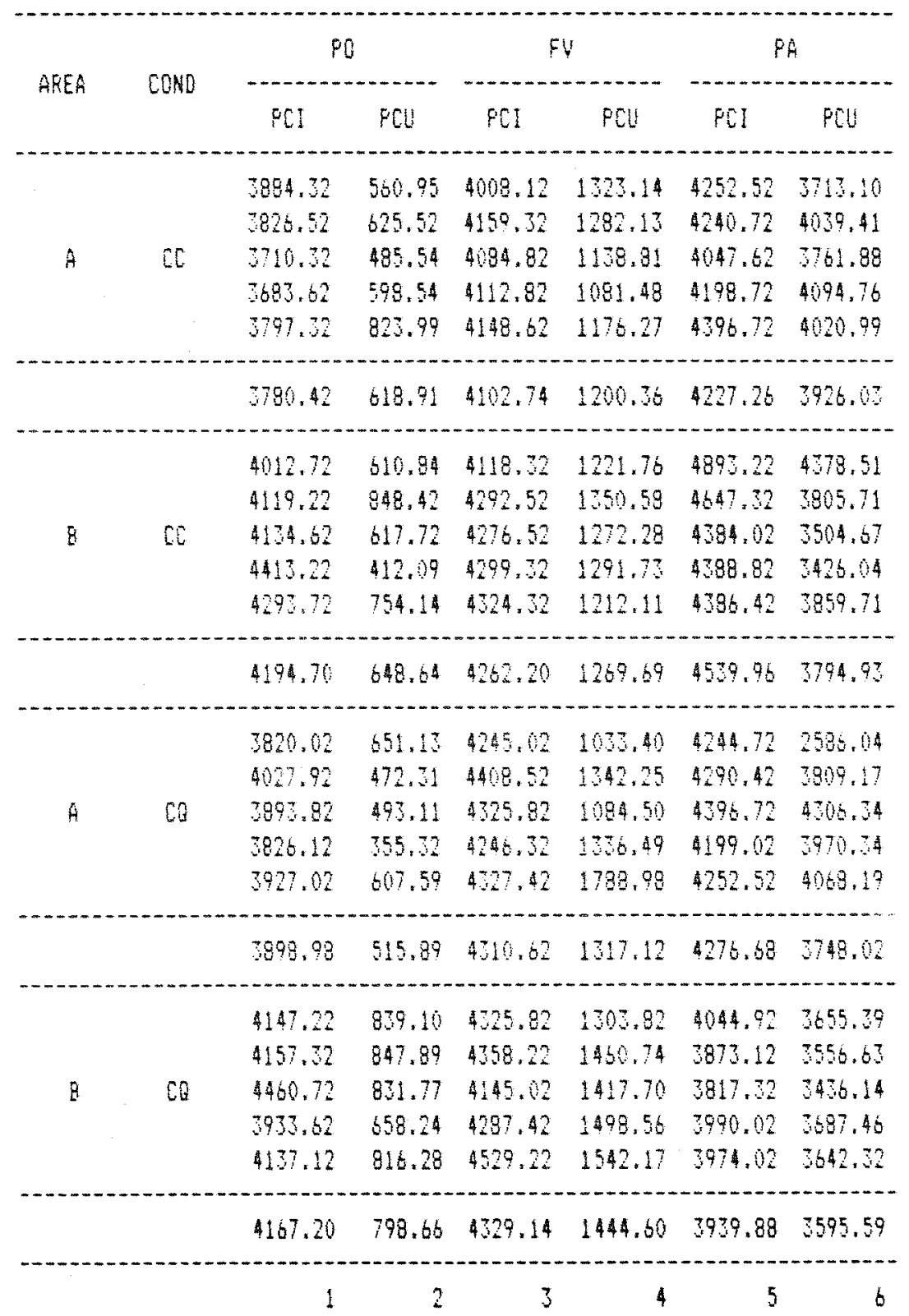




\section{APÊNDICE 3}

\section{MEMÓRIA DE CÁLCULO}

São apresentadas, a seguir, as memórias de cálculo das Tabelas integrantes do trabalho, determinadas a partir dos dados originais constantes no Apêndice 2.

Os números e letras entre parênteses referem-se às colunas, enquanto que, quando seguidas por letras $\mathrm{T}$, indicam suas Tabelas de origem.

Letras $T$ seguidas de algarismos romanos referem-se as Tabelas do Apêndice 1, e as seguidas de algarismos arábicos referem-se as Tabelas do Apêndice 2. Números de colunas sem acompanhamento de letras $T$ referem-se as colunas da própria Tabela. Os números sem estarem entre parênteses, dizem respeito a valores de conversão de unidade ou constantes. SUM = somatórias e MED = médias. 
TABELA 1: $\quad(1)=(5) \mathrm{T}_{1} \times 9,091$

$(2)=[(1) /(1)+(9)] \times 100$

(3) $=(6) T_{1} \times 9,091$

(4) $=[(3) /(1)+(9)] \times 100$

(5) $=(7) \mathrm{T}_{1} \times 9,091$

$(6)=[(5) /(1)+(9)] \times 100$

$(7)=(8) \mathrm{T}_{1} \quad \times 9,091$

$(8)=[(7) /(1)+(9)] \times 100$

$(9)=\operatorname{SUM}(3)+(5)+(7)$

$(10)=(9) /(1)$

TABELA 2: $\quad(2)=(1) \mathrm{T}_{\mathrm{II}}$ a $\mathrm{T}_{\mathrm{V}}$

$(3)=(2) \mathrm{T}_{\mathrm{II}} \mathrm{a} \cdot \mathrm{T}_{\mathrm{V}}$

(4) $=(3) T_{I I}$ a $T_{V}$

$(5)=(4) T_{\mathrm{II}} a T_{\mathrm{V}}$

$(6)=[(1) / 9091] \times(5) \times 6$

TABELA 3: $\quad(1)=(3) \mathrm{T}_{\mathrm{V}]} \times(4) \mathrm{T}_{\mathrm{V} 1}$

(2) $=[(1) \times 0,36] /(1) \mathrm{T}_{\mathrm{VI}}$

(3) $=(5) \mathrm{T}_{\mathrm{VI}} \times 3600 /(1) \mathrm{T}_{\mathrm{VI}}$

TABELA 4: $\quad(1)=(5) \mathrm{T}_{\mathrm{VI}}$

$$
(2)=(5) T_{\mathrm{VI}} \times(3)
$$


TABELA 5: $\quad(1)=(1) \mathrm{T}_{\mathrm{VIJ}} \times 0,182$

$(2)=(2) \mathrm{T}_{\mathrm{VII}} \times 0,182$

(3) $=(3) \mathrm{T}_{\mathrm{VII}} \times 0,182$

(4) $=(4) \mathrm{T}_{\mathrm{VII}} \times 0,182$

(5) $=(3) \mathrm{T}_{\mathrm{VII}}+(4) \mathrm{T}_{\mathrm{VII}}$

(6) $=(1) \mathrm{T}_{\mathrm{VII}}+(2) \mathrm{T}_{\mathrm{VII}}+(3) \mathrm{T}_{\mathrm{VII}}$

TABELA 6: $\quad(1)=(1) \mathrm{T}_{\mathrm{XIV}}-338,58$

(2) $=(1) \times\left(1-(1) \mathrm{T}_{\mathrm{xIII}}\right)-37,62$

(3) $=(2) \mathrm{T}_{\mathrm{XIV}}-338,58$

$(4)=(3) \times\left(1-(2) T_{x I I I}\right)-37,62$

$(5)=(3) \mathrm{T}_{\mathrm{XIV}}-338,58$

$(6)=(5) \times\left(1-(3) \mathrm{T}_{\mathrm{XIII}}\right)-37,62$ 